\section{BIODATA PENULIS}

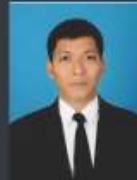

Boy Isma Putra, ST., MM. dilahirkan di Surabaya, 11 April 1974. Lulus Sarjana Teknik Industri Universitas Pembangunan Nasonal Veteran' Jawa Timur tahun 1998, melanjutkan studi S2 di Magister Manajemen Program Pascasarjana Universitas Muhammadiyah Malang lulus tahun 2004. Sejak tahun 1998 sampai sekarang, menjadi dosen tetap di prodi Teknik Industri Universitas Muhammadiyah Sidoarjo.

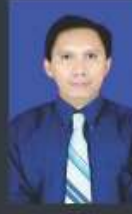

Ribangun Bamban Jakaria, ST,MM. lahir di Sidoarjo, 04 Mei 1976. Lulus Sarjana teknik Industri Universitas Muhammadiyah Sidoario tahun 2003, melanjutkan studi S2 di Magister Manajemen Program Pascasarjana Universitas Pembangunan Nasonal 'Veteran' Jawa Timur lulus tahun 2010. Saat ini sedang menempuh Program doktoral pada fakulty reka bentuk, inovasi dan teknologi Universitas Sultan Zainal Abidin (UNISZA) Kuala Terengganu Malaysia. Karir pengajaran dimulai tahun 2013 di Fakultas Sains dan Teknologi Universitas Muhammadiyah Sidoarjo. Penulis terlibat dalam penelitian dan pengabdian kepada masyarakat baik didanai oleh Ristekdikti, institusi maupun dana mandiri tentang Desain Produk, Inovasi Teknologi, Sistem Informasi dan Distribusi.

\section{PERANCANGAN SISTEM KERJA}

BOY ISMA PUTRA, ST., MM RIBANGUN BAMBAN JAKARIA, ST., MM

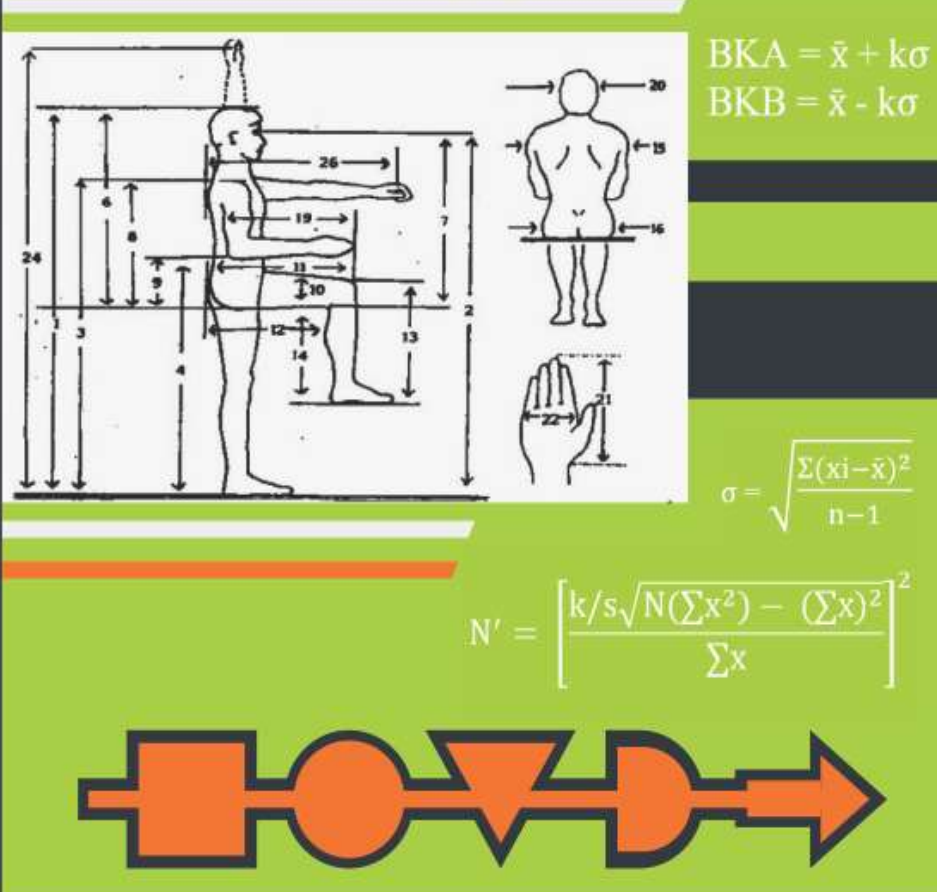

PROGRAM STUDI TEKNIK INDUSTRI FAKULTAS SAINS DAN TEKNOLOGI UNIVERSITAS MUHAMMADIYAH SIDOARJO 


\title{
BUKU AJAR \\ ANALISA DAN PERANCANGAN SISTEM KERJA
}

\author{
Oleh \\ Boy Isma Putra, ST.,MM \\ Ribangun Bamban Jakaria, ST.,MM
}

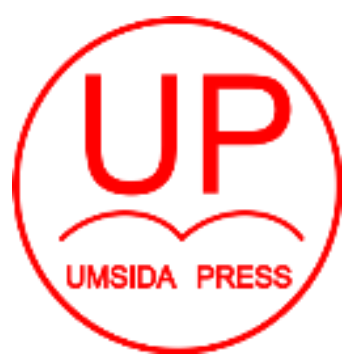

UNIVERSITAS MUHAMMADIYAH SIDOARJO

2020 
BUKU AJAR

\section{ANALISA DAN PERANCANGAN SISTEM KERJA}

\section{Penulis:}

Boy Isma Putra, ST.,MM.

Ribangun Bamban Jakaria, ST.,MM.

\section{ISBN :}

978-623-6081-01-3

\section{Editor:}

Atikha Sidhi Cahyana, ST.MT.

Design Sampul dan Tata Letak:

Mochammad Nashrullah, S.Pd.

Amy Yoga Prajati, S.Kom.

\section{Penerbit:}

UMSIDA Press

Anggota IKAPI No. 218/Anggota Luar Biasa/JTI/2019

Anggota APPTI No. 0020181092017

\section{Redaksi}

Universitas Muhammadiyah Sidoarjo

Jl. Mojopahit No 666B

Sidoarjo, Jawa Timur

Cetakan Pertama, September2020

CHak Cipta dilindungi undang undang

Dilarang memperbanyak karya tulis ini dengan sengaja, tanpa ijin tertulis dari penerbit. 


\section{KATA PENGANTAR}

Puji syukur Alhamdulillah, penulis panjatkan kepada Allah SWT, karena dengan segala rahmat, hidayah dan inayah-Nya penulis dapat menyelesaikan Buku Ajar Analisa dan Perancangan Sistem Kerja.

Sholawat serta salam penulis haturkan kepada Nabi Muhammad SAW, yang telah membimbing kita ke jalan kebenaran, keluarga, sahabat dan orang-orang yang berpegang teguh terhadap ajarannya sampai akhir zaman.

Perancangan sistem kerja merupakan suatu metode atau cara yang terdiri dari teknik-teknik dan prinsip-prinsip untuk mendapatkan rancangan terbaik dari sistem kerja yang berhubungan dengan kenyaman lingkungan kerja maupun kenyamanan pada sebuah produk yang dihasilkan dan digunakan manusia dalam memenuhi kebutuhan hidupnya. Teknik-teknik dan prinsip prinsip ini digunakan untuk mengatur komponen-komponen sistem kerja yang terdiri dari manusia dengan sifat dan kemampuannya, peralatan kerja, bahan serta lingkungan kerja sedemikian rupa sehingga dicapai tingkat efektivitas dan efisiensi yang tinggi bagi perusahaan serta aman, sehat dan nyaman bagi pekerja. Agar terciptanya sebuah kondisi kerja yang Efektif, Nyaman, Aman, Sehat, Efisien (ENASE) dapat diwujudkan.

Banyak pihak yang telah membantu dalam penyelesaian Buku Ajar ini, dan penulis menyampaikan rasa terimaksih kepada :

1. Dr. Hindarto S.Kom., MT. selaku Dekan Fakultas Sains Dan Teknologi Universitas Muhammadiyah Sidoarjo.

2. Atikha Sidhi Cahyana, ST., MT. selaku ketua Program Studi Teknik Industri Universitas Muhammadiyah Sidoarjo.

3. DR. Nurdyansyah. M.Pd selaku editor

4. Noly Shofiah, M.Pd.,M.Sc selaku editor 
5. Keluarga kecilku yang selalu mendukung penulis, special teruntuk Istriku tercinta Desita Rini Kristanti (Bunda), Muhammad Athallah Hazel Ornando (Kak Nando) dan Arthazora Boya Ornando (Dik Zora)

Dalam pelaksanaan praktek kerja lapangan ini penulis menyadari akan adanya kekurangan atau kesalahan. Akhir kata penulis semoga laporan ini bermanfaat bagi semua pihak.

Sidoarjo, Januari 2020

Penulis 


\section{DAFTAR ISI}

HALAMAN SAMPUL

IDENTITAS BUKU

KATA PENGANTAR

DAFTAR ISI

BATANG TUBUH DAN CAPAIAN PEMBELAJARAN MATA KULIAH

Halaman

BAB 1 PERAN PERANCANGAN SISTEM KERJA....................... 1

1.1. Sistem Produksi................................................... 1

1.1.1. Input............................................................... 2

1.1.2. Proses.................................................. 5

1.1.3. Output................................................... 6

1.2. Produktivitas................................................... 8

1.3. Elemen-elemen Produktivitas................................ 9

1.4. Perhitungan Produktivitas.................................. 10

BAB 2 SISTEM KERJA MANUSIA DENGAN MESIN................... 14

2.1. Peta Kerja.......................................................... 14

2.2. Simbol-simbol Standar Pembuatan Peta Kerja......... 15

2.3. Macam-macam Peta Kerja.................................. 17

2.3.1. Peta Kerja Keseluruhan................................ 18

2.3.1.1. Peta Proses Operasi........................ 18

2.3.1.2. Peta Aliran Proses.......................... 22

2.3.1.3. Diagram Aliran Proses...................... 25

2.3.1.4. Peta Proses Kelompok Kerja............ 28

2.3.2. Peta Kerja Setempat................................... 29

2.3.2.1. Peta Pekerja dan Mesin.................. 30

2.3.2.2. Peta Tangan Kiri dan Tangan Kanan.. 32

BAB 3 PENGUKURAN WAKTU KERJA.................................. 38

3.1 Pengukuran Waktu Kerja.................................... 38

3.2 Uji Kecukupan Data............................................ 39

3.3 Uji Keseragaman Data...................................... 40 
3.4 Performance Rating......................................... 41

3.4.1. Westing House System's Rating................... 42

3.4.2. Schumard................................................ 43

3.5 Kelonggaran (Allowance).................................... 44

3.6 Waktu Siklus..................................................... 45

3.7 Waktu Normal.................................................. 46

3.8 Waktu Baku........................................................ 47

3.9 Output Standard................................................. 48

BAB 4 SISTEM KERJA MANUSIA DAN MESIN........................ 50

4.1. Sistem Hubungan Manusia dan Mesin....................... 50

4.1.1. Sistem Manusia Mesin Secara Manual.............. 50

4.1.2. Sistem Manusia Mesin Secara Semi Autimatic... 51

4.1.3. Sistem Manusia Mesin Secara Automatic.......... 52

4.1.4. Kondisi Lingkungan Kerja.................................. 54

4.1.4.1. Suhu...................................................... 54

4.1.4.2. Kelembapan Udara.................................. 55

4.1.4.3. Sirkulasi Udara.............................................. 55

4.1.4.4. Pencahayaan............................................ 56

4.1.4.5. Kebisingan............................................... 56

4.1.4.6. Getaran Mekanis.......................................... 56

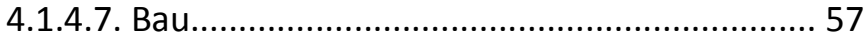

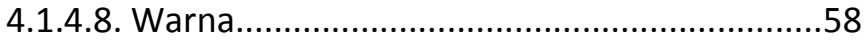

\section{BAB 5 ALAT PERAGA/DISPLAY DAN SISTEM PENGENDALIAN}

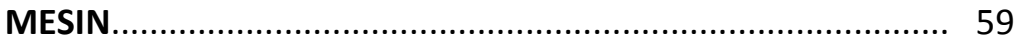

5.1. Pengaturan Informasi...................................... 59

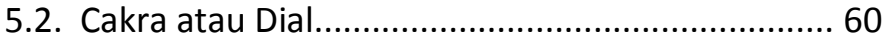

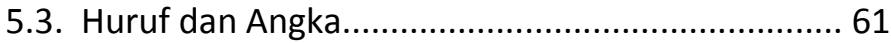

5.4. Tipe Pengendalian Mesin..................................... 62

5.5. Pengendalian Pekerjaan Ringan............................ 63 
BAB 6 METODE SAMPLING KERJA (WORK SAMPLING)............66

6.1. Metode Work Sampling .............................................. 66

6.2. Tabel Bilangan Acak.................................................. 67

6.3. Menentukan Jumlah Pengamatan......................................69

6.4. Uji Kecukupan Data..........................................................70

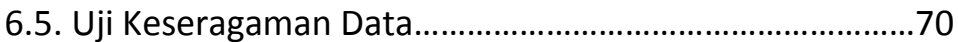

6.6. Perhitungan Waktu Baku.................................................72

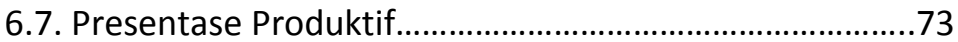

6.8. Presentase Non-Produktif............................................ 73

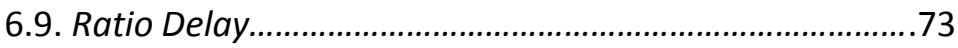

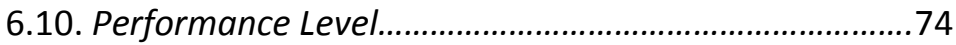

6.11. Jumlah Menit Produktif (JMP) .......................................74

6.12. Penentuan Besaran Satuan Waktu............................... 74

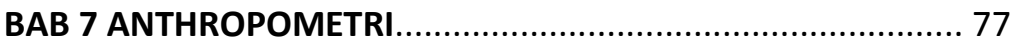



7.2. Faktor-faktor yang Mempengaruhi Data

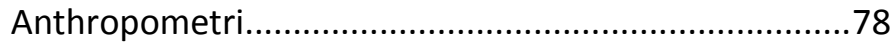

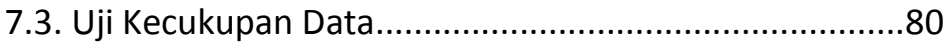

7.4. Uji Keseragaman Data............................................. 81

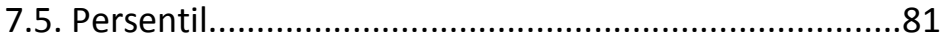

7.6. Data Anthropometri yang Diperlukan Untuk Perancangan Produk /Fasilitas Kerja............................ 82

\section{BAB 8 STUDI EKONOMI GERAKAN}

(MICROMOTION STUDY)...........................................86

8.1. Pengertian Studi Gerakan...................................... 86

8.2. Prinsip Ekonomi Gerakan........................................... 87

8.3. Peta Tangan Kanan Tangan Kiri................................ 88

8.4.Gerakan Fundamental (Therblig's)........................... 88

BAB 9 Lingkungan Kerja Fisik ................................................. 97

9.1. Pengertian Lingkungan Kerja...................................97

9.2. Jenis Lingkungan Kerja............................................97

9.2.1. Lingkungan Kerja Fisik....................................98 
9.2.2. Lingkungan Kerja Non Fisik. .98

9.3. Faktor-Faktor Yang Mempengaruhi Lingkungan

Kerja Fisik. 99

9.4. Regresi Linier 111

9.5. Hasil Uji Linier Regression dengan Software SPSS........120

BAB 10 BIOMEKANIKA 121

10.1. Pengertian Biomekanika...........................................121

10.2. Sistem Kardiovaskular................................................122

10.3. Pengukuran Fisiologis........................................... 124

10.3.1. Kebutuhan Waktu Istirahat....................................125

10.3.2. Metode Casdioviscular Load................................. 127

10.3.3. Hubungan Denyut Jantung dengan Energi Expenditur (Kuantitatif)....................................... 128

10.4. Hubungan denyut jantung dengan energi expenditure (SPSS).

BAB 11 BEBAN KERJA (WORK LOAD)...................................138

11.1. Faktor yang Mempengaruhi Beban Kerja...................139

11.1.1. Beban Kerja Karena Faktor Eksternal................139

11.1.2. Beban Kerja Karena Faktor Internal.................. 140

11.2. Penilaian Bebas Kerja Fisik........................................... 141

11.3. Penilaian Beban Kerja Berdasarkan Jumlah Kebutuhan Kalori.

\section{BAB 12 ANALISA PERANCANGAN KURSI KULIAH YANG}

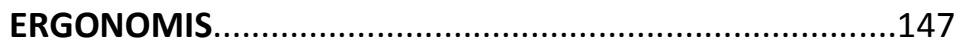

12.1. Data Hasil Pengamatan...........................................147

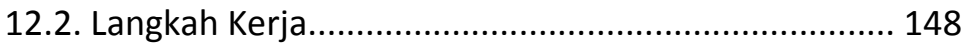

12.3. Pengolahan Data.................................................. 148

12.3.1. Pengukuran Tinggi Duduk Tegak (TDT)...........148

12.3.2. Pengukuran Jangkauan Tangan Depan (JTD).. 153

12.3.3. Pengukuran Lebar Bahu (LB).........................157

12.3.4. Pengukuran Panjang Tangan (PT)................. 161

12.4. Analisis Data...................................................... 165 
BAB 13 PENERAPAN STUDY EKONOMI GERAKAN (MICROMOTION STUDY) GUNA MENGEFESIENKAN

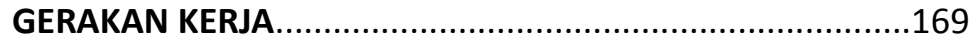

13.1. Studi Gerakan Untuk Menganalisa Metode Kerja........169

13.2. Gerakan Fundamental Untuk Pelaksanaan Kerja Manual.......................................................................170

13.3. Peta Tangan Kiri dan Tangan Kanan..............................172

13.4. Data Hasil Pengamatan..............................................173

13.5. Data Hasil Pengamatan Material dengan Peletakan Tidak Beraturan.....................................................173

13.6. Data Hasil Pengamatan Material dengan Peletakan Beraturan.......................................................................179

13.7. Perakitan Mobil Lego Secara Tidak Beraturan............ . 183

13.7.1. Hasil Analisa Peta Tangan Kiri..........................183

13.7.2. Hasil Analisa Peta Tangan Kanan.......................184

13.8. Perakitan Mobil Lego Secara Beraturan.......................184

13.8.1. Hasil Analisa Peta Tangan Kiri.......................... 185

13.8.2. Hasil Analisa Peta Tangan Kanan......................186

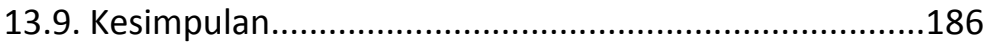

DAFTAR PUSTAKA

BIODATA PENULIS 
BATANG TUBUH DAN

SUB-CAPAIAN PEMBELAJARAN MATA KULIAH

\begin{tabular}{|c|c|}
\hline BAB & Sub-Capaian Pembelajaran Mata Kuliah \\
\hline $\begin{array}{l}\text { BAB } 1 \\
\text { SISTEM PRODUKSI } \\
\text { DAN } \\
\text { PRODUKTIVITAS }\end{array}$ & $\begin{array}{l}\text { 1. Memberikan pemahaman kepada mahasiswa } \\
\text { tentang konsep produksi dan produktivitas } \\
\text { 2. Mahasiswa dapat menghitung besarnya nilai } \\
\text { produktivitas produksi perusahaan pada periode } \\
\text { waktu tertentu } \\
\text { 3. Mahasiswa dapat menghitung besarnya nilai } \\
\text { produktivitas perusahaan, baik produktivitas total } \\
\text { maupun parsial. }\end{array}$ \\
\hline $\begin{array}{l}\text { BAB } 2 \\
\text { PETA KERJA }\end{array}$ & $\begin{array}{l}\text { Melatih kemampuan dalam membuat peta - peta } \\
\text { kerja atas suatu sistem produksi beserta symbol- } \\
\text { symbol menurut ASME (American Society of } \\
\text { Mechanical Engineering). } \\
\text { Melatih kemampuan dengan menggunakan peta } \\
\text { - peta kerja dalam mengidentifikasikan } \\
\text { permasalahan yang ada, dan berbagai alat } \\
\text { analisis perbaikan sistem kerja dengan } \\
\text { menggunakan metode Dot and Check Tehnique. } \\
\text { Mampu membedakan jenis peta kerja antara } \\
\text { Peta Kerja Analisa Setempat dan Peta Kerja } \\
\text { Analisa Keseluruhan. }\end{array}$ \\
\hline $\begin{array}{l}\text { BAB } 3 \\
\text { PENGUKURAN } \\
\text { WAKTU KERJA }\end{array}$ & $\begin{array}{l}\text { 1. Mahasiswa mampu menentukan kecukupan dan } \\
\text { keseragaman data. } \\
\text { 2. Mahasiswa mampu menentukan besarnya } \\
\text { performance rating dan nilai kelonggaran. } \\
\text { 3. Mahasiswa dapat dan mampu menghtiung Waktu } \\
\text { Siklus, Waktu Normal, Waktu Baku dan Output } \\
\text { Standar }\end{array}$ \\
\hline BAB 4 & $\begin{array}{l}\text { 1. Mahasiswa mampu memahami konsep Sistem kerja } \\
\text { manual, system kerja semi otomatis dan system }\end{array}$ \\
\hline
\end{tabular}




\begin{tabular}{|c|c|}
\hline $\begin{array}{l}\text { SISTEM KERJA } \\
\text { MANUSIA DAN } \\
\text { MESIN }\end{array}$ & $\begin{array}{l}\text { kerja full otomatis. } \\
\text { 2. Mahasiswa mampu mengidentifikasi perbedaan } \\
\text { manusia dengan mesin. } \\
\text { 3. Mahasiswa dapat mengidentifikasi faktor-faktor } \\
\text { yang mempengaruhi produktivitas kerja }\end{array}$ \\
\hline $\begin{array}{l}\text { BAB } 5 \\
\text { ALAT } \\
\text { PERAGA/DISPLAY } \\
\text { DAN SISTEM } \\
\text { PENGENDALIAN } \\
\text { MESIN }\end{array}$ & $\begin{array}{l}\text { 1. Mahasiswa memahami jenis-jenis pembaca display } \\
\text { 2. Mahasiswa dapat menemukan kelebihan dan } \\
\text { kekurangan dari macam alat pembaca display } \\
\text { 3. Mahasiswa dapat menentukan besarnya huruf dan } \\
\text { angka yang sesuai dengan jarak baca. }\end{array}$ \\
\hline $\begin{array}{l}\text { BAB } 6 \\
\text { METODE } \\
\text { SAMPLING KERJA }\end{array}$ & $\begin{array}{l}\text { 1. Mahasiswa dapat menghitung besaran nilai bilangan } \\
\text { satuan berdasarkan kelompok angka pada tabel } \\
\text { bilangan acak yang dipilih } \\
\text { 2. Mahasiswa dapat membuat dan menentukan waktu } \\
\text { kunjungan pengambilan sampel } \\
\text { 3. Mahasiswa dapat menganalisa produktivitas kerja } \\
\text { dan idle pada suatu shift kerja }\end{array}$ \\
\hline $\begin{array}{l}\text { BAB } 7 \\
\text { ANTHROPOMETRI }\end{array}$ & $\begin{array}{l}\text { 1. Mahasiswa dapat membuat suatu perancangan } \\
\text { fasilitas yang ergonomis agar pengguna merasa } \\
\text { nyaman dan puas. } \\
\text { 2. Mahasiswa dapat menciptakan desain manusia } \\
\text { mesin yang terpadu sehingga efektifitas dan } \\
\text { effisiensi kerja bisa tercapai secara optimal. } \\
\text { 3. Mahasiswa dapat menggunakan suatu perancangan } \\
\text { peralatan kerja (tools) untuk penggunaan yang lebih } \\
\text { efektif. } \\
\text { 4. Sebagai upaya untuk memperbaiki performans kerja } \\
\text { manusia seperti menambah kecepatan kerja, } \\
\text { accuracy, keselamatan kerja, mengurangi energi } \\
\text { kerja yang berlebihan dan mengurangi datangnya } \\
\text { kelelahan yang terlalu cepat. } \\
\text { 5emperbaiki pendayagunaan sumber daya manusia }\end{array}$ \\
\hline
\end{tabular}




\begin{tabular}{|c|c|}
\hline & $\begin{array}{l}\text { serta meminimalkan kerusakan peralatan yang } \\
\text { disebabkan kesalahan manusia. }\end{array}$ \\
\hline $\begin{array}{l}\text { BAB } 8 \\
\text { STUDY EKONOMI } \\
\text { GERAKAN }\end{array}$ & $\begin{array}{l}\text { 1. Mahasiswa mampu mengamati elemen-elemen } \\
\text { kerja yang dibutuhkan dalam satu pekerjaan } \\
\text { spesifik. } \\
\text { 2. Mahasiswa mampu memilih atau membagi suatu } \\
\text { pekerjaan atas elemen-elemen gerakan. } \\
\text { 3. Mahasiswa mampu melakukan perancangan dan } \\
\text { perbaikan suatu sistem kerja dengan menggunakan } \\
\text { prinsip-prinsip ekonomi gerakan dan symbol } \\
\text { Therbligh. }\end{array}$ \\
\hline $\begin{array}{l}\text { BAB } 9 \\
\text { LINGKUNGAN } \\
\text { KERJA FISIK }\end{array}$ & $\begin{array}{l}\text { 1. Memahami dan mampu menganalisa adanya faktor } \\
\text { - faktor lingkungan yang mempengaruhi } \\
\text { performansi kerja seseorang. } \\
\text { 2. Memahami adanya suatu kondisi optimum dalam } \\
\text { melakukan suatu aktivitas kerja. } \\
\text { 3. Dapat memanfaatkan metode statistik untuk } \\
\text { digunakan dalam menganalisa performansi kerja. }\end{array}$ \\
\hline $\begin{array}{l}\text { BAB } 10 \\
\text { BIOMEKANIKA }\end{array}$ & $\begin{array}{l}\text { 1. Memahami dan mampu menganalisa adanya faktor- } \\
\text { faktor fisiologis dan lingkungan yang mempengaruhi } \\
\text { performansi kerja seseorang. } \\
\text { 2. Memahami adanya suatu kondisi optimum dan } \\
\text { melakukan sesuatu aktivitas kerja. } \\
\text { 3. Dapat melakukan salah satu teknik pengukuran } \\
\text { aktivitas faal kerja, yaitu pengukuran konsumsi } \\
\text { energi dalam suatu kerja. } \\
\text { 4. Mengetahui pengaruh perbedaan kecepatan dan } \\
\text { sudut kemiringan tangga terhadap konsumsi energi } \\
\text { manusia yang beraktivitas diatasnya. }\end{array}$ \\
\hline BAB 11 & 1. Mahasiswa memahami faktor-faktor yang \\
\hline
\end{tabular}




\begin{tabular}{|c|c|}
\hline $\begin{array}{l}\text { BEBAN KERJA } \\
\text { (WORK LOAD) }\end{array}$ & $\begin{array}{l}\text { mempengaruhi beban kerja. } \\
\text { 2. Mahasiswa mengetahui berbagai tingkatan beban } \\
\text { kerja beserta pengukuran fisiologisnya } \\
\text { 3. Mahasiswa memahami kebutuhan kalori tubuh } \\
\text { manusia }\end{array}$ \\
\hline $\begin{array}{l}\text { BAB } 12 \\
\text { ANALISA } \\
\text { PERANCANGAN } \\
\text { KURSI KULIAH } \\
\text { YANG } \\
\text { ERGONOMIS }\end{array}$ & $\begin{array}{l}\text { 1. Mahasiswa memahami penerapan perhitungan } \\
\text { anthropometri untuk merancang kursi kuliah yang } \\
\text { sesuai dengan data. } \\
\text { 2. Mahasiswa memahami cara pengukuran dimensi } \\
\text { tubuh. }\end{array}$ \\
\hline $\begin{array}{l}\text { BAB } 13 \\
\text { PENERAPAN } \\
\text { STUDY EKONOMI } \\
\text { GERAKAN } \\
\text { (MICROMOTION } \\
\text { STUDY) GUNA } \\
\text { MENGEFISIENKAN } \\
\text { GERAKAN KERJA }\end{array}$ & $\begin{array}{l}\text { 1. Mahasiswa mampu menganalisa jenis gerakan } \\
\text { menurut symbol Therbligh. } \\
\text { 2. Mahasiswa dapat menghitung jumlah dan waktu } \\
\text { gerakan kondisi kerja pada dua kondisi yang } \\
\text { berbeda. }\end{array}$ \\
\hline
\end{tabular}




\section{BAB 1.}

\section{SISTEM PRODUKSI DAN PRODUKTIVITAS}

\subsection{Sistem Produksi}

Banyak cara yang telah dilakukan manusia untuk memenuhi kebutuhan hidupnya sebagai salah satu upaya untuk dapat bertahan hidup (survival). Salah satu upaya tersebut adalah dengan cara merubah atau mengolah sumber-sumber produksi (6M) yang berfungsi sebagai bahan masukan (input) menjadi sebuah hasil luaran (output), yang mana luaran tersebut dapat berbentuk Barang produksi atau jasa.

Untuk keluaran barang produksi dapat berbentuk bahan setengah jadi (intermediate goods) atau bahan jadi (finished goods) yang siap dipakai atau digunakan.

Kagiatan yang dilakukan manusia untuk merubah sumber-sumber produksi menjadi hasil luaran, baik berbentuk barang produksi atau jasa disebut dengan produksi. Kegiatan produksi dapat diilustrasikan pada gambar 1.1 dibawah ini: 


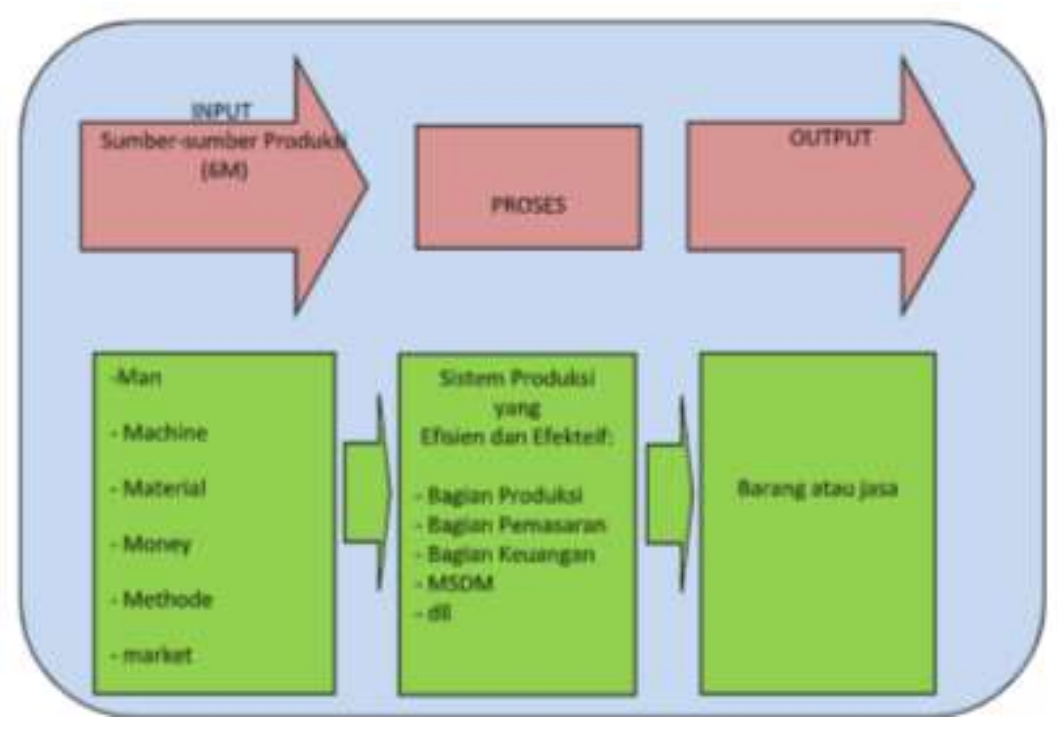

Gambar 1.1 Konsep Produksi

\subsubsection{Input}

Input atau masukan dapat diartikan sebagai bahan dasar atau bahan baku yang akan diolah lebih lanjut untuk menghasilkan sebuah hasil luaran. Input atau masukan yang akan diolah dapat juga disebut sebagai sumber-sumber produksi yang meliputi :

$>$ Man (Manusia)

Dalam system produksi membutuhkan adanya peranan atau campur tangan manusia sebagai tenaga kerja didalamnya. Faktor manusia merupakan faktor atau unsure terpenting yang menjadi pokok perhatian pada bidang ilmu ergonomi, mengapa? Karena manusia akan 
dapat bekerja secara maksimal dan memiliki tingkat produktivitas yang baik jika tercipta rasa kenyamanan antara manusia dengan lingkungan kerjanya.

Disamping itu diharapkan pula unsure manusia dapat memiliki dan memenuhi satndarisasi ketrampilan (kualifikasi) yang sesuai dengan bidang kerjanya, agar produk atau keluaran yang dihasilkan memiliki mutu yang baik.

$>$ Machine (Mesin)

Mesin adalah sumber produksi yang secara teknis berbentuk sebuah mesin beserta dengan peralatan (tools) pendukungnya yang dapat mengubah sebuah bahan baku mentah (raw materials) menjadi luaran sebuah produk manufaktur. Agar mesin dapat menghasilkan hasil luaran dengan mutu dan kualitas yang baik, tentunya performa dari mesin tersebut harus selalu dijaga dan ditingkatkan. Salah satu cara untuk menjaga kualitas produk yang dihasilkan, maka perawatan berkala (preventive maintenance) diharapkan dapat dijalankan dengan baik dan dilakukan secara teratur.

Material (bahan baku produk mentah)

Material merupakan bahan baku mentah yang akan diubah untuk menghasilkan sebuah hasil keluaran 
(output), baik berbentuk produk manufaktur maupun jasa. Diharapkan kualitas bahan baku yang akan digunakan harus selalu diperhatikan, karena walaupun proses pengerjaannya sudah dilakukan dengan baik dan sesuai dengan standard pengerjaan yang telah ditentukan, namun jika kualitas bahan mentah yang digunakan jelek, maka hasil akhir keluaran yang dihasilkan akan jelek pula.

$>$ Money (uang)

Uang merupakan sumber produksi yang berbentuk sebuah sarana pembayaran dalam bentuk uang. Dengan uang atau modal ini perusahaan dapat membeli segala keperluan produksi, membayar gaji pegawai, cicilan hutang di bank, dan lain-lain dengan lancar.

$>$ Methode (Metode/cara)

Metode dapat diartikan sebagai sebuah cara kerja atau serangkaian prosedur yang harus dilakukan dalam proses produksi, agar produk luaran yang dihasilkan sesuai dengan kualitas dan fungsi yang diinginkan. Sebaiknya perusahaan senantiasa selalu mengikuti perkembangan ilmu atau cara yang terbaru (uptodate).

Market (Pasar).

Pasar merupakan wilayah penyerapan dari produk luaran yang dihasilkan. Sebaiknya sebelum produk 
dibuat perusahaan telah melakukan riset penelitian pasar tentang sebuah produk. Mulai dari kelas pasar (segment) mana yang akan diraih. Secara garis besar kelas pasar dibagi menjadi 3, yaitu: kelas pasar tertinggi (high end), kelas pasar sedang (middle end) dan kelas pasar bawah (low end); fitur-fitur yang diinginkan, harga, kualitas, saluran distribusi, garansi, service, dll, agar produk yang dibuat sesuai dengan kemampuan dan selera konsumen, sehingga diharapkan produk perusahaan dapat terserap melalui pembelian dengan baik.

Sumber-sumber produksi diatas saling terkait satu dengan lainnya dan tidak dapat berdiri sendiri secara parsial.

\subsubsection{Proses}

Proses Produksi adalah sebuah proses transformasi dalam sistem produksi yang bertujuan untuk mengolah sumbersumber produksi (6M) yang terdiri atas: tenaga kerja (man), mesin (machine), dana keuangan (money), material (materials), metode kerja (method), dan pasar (market), dalam suatu lingkungan guna menghasilkan nilai tambah bagi produk agar dapat dijual dengan harga kompetitif di pasar. Proses produksi yang baik adalah sebuah proses produksi yang mengacu pada efektivitas dan efisiensi. Artinya sebaiknya sebuah proses produksi didasarkan pada 
efektivitas penentuan jumlah tenaga kerja yang sesuai dengan kebutuhan produksi dan efisiensi waktu.

\subsubsection{Output}

Output merupakan hasil keluaran yang dihasilkan oleh sebuah proses produksi dalam mengolah sumber-sumber produksi yang dapat berbentuk barang manufaktur atau jasa.

Output yang baik adalah sebuah hasil keluaran yang memiliki kualitas yang baik dan kuantitas yang maksimal dan memiliki harga yang sesuai. Adapun beberapa contoh hasil luaran sebuah system produksi dapat dilihat pada Tabel 1.1 dibawah ini:

Tabel 1.1. Contoh Hasil Luaran Sistem Produksi

\begin{tabular}{|c|c|l|l|c|}
\hline No & Sistem & \multicolumn{1}{|c|}{ Input } & Output & $\begin{array}{c}\text { Jenis } \\
\text { Output }\end{array}$ \\
\hline \multirow{2}{*}{1} & \multirow{2}{*}{ Universitas } & $\begin{array}{l}\text { Yayasan, } \\
\text { Rektorat, } \\
\text { Dosen, } \\
\text { Tenaga } \\
\text { Admin, } \\
\text { Mahasiswa, } \\
\text { Orang tua } \\
\text { Mahasiswa, } \\
2\end{array}$ & $\begin{array}{l}\text { Mahasiswa } \\
\text { yang } \\
\text { Derkompeten }\end{array}$ & Jasa \\
\hline \multirow{2}{*}{ Bank } & $\begin{array}{l}\text { Pemilik } \\
\text { saham, } \\
\text { Pimpinan } \\
\text { bank, }\end{array}$ & Kelayanan & Jasa \\
\hline
\end{tabular}




\begin{tabular}{|c|c|c|c|c|}
\hline & & $\begin{array}{l}\text { karyawan, } \\
\text { tenaga } \\
\text { keamanan, } \\
\text { investor, } \\
\text { nasabah }\end{array}$ & & \\
\hline 3 & $\begin{array}{c}\text { Rumah } \\
\text { Sakit }\end{array}$ & $\begin{array}{l}\text { Pimpinan, } \\
\text { Tenaga } \\
\text { Admin, } \\
\text { Tenaga } \\
\text { Medis, } \\
\text { Tenaga } \\
\text { Keamanan, } \\
\text { perusahaan } \\
\text { farmasi, } \\
\text { pasien }\end{array}$ & $\begin{array}{l}\text { Pelayanan } \\
\text { Kesehatan }\end{array}$ & Jasa \\
\hline 4 & $\begin{array}{l}\text { Bisnis } \\
\text { Online }\end{array}$ & $\begin{array}{l}\text { Karyawan, } \\
\text { pimpinan, } \\
\text { pembuat } \\
\text { produk, } \\
\text { konsumen, } \\
\text { vendor } \\
\text { internet, } \\
\text { konsumen, } \\
\text { komunitas }\end{array}$ & $\begin{array}{l}\text { Pelayanan } \\
\text { Pembelian } \\
\text { barang }\end{array}$ & Jasa \\
\hline 5 & Pabrik & $\begin{array}{l}\text { Pimpinan, } \\
\text { karyawan, } \\
\text { manajer, } \\
\text { keamanan, } \\
\text { distributor, } \\
\text { konsumen }\end{array}$ & $\begin{array}{l}\text { Produk } \\
\text { Manufaktur }\end{array}$ & $\begin{array}{c}\text { Produk } \\
\text { manufaktur }\end{array}$ \\
\hline
\end{tabular}




\subsection{Produktivitas}

Produktivitas dapat diartikan sebagai pembagian atau rasio antara Output dengan Input. Produktivitas merupakan salah satu tolok ukur yang digunakan untuk mengevaluasi keberhasilan kerja suatu organisasi atau perusahaan.

Produktivitas merupakan Rasio output dengan tenaga kerja (man), mesin (machine), dana keuangan (money), material (materials), metode kerja (method), dan pasar (market).

Kesadaran akan peningkatan produktivitas semakin meningkat karena adanya suatu keyakinan bahwa perbaikan produktivitas akan memberikan kontribusi positif dalam perbaikan ekonomi. Pandangan bahwa kehidupan hari ini harus lebih baik dari kehidupan hari kemarin dan kehidupan hari esok harus lebih dari hari ini, merupakan suatu pandangan yang memberi dorongan pemikiran ke arah produktivitas.

Manfaat positif apakah yang bisa dicapai dengan terjadinya peningkatan produktivitas dari suatu aktivitas produksi, agar bisa memberikan suatu ilustrasi yang jelas dapat dilihat pada gambar 1.2 dibawah 


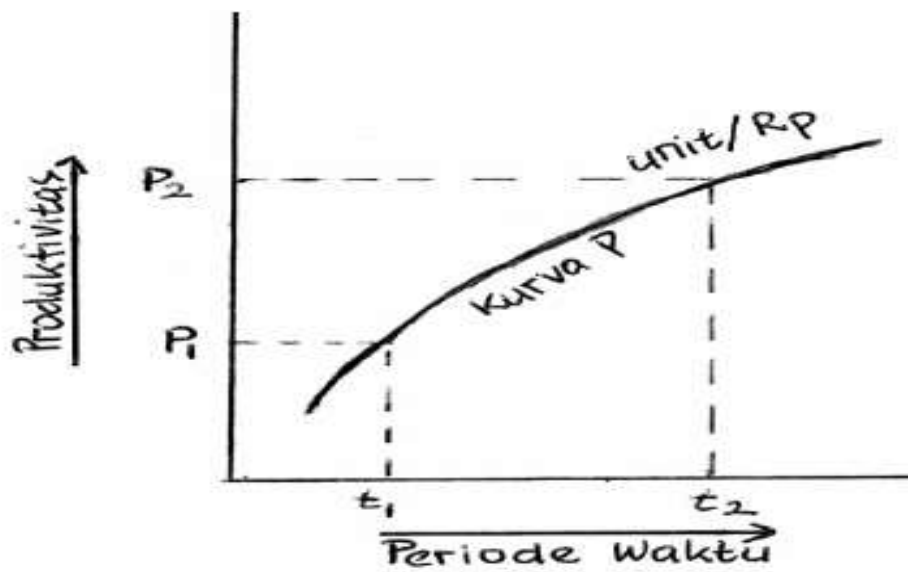

Gambar 1.2 Kurva Kenaikan Produktivitas

\subsection{Elemen-elemen Produktivitas}

Elemen produktivitas secara garis besar kita bagi menjadi dua (2), yaitu elemen non teknis dan elemen teknis. Adapun elemen tersebut sebagai berikut:

Elemen non teknis : tenaga kerja (man)

Elemen teknis : mesin (machine)

Dana keuangan (money)

Material (materials)

Metode kerja (method)

Pasar (market) 


\subsection{Perhitungan Produktivitas}

Untuk mengetahui baik dan buruknya prsetasi kerja (kinerja) suatu perusahaan dapat dilihat dari capaian produktivitasnya. Untuk dapat menyimpulkan sebuah produktivitas dikatakan baik atau buruk, perusahaan harus membandingkan hasil perhitungan produktivitas suatu periode tertentu dengan periode lainnya. Jika capaian hasil perhitungan produktivitas yg dihitung dan dibandingkan dengan suatu periode tertentu mengalami peningkatan, maka kinerja perusahaan tersebut meningkat dan jika sebaliknya maka kinerja perusahaan tersebut menurun.

Rumus produktivitas secara umum dapat dilihat dibawah ini:

Produktivitas $(\mathrm{P})=\frac{\text { output }}{\text { Input }}$

Adapun cara menghitung produktivitas sebuah perusahaan dapat dibedakan menjadi tiga (3) jenis, yaitu:

a. Perhitungan Produktivitas Parsial Perhitungan produktivitas ini merupakan rasio antara output dengan salah satu faktor dari sumber-sumber produksi $(6 \mathrm{M})$, seringkali disebut juga perhitungan produktivitas tunggal. 


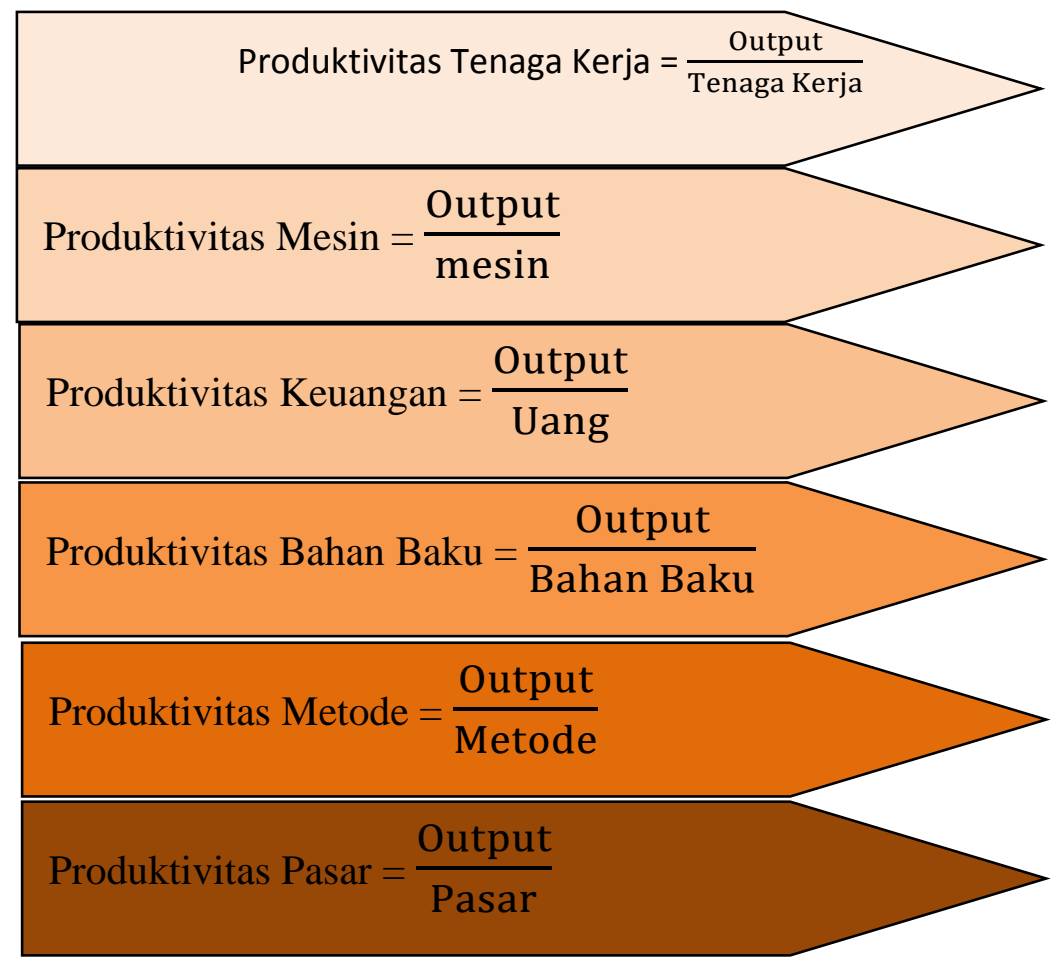

b. Perhitungan Produktivitas Multi Faktor

Perhitungan produktivitas ini merupakan rasio antara output dengan gabungan beberapa faktor-faktor produksi.

$$
\text { Produktivitas }=\frac{\text { Output }}{\text { Tenaga Kerja }+ \text { Mesin }}
$$




$$
\text { Produktivitas }=\frac{\text { Output }}{\text { Tenaga Kerja }+ \text { Mesin+Finansial }}
$$

Produktivitas $=\frac{\text { Output }}{\text { Mesin+Finansial+Bahan Baku }}$

c. Perhitungan Produktivitas Total

Perhitungan produktivitas ini merupakan rasio antara output dengan seluruh faktor-faktor produksi yang dimiliki oleh perusahaan.

Produktivitas

Contoh soal

1. Informasi Produksi Perusahaan "PT. X"sebagai berikut:

Pada Bulan Januari 2020 menghasilkan output produk manufaktur sebesar 500 unit. Adapun Tenaga Kerja yang dipekerjakan sebanyak 8 orang dengan jam kerja sehari selama 8 jam produktif. Bahan baku yang dibutuhkan sebanyak 1000 ton. Hari kerja efektif pada Bulan Januari 2020 sebanyak 25 hari.

Sedangkan pada Bulan Pebruari 2020 menghasilkan output produk manufaktur sebesar 700 unit. Adapun Tenaga Kerja yang digunakan 
sebanyak 8 orang dengan jam kerja sehari selama 8 jam produktif. Bahan baku yang dibutuhkan sebanyak 1200 ton. Hari kerja efektif pada Bulan Januari 2020 sebanyak 20 hari.

Hitunglah Besarnya nilai Produktivitas "PT. X" dan berikan kesimpulan!

2. Dari pengamatan pengukuran kerja pada pabrik keramik di PT. Jongos, didapatkan data pengamatan langsung waktu baku 2,5 menit/keramik. Diketahui upah dasar per jam adalah Rp. 5.750. Bila saudara sebagai pemborong, dan mempunyai 7 orang pekerja yang prestasinya seperti pada tabel dibawah ini, maka berapakah gaji yang saudara berikan pada masing-masing tukang.

\begin{tabular}{|c|c|c|}
\hline Tukang & Output/jam & Gaji/jam \\
\hline Unyil & 30 & \\
\hline Usrok & 35 & \\
\hline Cuplis & 50 & \\
\hline Ucrit & 45 & \\
\hline Kinoi & 55 & \\
\hline Ciner & 40 & \\
\hline Bejo & 50 & \\
\hline
\end{tabular}




\section{BAB. 2}

\section{PETA KERJA}

\subsection{Peta Kerja}

Menurut Maryana (2015), peta kerja adalah suatu alat yang menggambarkan kegiatan kerja secara sistematis dan jelas. Lewat peta-peta ini kita bisa melihat semua langkah atau kejadian yang dialami oleh suatu benda kerja dari mulai masuk ke pabrik (berbentuk bahan baku), kemudian menggambarkan semua langkah yang dialaminya, seperti: transportasi, operasi mesin, pemeriksaan dan perakitan, sampai akhirnya menjadi produk jadi, baik produk lengkap atau merupakan bagian dari suatu produk lengkap.

Ada pula defenisi peta kerja lainnya yaitu merupakan gambaran sistematis dan logis dalam menganalisis proses kerja dari tahap awal sampai akhir. Dengan peta ini juga didapatkan informasiinformasi yang diperlukan untuk memperbaiki metode kerja, seperti benda kerja yang harus dibuat, operasi untuk menyelesaikan kerja, kapasitas mesin atau kapasitas kerja lainnya, dan urutan prosedur kerja yang dialami oleh suatu benda kerja. Dengan demikian, peta ini merupakan alat yang baik untuk menganalisa suatu pekerjaan sehingga mempermudah dalam perencanaan perbaikan kerja. 


\subsection{Simbol - Simbol Standar Pembuatan Peta Kerja}

Menurut catatan sejarah, peta-peta kerja yang ada sekarang ini dikembangkan oleh Gilberth. Pada saat itu, untuk membuat suatu peta kerja, Gilberth mengusulkan 40 buah lambang yang bisa dipakai. Pada tahun berikutnya jumlah lambang tersebut disederhanakan sehingga hanya tinggal 4 macam saja. Namun pada tahun 1947 American Society of Mechanical Engineers (ASME) membuat standar lambang-lambang yang terdiri atas 5 macam lambang yang merupakan modifikasi dari yang telah dikembangkan sebelumnya oleh Gilberth. Lambang-lambang tersebut dapat diuraikan sebagai berikut (Maryana,2015):

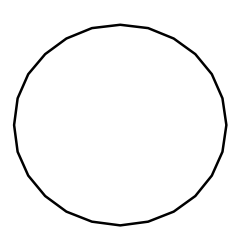

Operasi, Suatu kegiatan operasi terjadi apabila benda kerja mengalami perubahan sifat, baik fisik maupun kimiawi. Mengambil informasi maupun menberikan informasi pada suatu keadaan juga termasuk operasi. Operasi merupakan kegiatan yang paling banyak terjadi dalam suatu mesin atau sistem kerja. Contohnya : Pekerjaan menyerut kayu dengan mesin serut, Pekerjaan mengeraskan logam, dan Pekerjaan merakit. Dalam prakteknya, lambang ini juga bisa digunakan untuk menyatakan aktivitasadministrasi.

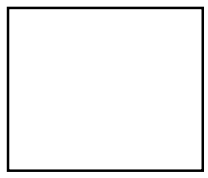

Pemeriksaan, Suatu kegiatan pemeriksaan terjadi apabila benda kerja atau peralatan mengalami pemeriksaan baik untuk segi kualitas maupun kuantitas. Lambang ini digunakan jika kita melakukan pemeriksaan 
terhadap suatu objek atau membandingkan objek tertentu dengan suatu standar. Suatu pemeriksaan tidak menjuruskan bahan kearah menjadi suatu barang jadi. Contohnya : Mengukur dimensi benda, Memeriksa warna benda, dan Membaca alat ukur tekanan uap pada suatu mesin uap.

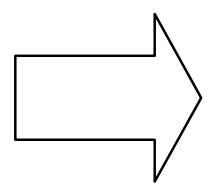

Transportasi, Suatu kegiatan transportasi terjadi apabila benda kerja, pekerja atau perlengkapan mengalami perpindahan tempat yang bukan merupakan bagian dari suatu operasi. Contohnya : Benda kerja diangkut dari mesin bubut ke mesin skrap untuk mengalami operasi berikutnya, suatu objek dipindahkan dari lantai atas lewat elevator.

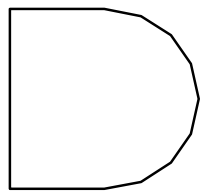

Menunggu, Proses menunggu terjadi apabila benda kerja, pekerja ataupun perlengkapan tidak mengalami kegiatan apa-apa selain menunggu (biasanya sebentar). Contohnya : Objek menunggu untuk diproses atau diperiksa, peti menunggu untuk dibongkar, dan bahan menunggu untuk diangkut ke tempat lain.

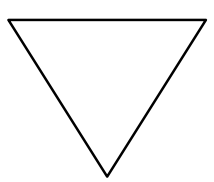

Penyimpanan, Proses penyimpanan terjadi apabila benda kerja di simpan untuk jangka waktu yang cukup lama. Lambang ini digunakan untuk menyatakan suatu objek yang mengalami penyimpanan permanen, yaitu ditahan atau dilindungi terhadap pengeluaran tanpa izin tertentu. Contohnya : Dokumen-dokumen atau catatan-catatan disimpan dalam brankas, bahan baku disimpan dalam gudang. 
Selain kelima lambang standar tersebut, kita bisa menggunakan lambang lain apabila merasa perlu untuk mencatat suatu aktivitas yang memang terjadi selama proses berlangsung dan tidak terungkapkan oleh lambang-lambang tadi. Lambang tersebut ialah:

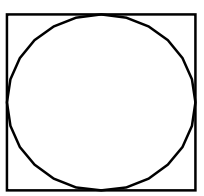

Aktivitas gabungan, Kegiatan ini terjadi apabila antara aktivitas operasi dan pemeriksaan dilakukan bersamaan pada suatu tempat kerja.

\subsection{Macam - Macam Peta Kerja}

Menurut Maryana(2015), pada dasarnya peta-peta bisa dibagi kedalam dua kelompok besar berdasarkan kegiatannya yaitu :

1. Peta-peta kerja yang digunakan untuk menganalisis kegiatan kerja keseluruhan.

2. Peta-peta kerja yang digunakan untuk menganalisis kegiatan kerja setempat.

Hubungan antara kedua macam kegiatan diatas akan terlihat bila untuk menyelesaikan suatu produk diperlukan beberapa stasiun kerja, dimana satu sama lainnya saling berhubungan, misalnya suatu perusahaan perakitan memiliki beberapa mesin produksi atau stasiun kerja. Dalam hal ini kelancaran proses produksi secara keseluruhan akan sangat tergantung pada kelancaran setiap sistem kerja. Sesuatu yang bijaksana apabila dalam prakteknya nanti, pelaksana pertama- 
tama berusaha untuk memperbaiki atau menyempurnakan setiap sistem kerja yang ada sedemikian rupa sehingga didapatkan suatu urutan kerja yang paling baik untuk saat itu. Barulah kemudian menyempurnakan proses secara keseluruhan.

\subsubsection{Peta Kerja Keseluruhan}

Suatu kegiatan disebut kegiatan kerja keseluruhan apabila kegiatan tersebut melibatkan sebagian besar atau semua fasilitas yang diperlukan untuk membuat produk yang bersangkutan(Arif,2016).

Menurut Erliana (2015), peta - peta yang termasuk kedalam peta kerja keseluruhan adalah:

\subsubsection{Peta proses operasi}

Peta proses operasi merupakan suatu diagram yang menggambarkan langkah-langkah proses yang akan dialami bahan baku mengenai urut-urutan operasi dan pemeriksaan, sejak dari awal sampai menjadi produk jadi secara utuh. Peta Proses Operasi biasa juga disebut dengan Peta OPC (Operation Process Chart)

\section{Kegunaan Peta Proses Operasi:}

- Bisa mengetahui kebutuhan akan mesin dan penganggarannya.

- Bisa memperkirakan kebutuhan akan bahan baku (dengan memperhatikan efisiensi ditiap operasi/pemeriksaan).

- Sebagai alat untuk menentukan tata letak pabrik. 
- $\quad$ Sebagai alat untuk melakukan perbaikan cara kerja yang sedang dipakai.

- Sebagai alat untuk latihan kerja.

\section{Prinsip Pembuatan:}

- Pada baris paling atas dinyatakan kepalanya "Peta Proses Operasi" yang diikuti oleh identifikasi lain seperti : nama obyek, nama pembuat peta, tanggal dibuat, nomor peta dan nomor gambar.

- Material yang akan diproses diletakan pd garis horisontal, yang menunjukkan bahwa material tersebut masuk kedalam proses.

- Lambang-lambang ditemaptkan dalam arah vertikal, yang menunjukkan terjadinya perubahan proses.

- Penomoran terhadap suatu suatu kegiatan operasi diberikan secara berurutan sesuai dengan urutan operasi yang dibutuhkan untuk pembuatan produk tersebut atau sesuai dengan proses yang terjadi.

- Penomoran terhadap suatu kegiatan pemeriksaan diberikan secara tersendiri dan pronsipnya sama dengan operasi.

Produk yang paling banyak memerlukan proses operasi dipetakkan terlebih dahulu disebelah paling kanan.(biasanya produk/komponen pokok). 


\section{Analisa Peta Proses Operasi:}

(a) Bahan-bahan

Mempertimbangkan semua alternatif dari bahan yang digunakan, proses penyelesaian dan toleransi sehingga sesuai dengan fungsi, reliabilitas, pelayanan dan waktunya.

(b) Operasi

Perbaikan yang mungkin dilakukan adalah dengan menghilangkan, menggabungkan, merubah atau menyederhanakan operasi yang terjadi.

(c) Pemeriksaan

Suatu obyek dikatakan memenuhi standar kualitasnya jika setelah dibandingkan dengan standar.

(d) Waktu 


\begin{tabular}{ll}
\hline NAMA PRODUK & $:$ DONUTS (1 TraY $=14$ pCS $)$ \\
NOMOR PETA & $: 1$ \\
DIPETAKAN OLEH & $:$ KELONPOK 1 \\
TANGGAL & $: 10$ OKTOOER 2016 \\
STUDI KASUS & $:$ J.CO DONUTS \& COFFEE \\
\hline
\end{tabular}

Pembuatan Topping

Dounes (1)

(collat, strauberry. vamilla, meses)

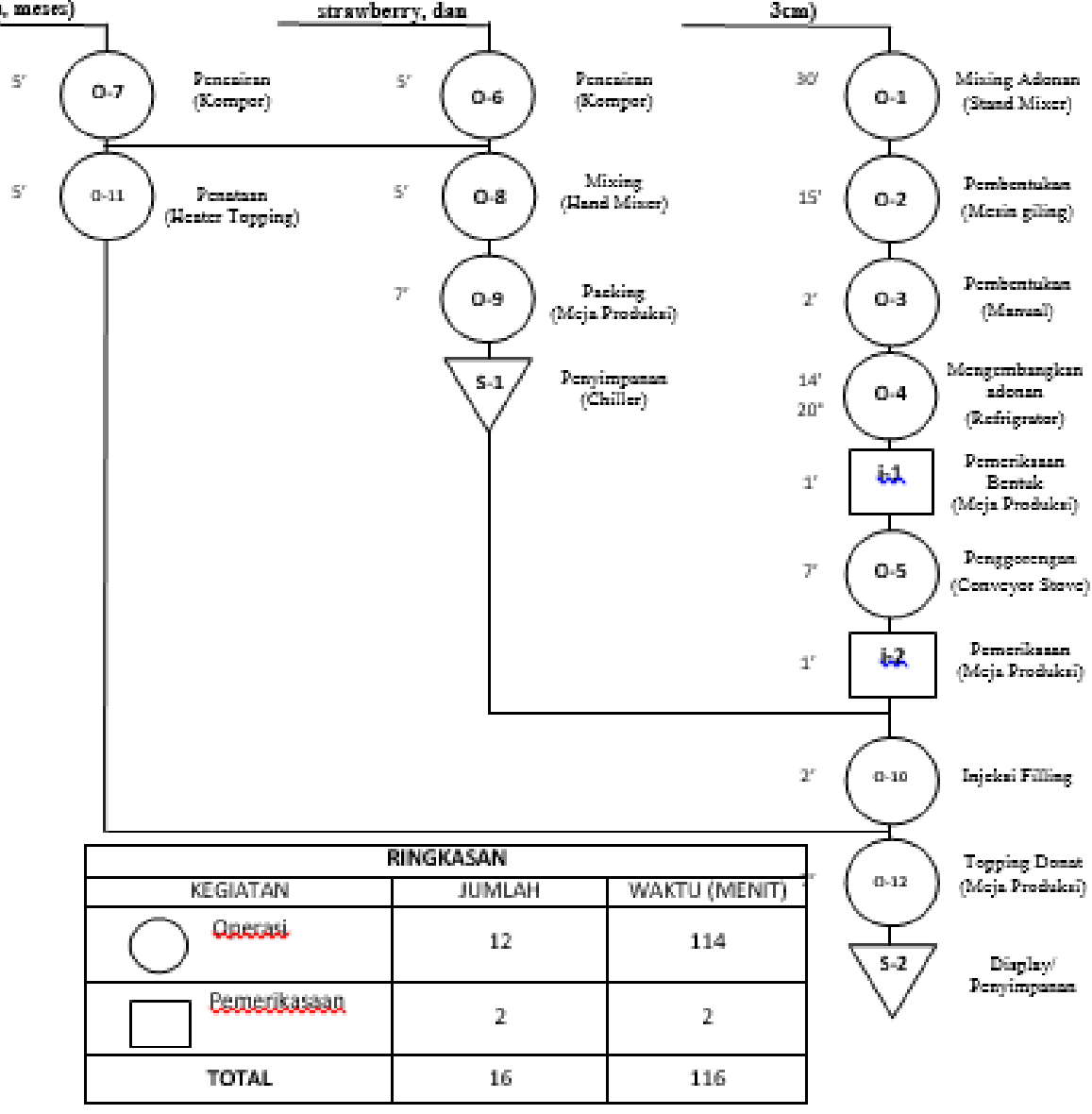

Gambar 2.1. Peta Proses Operasi 


\subsubsection{Peta Aliran Proses}

Peta Aliran Proses adalah suatu diagram yang menunjukkan uruturutan dari operasi, pemeriksaan, transportasi, menunggu dan peyimpanan yang terjadi selama satu proses atau prosedur berlangsung.

\section{Perbedaan PAP dan PPO:}

(a) PAP memperlihatkan semua aktivitas-aktivitas dasar, termasuk trasnportasi, menunggu, dan menyimpan. Sedang PPO terbatas pada Operasi dan Inspeksi saja.

(b) PAP menganalisa setiap komponen yang diproses secara lebih lengkap.

\section{Kegunaan :}

1. Digunakan untuk mengetahui aliran bahan atau aktivitas orang mulai awal masuk dalam sutau proses atau prosedur sampai aktivitas terakhir.

2. Memebrikan informasi mengenai waktu penyelesaian suatu proses.

3. Digunakan untuk mengetahui jumlah kegiatan yang dualami bahan atau dilakukan oleh orang selama proses berlangsung.

4. Seabagai alat untuk melakukan perbaikan proses kerja. 


\section{Prinsip Pembuatan:}

- Pada bagian paling atas ditulis PAP yang diikuti oleh keterangan lainnya (no gbr, pembuat, tanggal pembuatan, dll) yang terletak diatas bagian kanan.

- $\quad$ Di bagian kiri atas, dicatat mengenai ringkasan yang memuat jumlah total dan waktu total dari setiap kegiatan yang terjadi dan juga mengenai total jarak perpindahan yg dialami bahan atau org selama proses berlangsung.

- Pada bagian "badan" diuraikan proses yang terajadi secara lengkap beserta lambang-lambang dan informasi mengenai jarak perpindahan, jumlah yg dilayani, wkt yg dibutuhkan dan kecepatan produksi.

- Dianalisa dengan menggunakan " Dot and Check Tehnique".

Tabel 2.1. Dot and Check Tehnique

\begin{tabular}{|c|l|l|l|}
\hline NO & \multicolumn{1}{|c|}{ PERTANYAAN } & BERIKUTNYA & $\begin{array}{c}\text { TINDAKAN } \\
\text { YG } \\
\text { MUNGKIN } \\
\text { DILAKUKAN }\end{array}$ \\
\hline 1 & Apa tujuannya ? & Mengapa? & \\
2 & Dimana dikerjakan? & Mengapa? & \\
3 & Kapan dikerjakan? & Mengapa? & \\
4 & Siapa yang & Mengapa? & \\
5 & $\begin{array}{l}\text { Mengerjakan ? } \\
\text { Bagaiamana } \\
\text { mengerjakannya? }\end{array}$ & Mengapa? & \\
\hline
\end{tabular}




\section{Analisa :}

Melalui Dot and Check Tehnique yg didasarkan pada 6 pertanyaan diatas dengan perbaikan sbb:

(a) Menghilangkan aktivitas yg tidak perlu.

(b) Menggabungkan atau meribah tempat kerja.

(c) Menggabungkan atau merubah waktu atau urutan kerja.

(d) Menggabungkan atau merubah org.

(e) Menyederhanakan atau memperbaiki metode kerja.

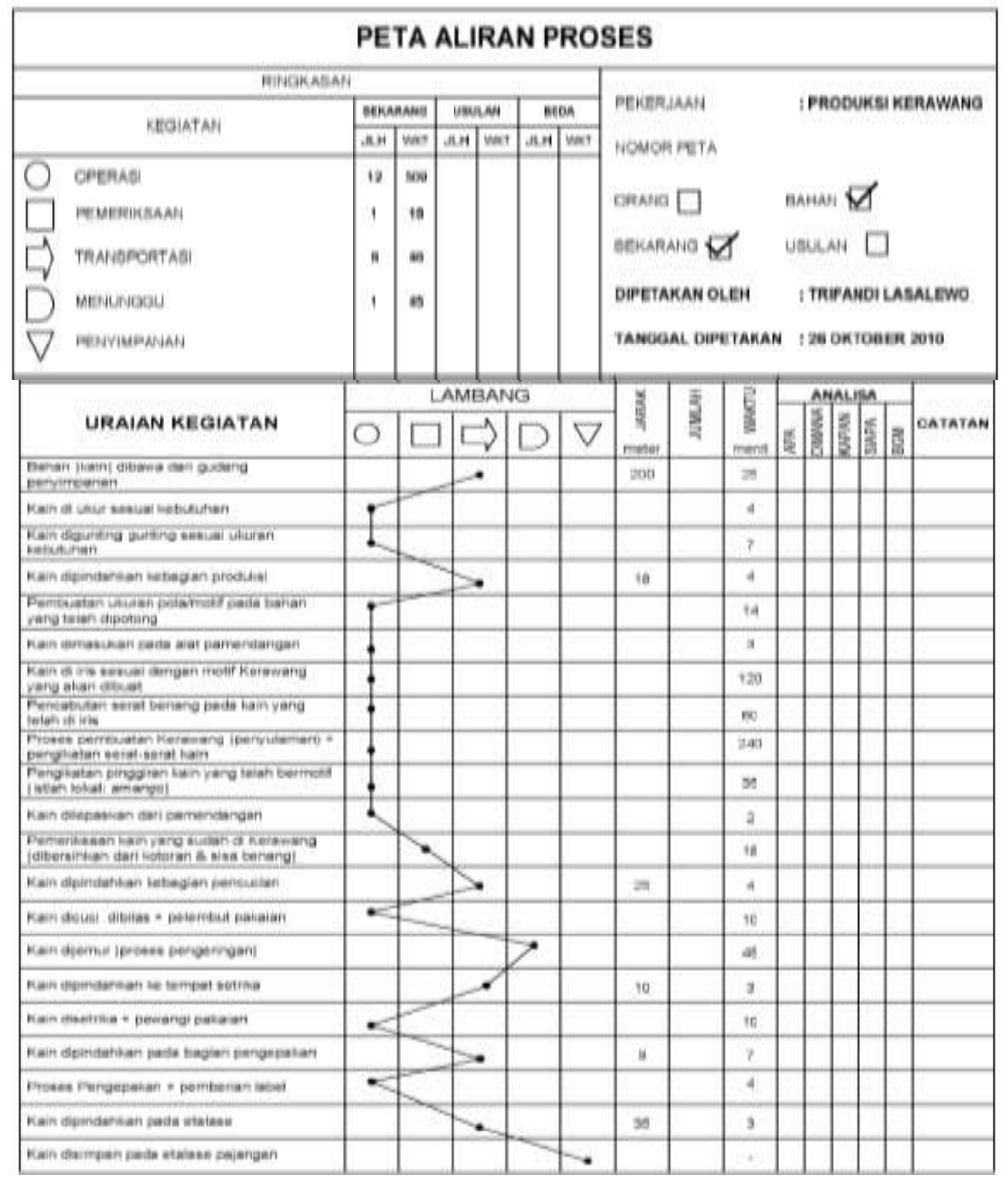

Gambar 2.2. Peta Aliran Proses 


\subsubsection{Diagram Aliran Proses}

Diagram Aliran Proses adalah suatu gambaran menurut skala dari susunan lantai dan gedung, yang menunjukkan lokasi dari semua aktivitas yang terjadi. Aktivitas yang berarti pergerakkan suatu material atau orang dari suatu tempat ketempat berikutnya dinyatakan oleh garis aliran dan arah aliran digambarkan oleh anak panah kecil pada garis aliran tersebut.

\section{Kegunaan:}

- $\quad$ Lebih memperjelas suatu PAP, apalagi jika arah aliran merupakan faktor yang penting.

- Membantu dalam perbaikan tata letak (layout) perusahaan.

\section{Prinsip Pembuatan:}

- Kepala gambar (peta).

- Identifikasikan setiap aktivitas dengan lambang dan nomor yang sesuai dengan yang digunakan dalam PAP.

- Arah gerakkan dinyatakan oleh anak panah kecil yang dibuat secara periodik sepanjang garis aliran.

- Apabila dalam ruangan tersebut terjadi lintasan lebih dari satu orang atau brg, maka tiap lintasan dibedakan dengan warna bermacam-macam. 


\section{Hal-hal yang diperhatikan dalam Diagram Aliran Proses:}

- Gerakan yang terlalu panjang/jauh untuk pemindahan dari satu operasi ke operasi berikutnya.

- Adanya dua atau lebih gerakan perpindahan di antara operasi kerja.

- $\quad$ Adanya dua atau lebih aktivitas inspeksi diantara operasi kerja.

- Adanya perubahan - perubahan arah aliran proses.

- Adanya gerakkan bolak-balik (backtracking).

- Adanya item volume besar yang harus dipindahkan dalam jarak yang jauh, sdgkan item volume kecil justru dipidahkan dlm jarak yg dekat.

- Lokasi gudang penyimpanan bahan baku atau produk jadi yg relatif berjauhan dgn area produksi. 
Diagram Aliran Proses

\begin{tabular}{ll}
\hline PEKERJAAN & $:$ Alir proses pembuatan donuts hingga ke \\
tangan konsumen & \\
NOMOR PETA & $: 1$ \\
SEKARANG & $:$ Usulan \\
DIPETAKAN OLEH & $:$ Kelompok 1 \\
TANGGAL & $: 10$ Oktober 2016
\end{tabular}

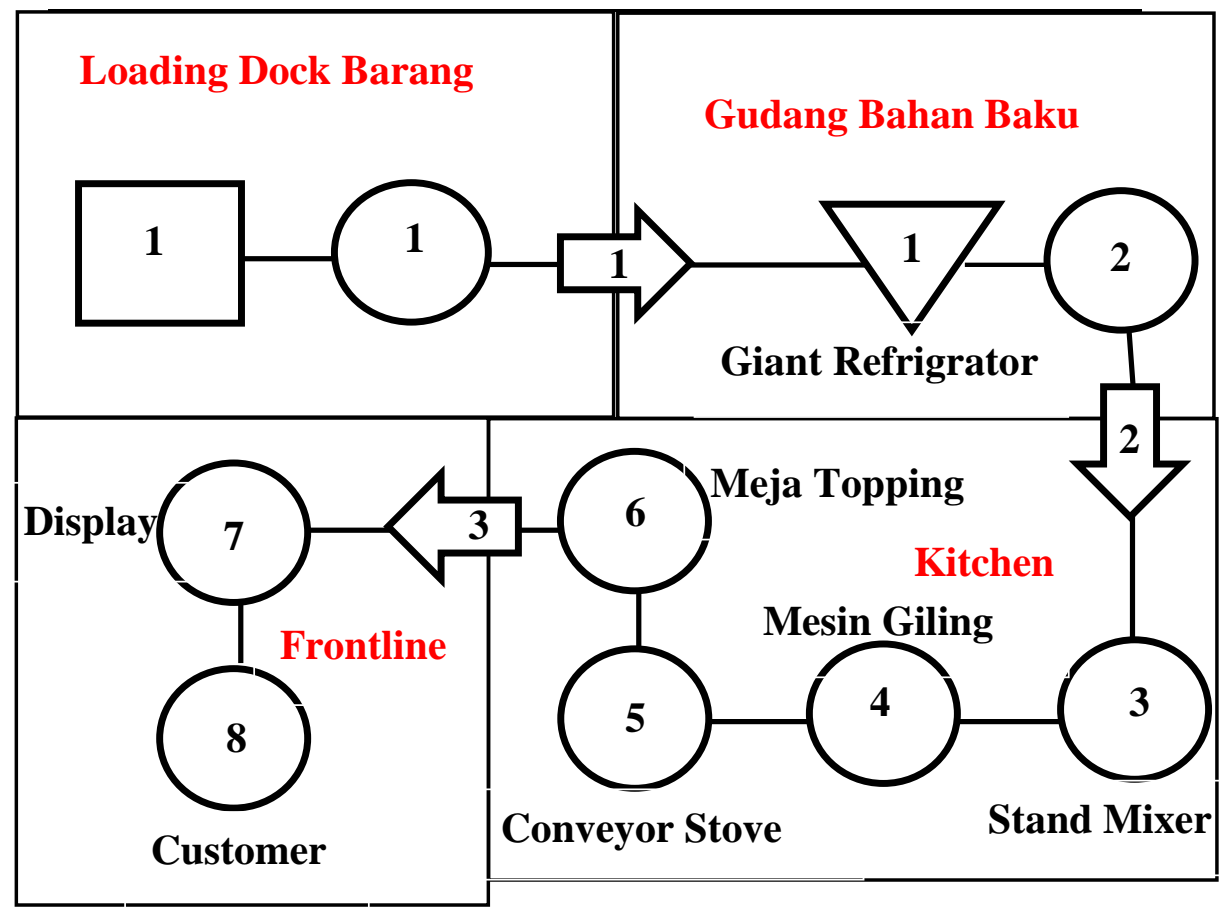

Gambar 2.3. Diagram Aliran Proses 


\subsubsection{Peta Proses Kelompok Kerja}

Peta Proses Kelompok Kerja adalah suatu diagram yang menjelaskan prosentase aktivitas kerja dalam satu kelompok/ regu kerja. Peta kerja ini akan memberikan gambaran mana pekerja yang produktif dan kurang produktif.

\section{Kegunaan:}

- Memberikan informasi aktivitas yang dilakukan oleh pekerja

- Memberikan informasi prosentase kerja dalam satu kelompok/ regu.

\section{Prinsip Pembuatan:}

- Kepala gambar (peta).

- Identifikasikan setiap aktivitas dengan lambang, waktu dan jarak yang sesuai dengan PAP.

- Prosentase kerja masing-masing pekerja harus ditulis.

- Uraian lambing kegiatan harus sesuai dengan aktivitas pada PAP. 


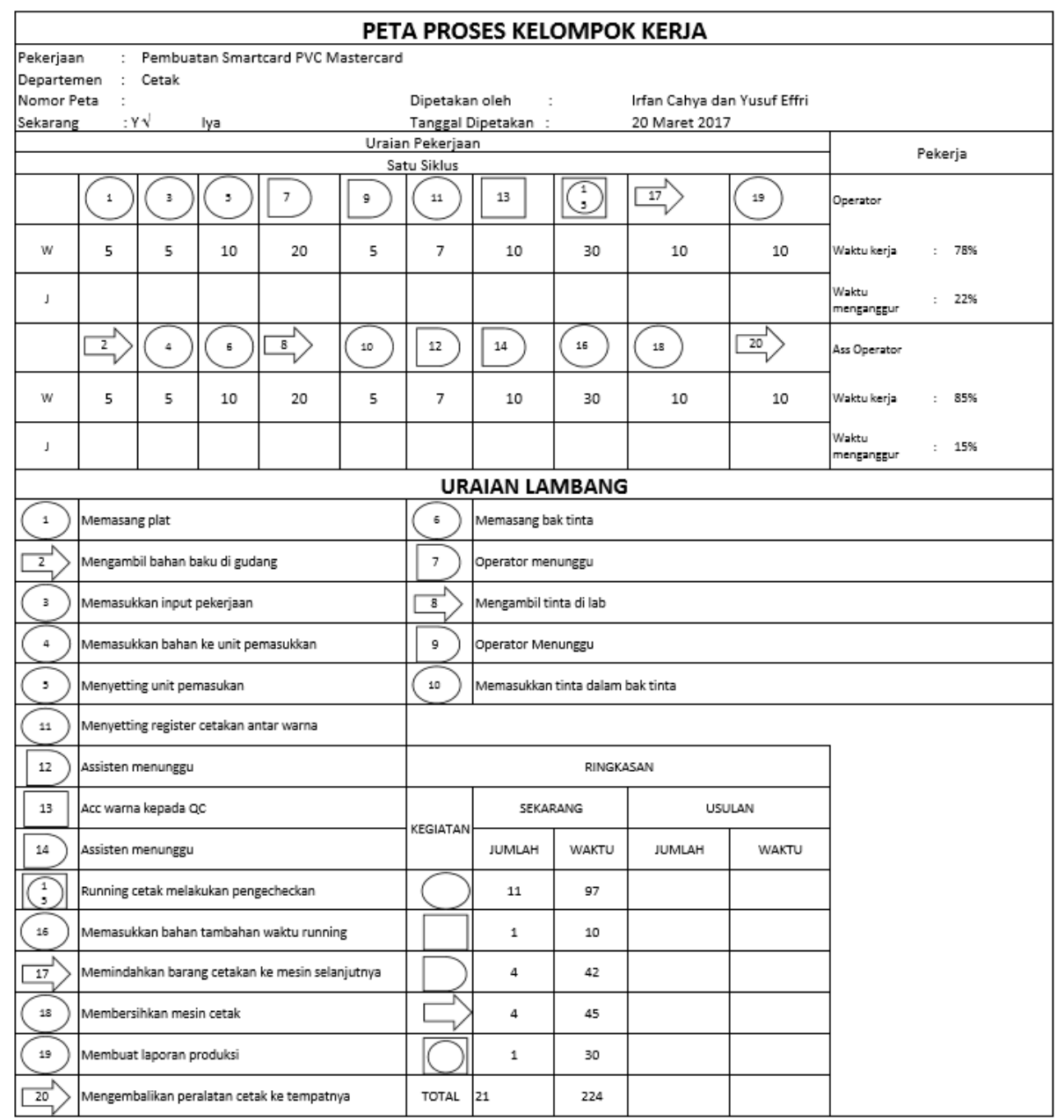

Gambar 2.4. Peta Proses Kelompok Kerja

\subsubsection{Peta Kerja Setempat}

Menurut Erliana (2015), suatu kegiatan disebut kegiatan kerja setempat apabila kegiatan tersebut terjadi dalam suatu stasiun kerja, 
biasanya hanya melibatkan orang dan fasilitas dalam jumlah terbatas. Peta - peta yang termasuk kedalam peta kerja kegiatan setempat adalah:

\subsubsection{Peta pekerja dan mesin}

Peta Pekerja dan mesin adalah suatu diagram yg menggambarkan koordinasi antara waktu bekerja dan waktu menganggur dari kombinasi antara pekerja dan mesin. Tujuan utamanya utk mengurangi waktu menganggur dari seorang operator.

\section{Kegunaan:}

- Merubah tata letak (layout).

- Layout merupakan salah satu faktor yg menentukan lamanya waktu penyelesaian suatu pekerjaan. Shg penataan kembali suatu layout diharapkan dpt menempatkan elemen sistem kerja yg dpt menghemat wkt penyelesaian.

- Mengatur kembali gerakan-gerakan kerja.

- Pada dasarnya gerakan kerja merupakan faktor yg menentukan wkt penyelesaian suatu pekerjaan.

- Merancang kembali mesin dan peralatan.

- Keadaan mesin dan peralatan sering kali perlu dirancang kembali utk meningkatkan efektivitas pekerja dn mesin, misal mengurangi wkt mengangkut dan sekaligus menghemat tenaga pekerja, maka pekerjaan memeindahkan brg 
terutama brg berat yg tadinya menggunakan gerobak dorong skrg perlu dipikirkan dgn menggunakan kereta (hoist).

- Menambah pekerja bagi sebuah mesin atau sebaliknya.

\section{Prinsip Pembuatan:}

- Kepala gambar (peta).

- Uraikan semua elemen pekerjaan yg terjadi.

- Lambang - lambang grs berskala yg digunakan:

- Garis penuh (solid line), menunjukan wkt kerja operator atau wkt operasi mesin.

- Garis putus-putus (dot line), menunjukan bhw mesin dlm keadaan loading $\&$ unloading yaitu kondisi dimana mesin idle atau tdk ada kerja produktif yg dilakukan saat itu.

- Tidak adanya garis dalam vertikal untuk kolom garis operator menunjukkan bahwa kondisi operator saat itu menganggur (idle), sedang kalau tdk adanya garis ini pada kolom mesin menunjukan bahwa mesin sedang menganggur tidak terbebani.

- Seluruh elemen-elemen kerja baik produktif maupun tidak produktif untuk manusia dan mesin dipetakkan secara penuh sampai satu siklus kerja berlangsung. 
PETA PEKERIA DAN MESIN

\begin{tabular}{|c|c|c|c|c|c|c|}
\hline PEKERJAAN & \multirow{3}{*}{\multicolumn{2}{|c|}{$\begin{array}{l}\text { : MIXING ADONAN DONUTS } \\
\text { : BAKER X } \\
\text { : KELOMPOK } 1\end{array}$}} & \multicolumn{4}{|c|}{ NAMA MESIN : STAND MIXER } \\
\hline NAMA PEKERJA & & & \multicolumn{4}{|c|}{ SEKARANG $\quad$ : USULAN } \\
\hline DIPETAKAN OLEH & & & \multicolumn{4}{|c|}{ TANGGAL $\quad: 10$ OKTOBER 2016} \\
\hline \multicolumn{3}{|c|}{ ORANG } & \multicolumn{4}{|c|}{ MESIN } \\
\hline OPERATOR & \multicolumn{2}{|c|}{ WAKTU (DETIK) } & \multicolumn{2}{|c|}{ STAND MIXER } & \multicolumn{2}{|c|}{ WAKTU (DETIK) } \\
\hline $\begin{array}{l}\text { Pembuatan adonan ke dalam } \\
\text { loyang mixer }\end{array}$ & 600 & & \multicolumn{2}{|c|}{ Mesin dalam keadaan off } & 600 & 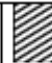 \\
\hline $\begin{array}{l}\text { Mencairkan coklat bahan } \\
\text { fillingan }\end{array}$ & 300 & & \multicolumn{2}{|c|}{ Mesin dalam keadaan on } & 300 & \\
\hline $\begin{array}{l}\text { Mencampurkan coklat bahan } \\
\text { fillingan dengan white cream }\end{array}$ & 120 & & \multicolumn{2}{|c|}{ Mesin dalam keadaan on } & 120 & \\
\hline $\begin{array}{l}\text { Mencairkan coklat bahan } \\
\text { toppingan }\end{array}$ & 300 & & \multicolumn{2}{|c|}{ Mesin dalam keadaan on } & 300 & \\
\hline $\begin{array}{l}\text { Menyiapkan coklat toppingan } \\
\text { ke dalam meja topping }\end{array}$ & 120 & & \multicolumn{2}{|c|}{ Mesin dalam keadaan on } & 120 & \\
\hline $\begin{array}{l}\text { Merapikan dan membersihkan } \\
\text { meja kitchen serta topping }\end{array}$ & 180 & & \multicolumn{2}{|c|}{ Mesin dalam keadaan on } & 180 & \\
\hline $\begin{array}{l}\text { Menunggu proses mixing } \\
\text { adonan donuts selesai }\end{array}$ & 80 & "/l/ & \multicolumn{2}{|c|}{ Mesin dalam keadaan on } & 80 & \\
\hline $\begin{array}{l}\text { Menuangkan adonan fillingan } \\
\text { ke dalam mixer }\end{array}$ & 10 & & \multicolumn{2}{|c|}{ Mesin dalam keadaan off } & 10 & 济 \\
\hline $\begin{array}{l}\text { Menunggu proses mixing } \\
\text { adonan filling selesai }\end{array}$ & 300 & "l//" & \multicolumn{2}{|c|}{ Mesin dalam keadaan on } & 300 & \\
\hline OBYEK & \multicolumn{3}{|c|}{ OPERATOR } & \multicolumn{3}{|c|}{ MESIN } \\
\hline WAKTU MENUNGGU & \multicolumn{3}{|l|}{380} & \multicolumn{3}{|l|}{610} \\
\hline WAKTU KERJA & \multicolumn{3}{|l|}{1630} & 1400 & & \\
\hline TOTAL WAKTU & 2010 & & & 2010 & & \\
\hline PROSENTASE PENGGUNAAN & $81,1 \%$ & & & $70,15 \%$ & & \\
\hline
\end{tabular}

Gambar 2.5. Peta Pekerja dan Mesin

2.3.2.2. Peta tangan kiri dan tangan kanan

Peta Tangan Kiri dan Tangan Kaknan adalah suatu diagram yg menggambarkan aktivitas gerakan tangan dari seorang operator, mengingat keseimbangan penggunaan kedua tangan sangat berpengaruh terhadap produktivitas kerja seorang pekerja. 


\section{Kegunaan:}

- Mengetahui keseimbangan penggunaan kedua tangan.

- Mengetahui lamanya waktu aktivitas dari tangan.

- Mengetahui jumlah total lamanya aktivitas dari sebuah pekerjaan.

- Mengetahui aktivitas apa saja yang dilakukan.

- Mmperbaiki aktivitas kerja yang tidak perlu.

\section{Prinsip Pembuatan:}

- Kepala gambar (peta).

- Uraikan semua elemen pekerjaan yang dialami oleh kedua tangan.

- Lambang - lambang aktivitas menurut symbol Therbligh yang digunakan: 
PETA TANGAN KIRI DAN TANGAN KANAN

\begin{tabular}{llll}
\hline PEKERJAAN & $:$ Pembuatan Adonan Donat & DEPARTEMEN & $:-$ \\
NOMOR PETA & $: 1$ & SEKARANG & $:$ USULAN \\
DIPETAKAN OLEH & $:$ Kelompok 1 & TANGGAL & $: 10$ Oktober 2016
\end{tabular}

\begin{tabular}{|l|l|l|l|l|l|l|}
\hline \multicolumn{1}{|c|}{ Tangan Kiri } & $\begin{array}{c}\text { Jarak } \\
\text { (cm) }\end{array}$ & $\begin{array}{l}\text { Waktu } \\
\text { (det) }\end{array}$ & Lambang & $\begin{array}{c}\text { Waktu } \\
\text { (det) }\end{array}$ & $\begin{array}{c}\text { Jarak } \\
(\mathbf{c m})\end{array}$ & \multicolumn{1}{|c|}{ Tangan Kanan } \\
\hline Menunggu & 0 & 2 & & 2 & 100 & Mengambil Tepung \\
\hline Memegang kemasan tepung & 0 & 1 & & 1 & 0 & Membuka kemasan tepung \\
\hline Memegang kemasan tepung & 0 & 2 & & 2 & 10 & Menuangkan ke dalam mixer \\
\hline Mengambil air & 100 & 5 & & 1 & 100 & Membuka kran air mineral \\
\hline Menunggu & 0 & 1 & & 1 & 100 & Menuangkan ke dalam mixer \\
\hline Mengambil bahan adonan lain & 50 & 2 & & 2 & 50 & Menunggu \\
\hline Memegang kemasan bahan & 0 & 2 & & 2 & 0 & Membuka kemasan bahan \\
\hline Menekan tombol mixer & 10 & 1 & & 3 & 10 & Menuangkan ke dalam mixer \\
\hline $\begin{array}{l}\text { Mengambil coklat bahan fillingan } \\
\text { dan toppingdonat }\end{array}$ & 50 & 3 & & 3 & 50 & Menunggu \\
\hline Menuangkan ke dalam panci & 40 & 2 & & 1 & 40 & Menyalakan kompor \\
\hline Menunggu & 0 & 10 & & 10 & 0 & $\begin{array}{l}\text { Mengaduk coklat yang } \\
\text { dipanaskan }\end{array}$ \\
\hline $\begin{array}{l}\text { Mengambil cairan campuran } \\
\text { bahanfilling donat }\end{array}$ & 40 & 3 & & 3 & 40 & menunggu \\
\hline Memegang kemasan & 40 & 2 & & 2 & 40 & Membuka kemasan \\
\hline Membawa tray ke dalam rak & 100 & 2 & & 2 & 100 & Membawa tray ke dalam rak \\
\hline TOTAL & & & & & & \\
\hline
\end{tabular}

Gambar 2.6. Peta Tangan Kiri dan Tangan Kanan 


\section{Contoh Soal}

1. Sebuah produk Antena TV PF 100 memiliki komponen pokok meliputi:

- Pipa Kubus ukuran 1,5 x 1,5 cm (komponen utama)

- Pipa Kubus ukuran 1,1 x 1,1 cm (komponen ke II)

- Pipa Kubus ukuran diameter 3/8 inch. (komponen ke III)

- Komponen Pelengkap

Proses yang terjadi untuk masing-masing komponen:

$\Phi \quad$ Pipa Kubus ukuran 1,5 x 1,5 cm

- Diukur dengan meteran

- Dipotong dengan tubbing cutter

- Dikikir dan diinspeksi kehalusannya

- Diukur

- Dilubangi dengan mesin drilling

- $\quad$ Dikikir dan diinspeksi

$\Phi \quad$ Pipa Kubus ukuran 1,1 x 1,1 cm

- Analog dengan komponen diatas

$\Phi \quad$ Pipa Kubus ukuran diameter 3/8 inch.

- Diukur dengan meteran

- Dipotong

- Dikikir dan diperiksa

$\Phi \quad$ Komponen Pelengkap

- Langsung masuk pada perakitan 


\section{Catatan:}

Urutan komponen seperti urutan komponen di atas.

Waktu untuk setiap operasi:

\begin{tabular}{|l|c|}
\hline \multicolumn{1}{|c|}{ Operasi } & Waktu \\
\hline - Pengukuran & 0,5 menit \\
- Pemotongan dan & 1 menit \\
- Pengikiran & 5 menit \\
inspeksi & 2 menit \\
- Pelubangan & 15 menit \\
- Perakitan & \\
\hline
\end{tabular}

a. Buatlah PPO nya lengkap

b. Sebutkan simbol-simbol ASME dalam TTC!

c. Sebutkan dan tuliskan simbol THERBLIGH

2. Diketahui interaksi pekerjaan antara Manusia dan Mesin sebagai berikut:

\begin{tabular}{|c|c|c|c|}
\hline Operator & $\begin{array}{l}\text { Waktu } \\
\text { (dalam } \\
\text { detik) }\end{array}$ & Mesin Bubut & $\begin{array}{c}\text { Waktu } \\
\text { (dalam detik) }\end{array}$ \\
\hline $\begin{array}{l}\text { Berbicara dan konsultasi } \\
\text { dengan Kepala produksi }\end{array}$ & 900 & $\begin{array}{l}\text { Dalam keadaan } \\
\text { mesin off }\end{array}$ & .......... \\
\hline $\begin{array}{l}\text { Mengecek dan memriksa } \\
\text { komponen yang akan dibuat }\end{array}$ & 600 & $\begin{array}{ll}\text { Dalam keadaan } \\
\text { dipanasi }\end{array}$ & ........... \\
\hline $\begin{array}{l}\text { Menaruh benda kerja } \\
\text { (komponen) ke kepala bubut }\end{array}$ & 120 & $\begin{array}{l}\text { Dalam keadaan } \\
\text { siap }\end{array}$ & .......... \\
\hline Menghidupkan mesin & 45 & Ready & ........... \\
\hline $\begin{array}{l}\text { Menunggu mesin sedang } \\
\text { membubut benda kerja }\end{array}$ & ........... & $\begin{array}{l}\text { Mengerjakan bubut } \\
\text { dalam keadaan } \\
\text { otomatis }\end{array}$ & 720 \\
\hline $\begin{array}{l}\text { Memeriksa hasil bubut dan } \\
\text { ukurannya }\end{array}$ & 60 & $\begin{array}{l}\text { Berhenti } \quad \mathrm{dlm} \\
\text { keadaan ready }\end{array}$ & ........ \\
\hline Menaruh benda kerja ke-2 & 90 & Ready & $\ldots \ldots \ldots$ \\
\hline
\end{tabular}




\begin{tabular}{|l|c|l|c|}
\hline Menunggu & $\ldots \ldots .$. & $\begin{array}{l}\text { Mesin sedang } \\
\text { memboring }\end{array}$ & 120 \\
\hline $\begin{array}{l}\text { Memeriksa hasil } \\
\begin{array}{l}\text { produksi untuk } \\
\text { mengkonsultasikan hasil } \\
\text { spesifikasi komponen. }\end{array}\end{array}$ & 60 & Ready & $\ldots \ldots .$. \\
\hline
\end{tabular}

a. Buatlah Peta Pekerja dan mesinnya! 


\section{BAB. 3}

\section{PENGUKURAN WAKTU KERJA}

\subsection{Pengukuran Waktu Kerja}

Pengukuran waktu kerja dan analisis metode kerja pada dasarnya memusatkan pada bagaimana pekerjaan tersebut diselesaikan. Pengukuran waktu kerja adalah pekerjaan mengamati perkerja dan mencatat waktu kerjanya baik tiap elemen maupun siklus. Tujuan dari pengukuran waktu kerja adalah untuk menentukan waktu kerja rata-rata yang dibutuhkan oleh operator dalam melakukan suatu pekerjaan. Tujuannya untuk mendapatkan waktu baku atau yang biasa dikenal diperusahaan dengan sebutan Cycle Time, yakni waktu yang secara wajar untuk menyelesaikan suatu pekerjaan yang dilaksanakan dalam system kerja terbaik yang sudah mempertimbangkan unsur kelonggaran (allowance) yang diperlukan oleh seorang pekerja. Pengukuran waktu kerja dapat dilakukan secara langsung, yaitu suatu bentuk atau cara pengukuran kerja yang dilakukan di tempat dimana pekerjaan tersebut dijalankan(Darsini, 2014). Adapun alur urutan kerja yang dilakukan pada pengukuran waktu kerja ini dapat dilihat pada Gambar 3.1 di bawah ini: 


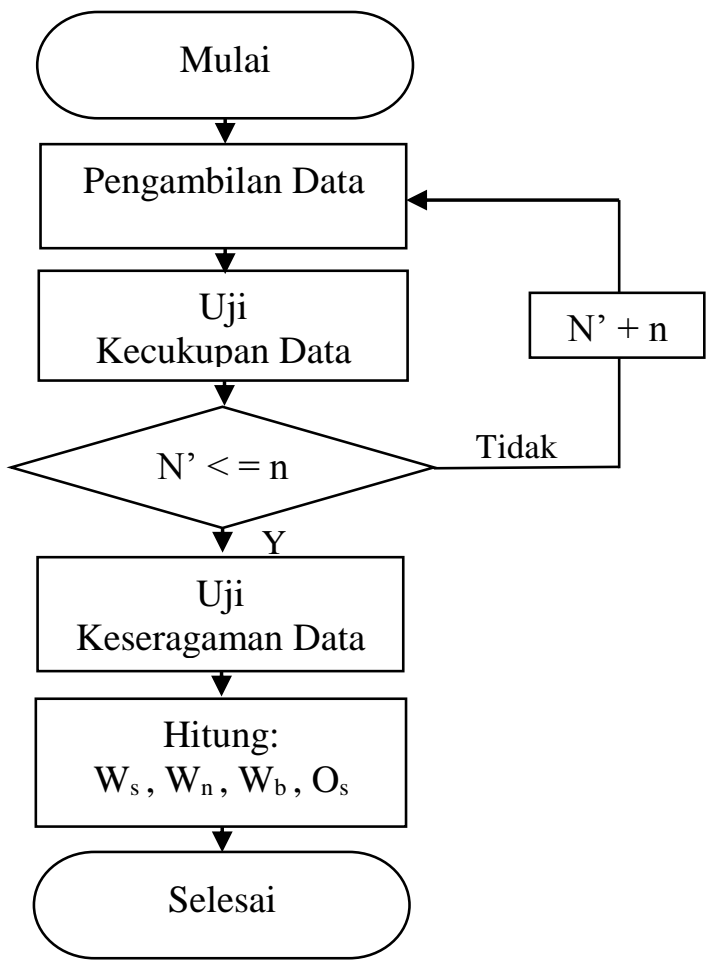

Gambar 3.1. Alur (Flowchart) Pengukuran Waktu Kerja

\subsection{Uji Kecukupan Data}

Menurut Darsini (2014), untuk menetapkan berapa jumlah pengamatan yang seharusnya dilakukan di sini diputuskan dahulu tingkat keyakinan (confidence of accurancy) untuk mengukuran ini yang merupakan tingkat kepastian yang diinginkan oleh pengamat / analis berkenaan dengan pengamatan yang dilakukan tersebut. Di dalam aktifitas pengukuran kerja biasanya diambil 95\% tingkat keyakinan, dan 5\% derajat ketelitian. Hal ini berarti bahwa sekurangkurangnya 95 dari 100 rata-rata dari waktu dicatat / diukur untuk 
suatu elemen kerja akan memiliki penyimpangan lebih dari $5 \%$ dengan demikian formula yang digunakan sebagai berikut:

$$
N^{\prime}=\left[\frac{k / s \cdot \sqrt{n \cdot \Sigma \mathrm{x}^{2}-\left(\sum x\right)^{2}}}{\sum x}\right]^{2}
$$

Sumber: Darsini, 2014

Keterangan:

$N^{\prime}=$ Kecukupan data

$\mathrm{N}=$ Banyak data yang diukur

$\mathrm{K}=$ Tingkat kepercayaan

$\mathrm{S}=$ Derajat ketelitian

\subsection{Uji Keseragaman Data}

Data yang diperoleh dari pengukuran terlebih dahulu dilakukan uji keseragaman data sebelum digunakan untuk menetapkan waktu baku. Uji keseragaman data dilaksanakan dengan mengaplikasikan peta control (control chart) adalah suatu alat yang cocok untuk menguji keseragaman data yang diperoleh dari pengamatan.

Data yang diperoleh dari pengukuran dikelompokkan ke dalam sub group (Darsini, 2014).

$$
\begin{aligned}
& \mathrm{BKA}=x+k . \sigma \\
& \mathrm{BKB}=x-k . \sigma
\end{aligned}
$$

Sumber: Darsini, 2014 
Keterangan:

$\mathrm{X}=$ Rata-rata waktun pengamatan

$\mathrm{K}=$ Konstanta tingkat kepercayaan (convidence level)

Tingkat kepercayaan $68 \%, \mathrm{k}=1$

Tingkat kepercayaan $95 \%, k=2$

Tingkat kepercayaan $99 \%, \mathrm{k}=3$

$\sigma=$ Standar deviasi

Sedangkan standar deviasi dihitung dengan menggunakan rumus:

$$
\sigma=\sqrt{\frac{\sum(x i-\bar{x})^{2}}{(n-1)}}
$$

Sumber: Darsini, 2014

Keterangan:

$\mathrm{n}=$ Jumlah pengukuran

$\mathrm{X}_{\mathrm{i}}=$ Hasil pengukuran

$\bar{x}=$ Rata-rata hasil pengukuran

\subsection{Performance Rating}

MenurutCahyawati(2018), performance rating adalah komparasi dari performansi aktual operator dengan konsep yang sudah terdefinisikan dalam keadaan performansi normal. 
Performance rating adalah proses dimana analisa pengukuran waktu membandingkan penampilan operator (kecepatan atau tempo) dalam pengamatan dengan konsep pengukur sendiri tentang bekerja secara wajar. Waktu baku yang telah kita cari adalah waktu yang diperoleh dari kondisi dan cara kerja yang diselesaikan secara wajar dan benar oleh operator. Bila ketidakwajaran terjadi, maka pengukur harus menilainya dan berdasarkan penilaian inilah penyesaian dilakukan.

Adapun cara perhitungan performansi operator ini memiliki dua metode atau cara perhitungan yang biasa digunakan, yaitu Westing House dan Schumard.

\subsubsection{Westing House System's Rating}

Menurut Cahyawati (2018), metode yang digunakan untuk mengukur performansi kerja seseorang dengan acuan empat kriteria yaitu kecakapan, usaha, kondisi kerja, dan konsistensi dari operator di dalam melakukan pekerjaan.

Tabel 3.1 Westing House System's Rating

\begin{tabular}{|c|c|c|c|}
\hline Faktor & Kelas & Lambang & Penyesuaian \\
\hline & Superskill & A1 & $+0,15$ \\
& & A2 & $+0,13$ \\
& Excellent & B1 & $+0,11$ \\
Keterampilan & & B2 & $+0,08$ \\
(Skill) & Good & C1 & $+0,06$ \\
& & C2 & $+0,03$ \\
& Average & D & 0,00 \\
& Fair & E1 & $-0,05$ \\
\hline
\end{tabular}




\begin{tabular}{|c|c|c|c|}
\hline & Poor & $\begin{array}{l}\text { E2 } \\
\text { F1 } \\
\text { F2 }\end{array}$ & $\begin{array}{r}-0,10 \\
-0,16 \\
-0,22\end{array}$ \\
\hline \multirow{11}{*}{$\begin{array}{l}\text { Usaha } \\
\text { (Effort) }\end{array}$} & \multirow[t]{2}{*}{ Excessive } & A1 & $+0,13$ \\
\hline & & $\mathrm{A} 2$ & $+0,12$ \\
\hline & \multirow[t]{2}{*}{ Excellent } & B1 & $+0,10$ \\
\hline & & B2 & $+0,08$ \\
\hline & Good & $\mathrm{C} 1$ & $+0,05$ \\
\hline & \multirow[t]{2}{*}{ Average } & $\mathrm{C} 2$ & $+0,02$ \\
\hline & & $\mathrm{D}$ & $+0,00$ \\
\hline & \multirow[t]{2}{*}{ Fair } & E1 & $-0,04$ \\
\hline & & E2 & $-0,08$ \\
\hline & \multirow[t]{2}{*}{ Poor } & $\mathrm{F} 1$ & $-0,12$ \\
\hline & & $\mathrm{F} 2$ & $-0,17$ \\
\hline \multirow{6}{*}{ Kondisi Kerja } & Ideal & $A$ & $+0,06$ \\
\hline & Excellenly & B & $+0,04$ \\
\hline & Good & C & $+0,02$ \\
\hline & Average & $\mathrm{D}$ & 0,00 \\
\hline & Fair & $E$ & $-0,03$ \\
\hline & Poor & $\mathrm{F}$ & $-0,07$ \\
\hline \multirow{6}{*}{$\begin{array}{l}\text { Konsistensi } \\
\text { (Consistency) }\end{array}$} & Perfect & $A$ & $+0,04$ \\
\hline & Excellent & B & $+0,03$ \\
\hline & Good & $\mathrm{C}$ & $+0,01$ \\
\hline & Average & $\mathrm{D}$ & 0,00 \\
\hline & Fair & $E$ & $-0,02$ \\
\hline & Poor & $\mathrm{F}$ & $-0,04$ \\
\hline
\end{tabular}

\subsubsection{Schumard}

Cara schumard memberi patokan-patokan penilaian melalui kelas-kelas kinerja kerja dengan setiap kelas mempunyai nilai sendiri-sendiri. Disini patokan penilaian melalui kelas-kelas Good, Normal, Fair +, Fair, Fair - dan seterusnya. 
Patokan penilaian ini merupakan acuan penilaian yang ditentukan sendiri oleh perusahaan. Sebaiknya kategori dari masing-masing penilaian pada Metode Schumard ini diberikan deskripsi yang jelas, hal ini akan memberikan alasan yang obyektif terhadap penilaian yang diberikan pada seorang pekerja.

\begin{tabular}{|c|c|c|}
\hline Kelas & Penyesuaian & Deskripsi \\
\hline Superfast & 100 & \\
Fats + & 95 & \\
Fast & 90 & \\
Fast - & 85 & \\
Excellent & 80 & \\
Good+ & 75 & \\
Good & 70 & \\
Good- & 65 & \\
Normal & 60 & \\
Fair + & 55 & \\
Fair & 50 & \\
Fair - & 45 & \\
Poor & 40 & \\
\hline
\end{tabular}

Tabel 3.3. Performance Rating menurut Schumard

\subsection{Kelonggaran (Allowance)}

Menurut Cahyawati (2018), allowance adalah lama waktu yang terjadi saat sebuah jeda waktu yang terjadi dalam sebuah aktivitas rutin operasional.Suatu hal yang tidak mungkin bahwa seorang tidak mungkin bekerja seharian tanpa gangguan. Kelonggaran merupakan 
waktu yang dibutuhkan oleh pekerja yang terlatih agar dapat mencapai performansi kerja sesungguhnya jika ia bekeja secara normal. Bagaimanapun seseorang pekerja tidak mungkin dapat bekerja sepanjang hari tanpa adanya beberapa intrupsi untuk kebutuhan tertentu yang sifatnya manusiawi.

Kelonggaran yang dibutuhkan oleh seorang operator atau pekerja diklasifikasikan menjadi tiga kategori, yaitu :

1. Kelonggaran untuk kebutuhan pribadi berdasarkan penelitian ternyata besarnya kelonggaran ini bagi pria dan wanita berbeda. Bagi pria kelonggarannya $2 \%-2,5 \%$, sedangkan untuk wanita $2,5 \%-5 \%$.

2. Kelonggaran untuk menghilang-kan rasa fatique. Rasa fatique biasanya terlihat saat hasil produksi menurun,baik kuantitas maupun kualitas.

3. Kelonggaran untuk hambatan hambatan yang tak terhindarkan. Beberapa contoh dari hambatan yang tidak dapat dihinarkan adalah, menerima atau meminta petunjuk dari pengawas, melakukan penyesuaian mesin, memperbaiki kemacetan kemacetan singkat.

\subsection{Waktu Siklus}

Waktu siklus adalah data waktu yang diperoleh dari stopwatch yang kemudian dibagi dengan banyaknya pengamatan sehingga menjadi rata-rata. Rumus dari waktu 
siklus adalah sebagai berikut :

$$
\mathrm{W}_{\mathrm{s}}=\frac{\sum \mathrm{X}}{\mathrm{n}}
$$

Sumber : Wibisono, 2016

Keterangan rumus:

$\mathrm{Xi}=$ jumlah waktu

penyelesaian yang

teramati $\mathrm{n}=$ jumlah

pengamatan yang

dilakukan

\subsection{Waktu Normal}

Waktu normal adalah waktu penyelesaian pekerjaan yang diselesaikan oleh pekerja dengan mempertimbangkan faktor penyesuaian atau biasa disebut performance rating.Waktu normal bertujuan untuk mendapatkan waktu dengan kemampuan rata-rata dalam kondisi yang wajar. Rumus dari perhitungan waktu normal adalah sebagai berikut.

$$
\mathrm{Wn}=\mathrm{Ws} \times \mathrm{Pr}
$$

Sumber : Wibisono, 2016 
Keterangan Rumus:

Ws=Waktu Siklus

$\operatorname{Pr}=$ performancerating

Dimana performance rating adalah faktor penyesuaian. Faktor ini diperhitungkanbila operator bekerja dengan tidak wajar sehingga hasil perhitungan waktu perlu disesuaikan untuk mendapatkan waktu penyelesaian pekerjaan yangnormal.

\subsection{Waktu Baku}

Waktu baku adalah waktu yang dibutuhkan secara wajar oleh pekerja dengan kondisi normal untuk menyelesaikan pekerjaannya yang dikerjakan dalam sistem kerja terbaik. Waktu baku didapatkan dari hasil penghitungan sebagai berikut

$$
\mathrm{Wb}=\mathrm{Wnx} \quad \frac{100 \%}{100 \% \text {-allowance }(\%)}
$$

Sumber : Wibisono, 2016

Keterangan rumus:

Wn = waktu normal

Allowance $=$ tingkat kelonggaran 


\subsection{Output Standard}

Output standard adalah indikasi keluaran (output), berikut adalah rumus dari data outputstandard

$\mathrm{Os}=\frac{1}{\mathrm{~Wb}}$

Sumber : Wibisono, 2016

Soal

1. Diketahui pengukuran sebuah aktivitas sebagai berikut:

\begin{tabular}{|c|c|c|c|c|c|}
\hline \multirow{2}{*}{$\begin{array}{c}\text { Pengam } \\
\text { atan }\end{array}$} & \multicolumn{5}{|c|}{ Elemen - elemen Kegiatan } \\
\cline { 2 - 6 } & Elemen 1 & Elemen 2 & Elemen 3 & Elemen 4 & Elemen 5 \\
\hline 1 & 15 & 62 & 33 & 51 & 23 \\
\hline 2 & 14 & 58 & 21 & 50 & 26 \\
\hline 3 & 24 & 59 & 36 & 55 & 24 \\
\hline 4 & 13 & 61 & 38 & 48 & 38 \\
\hline 5 & 16 & 38 & 34 & 53 & 27 \\
\hline 6 & 17 & 62 & 35 & 54 & 25 \\
\hline 7 & 15 & 60 & 31 & 52 & 26 \\
\hline 8 & 18 & 66 & 40 & 56 & 26 \\
\hline 9 & 15 & 88 & 30 & 55 & 22 \\
\hline 10 & 18 & 65 & 32 & 60 & 26 \\
\hline
\end{tabular}


Pertanyaan!

- Hitunglah Tes Keseragaman Data.

- Dengan menggunakan $\mathrm{CL}$ sebesar 99 \% ( harga $\mathrm{k}=3$ ) dan $\mathrm{S}=5 \%$, lakukan test kecukupan data untuk tiap elemen.

- Jika diketahui Performance Rating sesuai dengan Westinghouse sbb:

Ketrampilan excellent (B2) $(+0,08)$

Usaha Good (C1) (+0,05)

Lingkungan Kerja---------- excellent (B) $(+0,04)$

Konsistensi------------------ poor (F) $(-0,04)$

Carilah $\mathrm{W}_{\mathrm{s}}, \mathrm{W}_{\mathrm{n}}, \mathrm{W}_{\mathrm{b}}, \mathrm{O}_{\mathrm{s}}$ 


\section{BAB. 4}

\section{SISTEM KERJA MANUSIA DAN MESIN}

\subsection{Sistem Hubungan Manusia-Mesin}

Manusia dalam bekerja dalam sistem kerja tidak bisa berjalan dengan sendirinya tanpa bantuan mesin dan peralatan sehingga manusia bergantung pada mesin dan peralatan tersebut dan juga lingkungan kerja.

Ada 3 macam hubungan kerja antar manusia dan mesin yaitu :

a. Sistem manusia mesin secara manual.

b. Sistem manusia mesin secara semi automatic

c. Sistem manusia mesin secara automatic.

\subsubsection{Sistem Manusia Mesin Secara Manual}

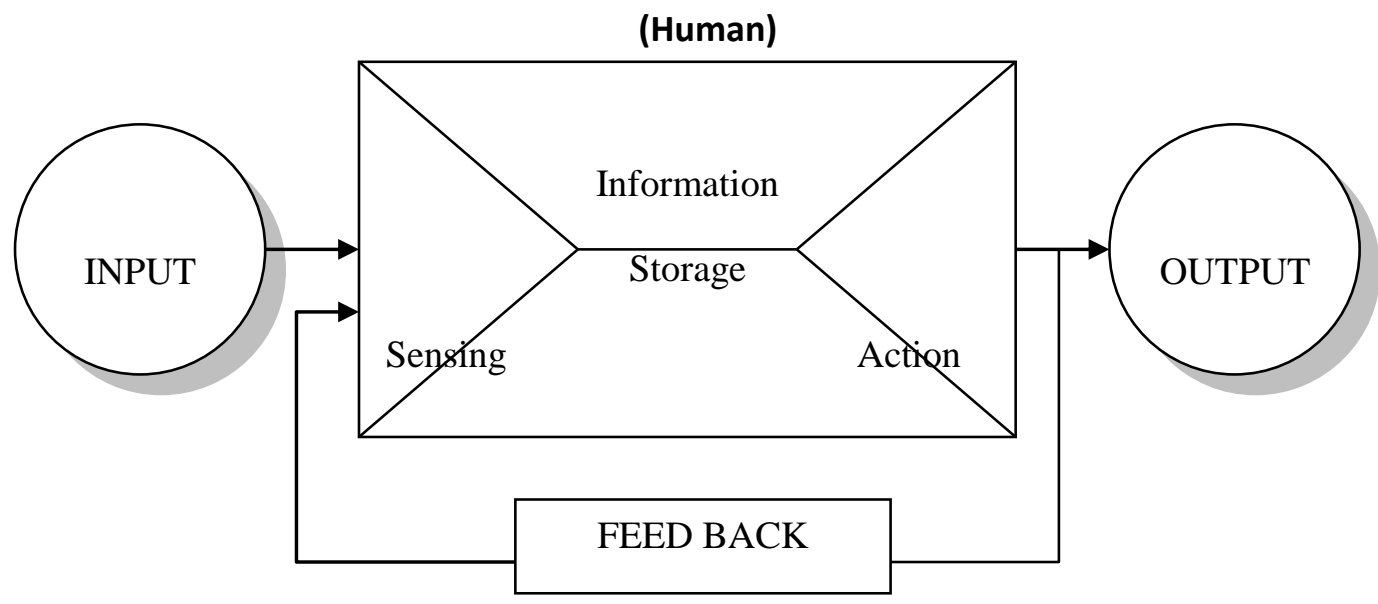

Gambar 4.1. Sistem Manusia dan Mesin Secara Manual 
Dalam sistem ini input langsung diinformasikan oleh manusia menjadi output. Dalam hal ini manusia sebagai pekerja mengendalikan sepenuhnya pekerjaan dan peralatan yang ada. Peralatan yang digunakan sekedar menambah kemampuan dan kapabilitas dalam menyelesaikan pekerjaan. Dalam sistem ini manusia sebagai operator sebagai sumber tenaga yang penuh dan harus menggunakan keterampilannya dalam menyelesaikan pekerjaan.

\subsubsection{Sistem Manusia Mesin Secara Semi Automatic}

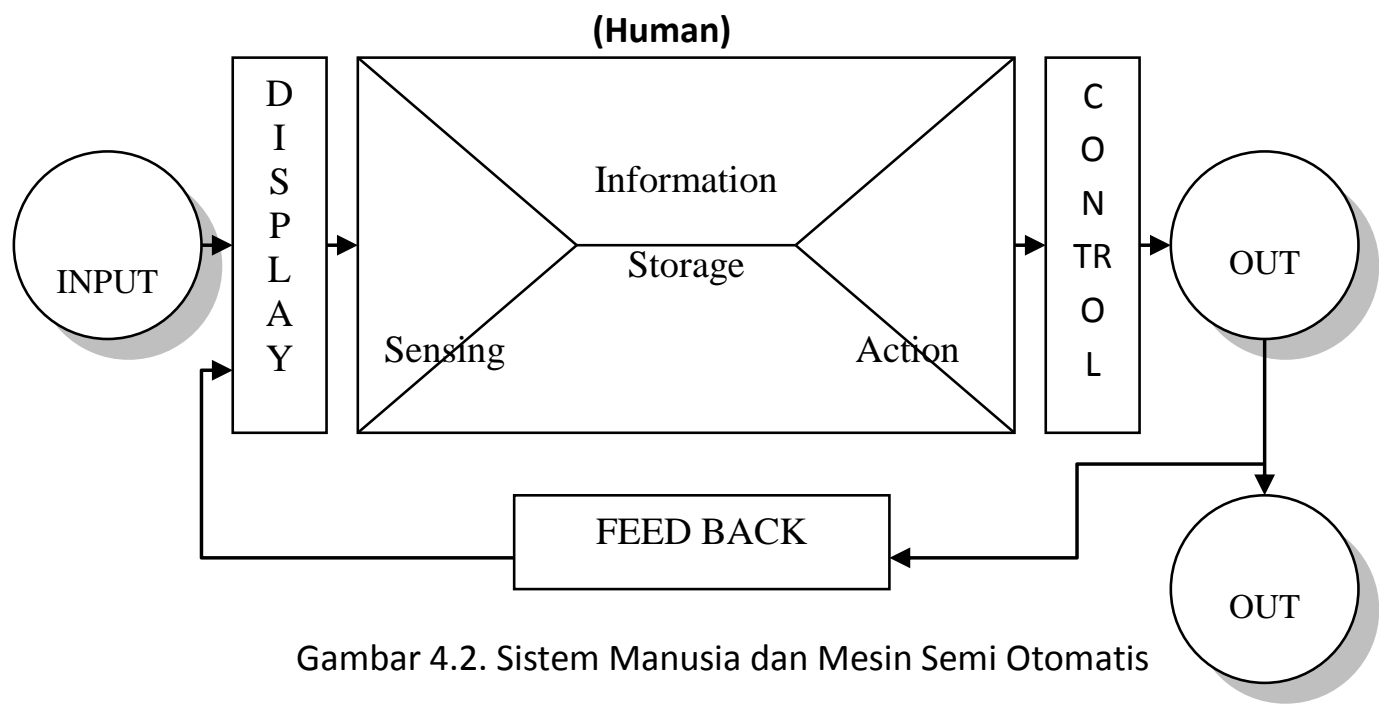

Pada hubungan kerja manusia dan mesin secara semi automatic sistem akan mengolah input dari luar sebelum masuk kedalam sistem kerja demikian pula akan dilah dan dikontrol sebelum output berhasil diproses. Dalma hal ini 
manusia sebagai pekerja tidak bisa secara langsung mengendalikan sistem yang ada, tatapi mampu melakukan control dalam sistem tersebut dengan menggunakan display atau monitor supaya sistem bekerja secara baik sedangkan mesin digunakan tenaganya dalam pekerjaan.

\subsubsection{Sistem Manusia Mesin Secara Semi Automatic}

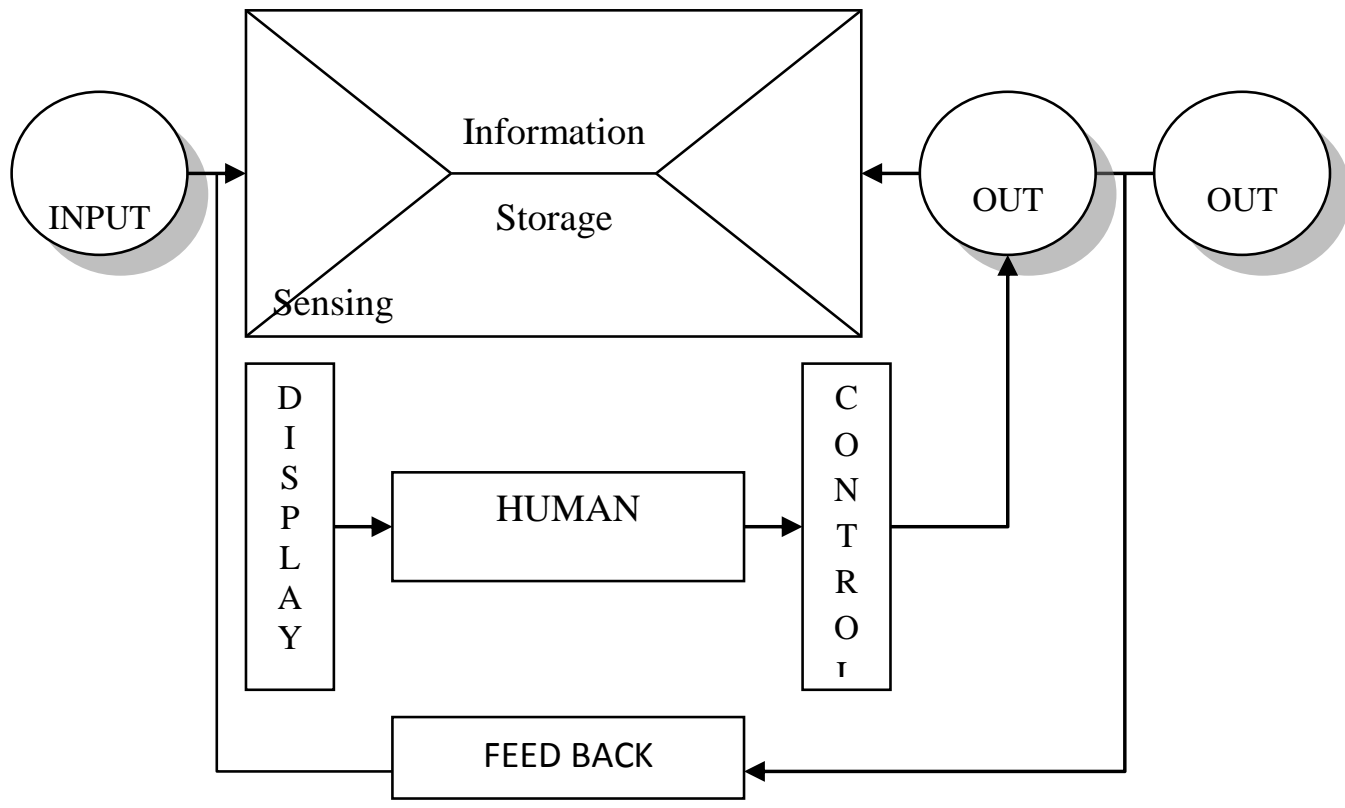

Gambar 4.3. Sistem Manusia dan Mesin Secara Otomatis

Pada sistem ini mesin melaksanakan dua fungsi yaitu menerima rangsangan dari luar dan sebagai pengendali aktifitas dalam pekerjaan. Fungsi operator hanya sebagai monitor dan menjaga mesin tetap bekerja dengan baik dan 
memasukkan data serta mengganti dengan program yang baru. Sehingga dari kesimpulan ketiga macam hubungan kerja antara manusia dan mesin masing-masing terdapat ciriciri dan karakteristik sendiri-sendiri. Dalam hal ini mesin mempunyai kelebihan dan kekurangan begitu pula manusia sebagai operator ada kelebihan dan kekurangannya.

Berikut ini perbedaan antara manusia dan mesin sebagai berikut :

Tabel 4.1. Perbedaan Manusia dengan Mesin

\begin{tabular}{|c|c|c|c|}
\hline No & Kondisi & Manusia & Mesin \\
\hline 1 & Kecepatan & Lambat & Cepat \\
\hline 2 & $\begin{array}{l}\text { Tenaga } \\
\text { (power) }\end{array}$ & $\begin{array}{l}\text { Kecil, terbatas, serta } \\
\text { berubah-ubah }\end{array}$ & $\begin{array}{l}\text { Dapat diatur dengan baik, } \\
\text { bisa besar dan tetap }\end{array}$ \\
\hline 3 & Keseragaman & $\begin{array}{lr}\text { Tidak } & \text { dapat } \\
\text { diandalkan, } & \text { perlu } \\
\text { dimonitor } & \end{array}$ & $\begin{array}{l}\text { Seragam/ standard cocok } \\
\text { untuk pekerjaan rutin, } \\
\text { berulang-ulang dan perlu } \\
\text { ketetapan. }\end{array}$ \\
\hline 4 & $\begin{array}{l}\text { Ingatan } \\
\text { (memory) }\end{array}$ & $\begin{array}{l}\text { Bisa mengingat segala } \\
\text { pendekatan dari } \\
\text { berbagai sudut, baik } \\
\text { untuk menentukan } \\
\text { dasar-dasar pikiran } \\
\text { maupun strategi }\end{array}$ & $\begin{array}{l}\text { Baik untuk menyimpan dan } \\
\text { memproduksi sesuatu yang } \\
\text { sudah ditentukan, baik } \\
\text { untuk jangka pendek atau } \\
\text { panjang (komputer) }\end{array}$ \\
\hline 5 & Berfikir & Induktif baik & Deduktif baik \\
\hline 6 & Kalkulasi & 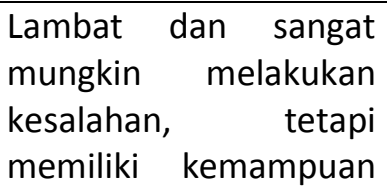 & $\begin{array}{l}\text { Cepat dan tepat, tetapi } \\
\text { tidak memiliki kemampuan } \\
\text { untuk koreksi }\end{array}$ \\
\hline
\end{tabular}




\begin{tabular}{|c|l|l|l|}
\hline 7 & $\begin{array}{l}\text { Reaksi } \\
\text { terhadap yang } \\
\text { berlebihan }\end{array}$ & Degradasi & Kerusakan tib-tiba \\
\hline 8 & Kepintaran & $\begin{array}{l}\text { Dapat menyesuaikan } \\
\text { sesuatu yang tidak } \\
\text { terduga/ yang dapat di } \\
\text { duga. Dapat meramal, } \\
\text { menganalisa dan ada hanya bisa } \\
\text { membuat keputusan }\end{array}$ & $\begin{array}{l}\text { Tidak ada, } \\
\text { memutuskan ya/ tidak } \\
\text { sesuai dengan programnya. }\end{array}$ \\
\hline
\end{tabular}

\subsubsection{Kondisi Lingkungan Kerja}

Manusia merupakan makhluk yang sempurna tetapi juga ada kekurangannya. Faktor-faktor yang mempengaruhi manusia dalam bekerja yang datangnya dari luar (ekstern) yaitu temperatur, kelembaban udara, sirkulasi udara, pencahayaan, kebisingan, getaran mekanis, bau dan warna.

\subsubsection{Suhu}

Tubuh manusia selalu mempertahankan keadaan normal tubuhnya sehingga dapat menyesuaikan diri terhadap peruahan yang terjadi diluar tubuhnya. Kemampuan menyesuaikan terhadap suhu jika tidak melebihi $20 \%$ kondisi panas dan 35\% kondisi dingin. Dalam keadaan normal tubuh manusia mempunyai suhu yang berbeda seperti mulut $37^{\circ} \mathrm{C}$, dada $35^{\circ} \mathrm{C}$ dan bagian kaki $28^{\circ} \mathrm{C}$. tubuh manusia akan menyesuaikan diri apabila kelebihan 
dan kekurangan panas. Untuk kondisi optimal manusia dalam bekerja suhu yang baik $24^{\circ}-27^{\circ} \mathrm{C}$.

\subsubsection{Kelembaban Udara}

Kelembaban udara adalah banyaknya air yang terkandung dalam udara (\%). Kelembaban udara dipengaruhi oleh suhu udara. Suhu udara yang tinggi maka kelembabannya sangat besar dan sebaliknya. Pengaruh terhadap manusia dalam bekerja adalah cepatnya denyut jantung dalam mengedarkan darah untuk memenuhi kebutuhan oksigen.

\subsubsection{Sirkulasi Udara}

Udara disekitar kita mengandung 21\% oksigen, 78\% nitrogen, $0,03 \% \mathrm{CO}_{2}$ dan $0,97 \%$ gas lain yang merupakan campuran. Oksigen dibutuhkan untuk proses metabolisme. Udara yang bersih akan berpengaruh terhadap kesehatan manusia dalam bekerja sehingga diperlukan pengaturan udara (sirkulasi) dimana udara harus bebas lewat melalui ventilasi atau jendela. Untuk mengatasi udara yang kotor maka beberapa perkantoran menggunakan pendingin udara yang disebut AC (Air Conditioning). 


\subsubsection{Pencahayaan}

Cahaya mempengaruhi kerja manusia dalam melihat objek pekerjaan sehingga tidak menimbulkan kesalahan. Pencahayaan yang kurang baik akan mengakibatkan mata cepat lelah dan berakomodasi dengan keras. Kemampuan mata untuk melihat dengan jelas ukuran objek, derajat kontras dan lamanya waktu melihat obyek tergantung dari intensitas atau penerangan cahaya dari sebuah sumber cahaya. Cahaya yang sangat kuat penerangannya akan menimbulkan silau sehingga mata menimbulkan salah persepsi terhadap objek.

\subsubsection{Kebisingan}

Kebisingan pada dewasa ini merupakan suatu polusi. Suara atau bunyian yang melebihi ambang telinga kita dinamakan bising. Kebisingan yang terus-menerus akan mengakibatkan rusaknya alat pendengaran. Tidak mampunya alat pendengaran menerima suara atau bunyi dinamakan tuli. Intensitas atau besarnya arus energi suara diukur dengan satuan Desibel (dB). Gelombang suara atau bunyi diukur dengan satuan Hertz atau $\mathrm{Hz}$.

\subsubsection{Getaran Mekanis}

Getaran mekanis berlebihan akan mengganggu manusia dalam bekerja. Gangguan tersebut seperti konsentrasi 
kerja berkurang, cepat lelah dan mempengaruhi saraf otak dalam berfikir :

Tabel 4.2. Besaran nilai Kebisingan (dB)

\begin{tabular}{|c|c|c|}
\hline Kondisi & Desibel (dB) & Batas Dengar Tertinggi \\
\hline Menuliskan & $\begin{array}{l}120 \\
110 \\
100\end{array}$ & $\begin{array}{l}\text { Halilintar } \\
\text { Meriam } \\
\text { Mesin uap }\end{array}$ \\
\hline Sangat hiruk pikuk & $\begin{array}{l}90 \\
80\end{array}$ & $\begin{array}{l}\text { Jalan hiruk pikuk } \\
\text { Perusahaan sangat gaduh } \\
\text { Pluit polisi }\end{array}$ \\
\hline Kuat & $\begin{array}{l}70 \\
60 \\
\end{array}$ & $\begin{array}{l}\text { Rumah gaduh } \\
\text { Jalan pada umumnya } \\
\text { Radio } \\
\text { Perusahaan }\end{array}$ \\
\hline Sedang & $\begin{array}{l}50 \\
40\end{array}$ & $\begin{array}{l}\text { Rumah gaduh } \\
\text { Kantor pada umumnya } \\
\text { Percakapan kuat } \\
\text { Radio peralatan } \\
\end{array}$ \\
\hline Tenang & $\begin{array}{l}30 \\
20\end{array}$ & $\begin{array}{l}\text { Rumah tenang } \\
\text { Kantor pribadi } \\
\text { Auditorium } \\
\text { Percakapan }\end{array}$ \\
\hline Sangat tenang & $\begin{array}{l}10 \\
0\end{array}$ & $\begin{array}{l}\text { Suara diam-diam } \\
\text { Berbisik } \\
\text { Batas dengan terendah }\end{array}$ \\
\hline
\end{tabular}

\subsubsection{Bau}

Bau-bauan termasuk juga polusi yang mempengaruhi konsentrasi seseorang dalam bekerja. Hal ini dipengaruhi 
oleh angin atau udara yang bertiup sehingga sampai kehidung manusia untuk mempengaruhi hal-hal tersebut maka manusia menciptakan aroma bau yang dapat meningkatkan kepekaan penciuman. Keadaan demikian bisa juga dengan memakai $A C$ untuk meredam atau mengurangi bau yang tidak sedap.

\subsubsection{Warna}

Warna yang mempengaruhi seseorang dalam bekerja adalah interior ruangan dalam hal ini tembok. Hal ini karena tembok dapat memantulkan cahaya yang diterima maupun dapat menyerap cahaya tersebut. Warna-warna yang mempengaruhi antara lain :

a. Merah bersifat panas dan tajam

b. Kuning bersifat terang dan luas

c. Hijau dan biru bersifat sejuk dan segar

d. Gelap atau hitam bersifat sempit

Warna-warna tadi memberikan kesan psikologis yang menguntungkan dan juga merugikan.

\section{$\underline{\text { Soal }}$}

Buatlah contoh hubungan kerja antara manusia dengan mesin dan jelaskan proses kerjanya! 


\section{BAB. 5}

\section{ALAT PERAGA / DISPLAY DAN SISTEM PENGENDALIAN MESIN}

Didalam industri modern manusia dalam bekerja dibantu oleh mesin dan peralatan untuk mengarahkan dan mengendalikan pekerjaan yang akan dilakukan oleh mesin. Operator menerima informasi dari mesin kemudian mengambil keputusan untuk memerintah mesin melakukan perubahanperubahan. Untuk itu diperlukan beberapa alat peraga atau display maupun instrument untuk menjalankan, memerintah dan mengendalikan mesin.

\subsection{Pengaturan Informasi}

Ada tiga instumen peraga atau display instumen yang diproduksi secara masal yaitu :

a. Jendela terbuka, dimana angka dapat dibaca secara langsung

b. Cakra atau Dial yang bentuknya bulat dengan jarum yang bergerak

c. Jarum yang tetap tetapi cakra atau dial yang bergerak.

Masing-masing tipe peraga/ display memiliki kelebihan serta kekurangan sendiri-sendiri. Kalau hanya untuk 
mengetahui angka maka metode jendela terbuka lebih cocok tetapi angkanya perlu nampak. Jika proses urutan berubah yang harus diamati maka jarum bergerak dengan cakra atau dial bulat lebih baik.

Tabel 5.1. Jenis Display

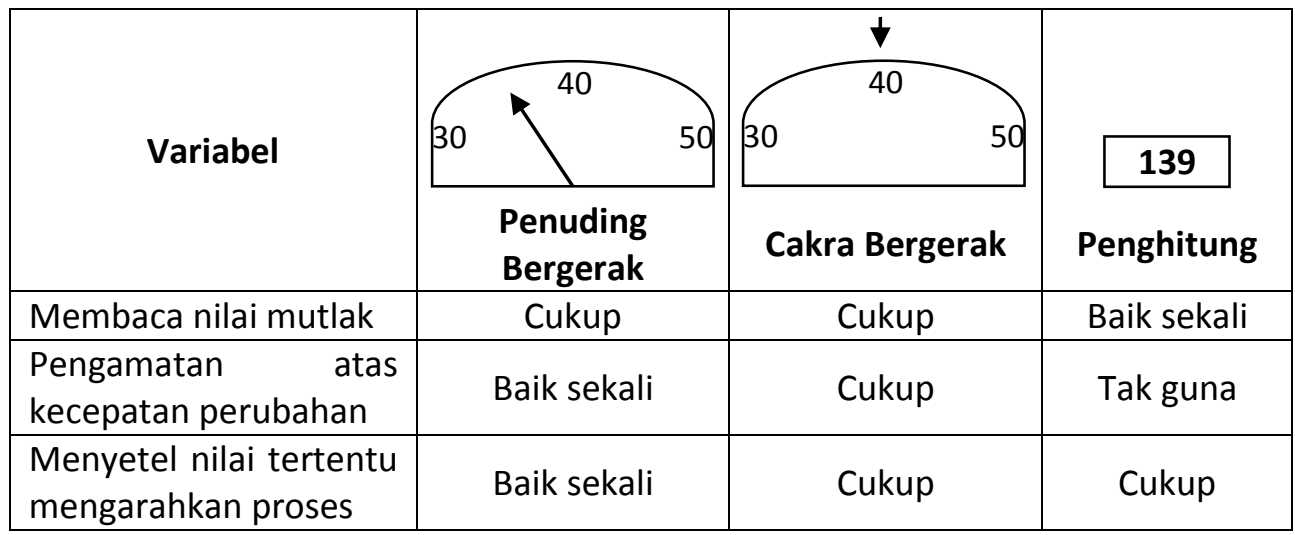

\subsection{Cakra atau Dial}

Persyaratan untuk membuat tipe instrument atau peraga bentuk cakra atau dial sebagai berikut :

1. Derajat kecermatan harus sesuai dengan kecermatan yang diinginkan. Cakra yang menghasilkan kecermatan lebih besar akan membuat pembacaan lebih sulit sehingga terjadi kesalahan.

2. Cakra harus menyampaikan dengan jelas kepada operator mesin untuk menghindari kesalahan informasi 
3. Cakra harus memberi informasi lebih detail tentang angka yang akan dipakai.

4. Skala yang baik untuk pembuatan cakra atau dial adalah kelipatan 1, 2, dan 5.

5. Angka harus dipasang pada tanda skala yang besar saja.

6. Pada skala tetap angka sebaiknya tegak

7. Ukuran tanda skala harus disesuaikan dengan jarak pembacaan.

8. Ujung dari penuding tidak boleh menutupi tanda angka maupun skala
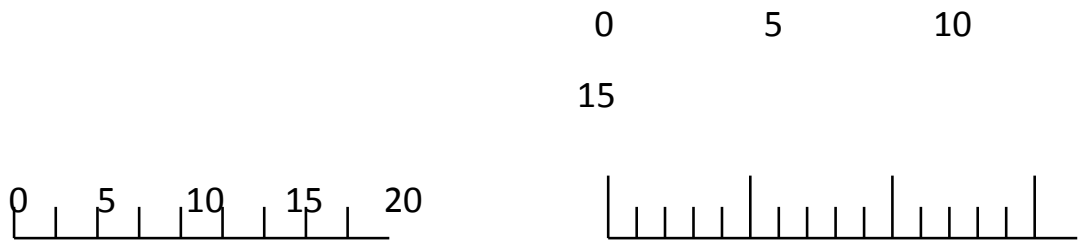

Salah

Benar

\subsection{Huruf dan Angka}

Seperti halnya pada tanda dan skala ukuran hurf dan angka harus sesuai dengan jarak yang diperkirakan antara mata dan display informasinya. 
Tinggi huruf atau angka dalam $\mathrm{mm}=\frac{\text { Jarak Visual dalam } \mathrm{mm}}{200}$

Contoh :

Jarak visual dalam $\mathrm{cm}$

Tinggi huruf kecil atau angka dalam

$\begin{array}{cc}\text { Sampai } 50 & 0,25 \\ 50-90 & 0,5 \\ 90-180 & 0,9 \\ 180-360 & 1,8 \\ 360-600 & 3,0\end{array}$

Huruf besar pada awal diikuti huruf kecil lebih mudah dibaca daripada huruf besar semua. Bagi kebanyakan huruf dan angka perbandingan yang baik sebagai berikut :

Lebar sebaiknya $2 / 3$ dari tinggi, jarak antara 2 huruf sebaiknya $1 / 4$ dari jarak tinggi, jarak antara huruf dan angka sebaiknya $1 / 5$ dari tinggi.

\subsection{Tipe Pengendalian Mesin}

Ada bermacam-macam tipe pengendalian mesin yang dioperasikan oleh perusahaan yaitu :

- Bentuk tombol atau knop

- Bentuk pengungkit

- Bentuk roda tangan atau pedal 
Syarat pembuatan tipe pengendalian mesin adalah sebagai berikut :

1. Tipe pengendali mesin harus cocok dengan fungsi dan anatomi anggota tubuh. Biasanya menggunakan jari, tangan, lengan dan kaki.

2. Pengendalian mesin harus diletakkan pada jarak yang mudah diraih. Ketinggiannya antara siku dan bahu.

3. Jarak antara pengendali harus sebanding dengan pertimbangan anatomi tubuh

4. Untuk pengendali jarak paling sedikit $15 \mathrm{~mm}$ dan pengendali tangan paling sedikit $50 \mathrm{~cm}$

5. Bagi operasi dengan energi rendah bertahap dan continue maka tombol tekan, saklar lebih cocok.

6. Untuk operasi dengan energi tinggi dan persisi yang rendah cocok menggunakan pengungkit lengan panjang, engkol, roda tangan dan pedal.

\subsection{Pengendalian Pekerjaan Ringan}

Sistem tombol tekan memerlukan ruangan yang kecil dan mudah dibedakan dengan memakai tanda yang berwarna. Permukaannya harus cembung dan diameternya cukup besar untuk jari tangan guna memejet tombol dengan ringan tanpa meleset. Ukuran tombol yang dianjurkan pada tombol tekan adalah : 
Diameter 12-15 mm, untuk berhenti darurat 30-40 $\mathrm{mm}$, untuk menggerakkan 3-10 mm dan untuk ketahanan 250$500 \mathrm{gr}$.

Sistem saklar mudah dan menjamin kecermatan dalam pengendalian. Dia harus mempunyai 2 posisi yaitu Off dan On serta mudah ditandai diatas atau dibawah towelnya.

Sistem tombol putar atau knop, bentuknya ada yang bulat, balok, dan runcing. Apapun bentuknya harus mudah diraba dan mempunyai pegangan yang handal. Setiap gerakan harus jelas dan tampak. Bagi tombol putar bentuk balok lancip diameternya 25-30 $\mathrm{mm}$.

Bagi tombol putar, untuk mengendalikan fungsi continue tombol memakai jari atau seluruh tangan sesuai dengan pengeluaran energi yang dibutuhkan. Berikut ini ukuran tombol putar yang baik, yaitu diameter memakai 2 atau 3 jari 10-30 mm, diameter memakai seluruh tangan 35-75 mm, kedalaman bila memakai jari 12-25 mm dan tenaga putar maksimal apabila tombol kecil $450 \mathrm{gr} \mathrm{cm}$ serta tenaga putar maksimal dengan tombol besar $2500 \mathrm{gr} \mathrm{cm}$.

Sistem engkol cocok untuk gerakan yang bertahap dan continue yang meliputi jangkauan yang lebar. Berdasarkan penyesuaian yang diperlukan maka rasio gigi dapat dipilih. Untuk gerakan cepat pegangannya harus bebas berputar pada sumbunya. Bagi penyesuaian yang persisi maka gagang yang 
tetap lebih baik. Ukuran engkol yang baik adalah : panjang lengan pada tenaga putar rendah 60-120 mm (sampai 200 rpm), panjang lengan pada tenaga putar tinggi $150-220 \mathrm{~mm}$ (sampai $160 \mathrm{rpm}$ ). Untuk gerakan yang cepat panjang lengan maksimal $120 \mathrm{~mm}$ dengan tenaga putar 0,9-2,5 kgm/cm. bagi penempatan posisi yang tepat panjang lengan 120-200 mm dan tenaga putar $1-3,5 \mathrm{kgm} / \mathrm{cm}$.

Sistem roda tangan dianjurkan untuk persyaratan kekuatan yang besar karena memakai 2 tangan dan lengan yang relatif panjang mudah dikerjakan. Sistem ini untuk kecepatan putar yang lambat.

Sistem pedal dipakai untuk pengeluaran energi yang besar. Bila diperlukan sandaran punggung yang tinggi dan posisi kaki hampir horizontal. Tekukan sendi lutut $135^{\circ}-160^{\circ}$, tekukan sendi tungkai $90^{\circ}$.

\section{Soal}

1. Sebutkan macam-macam alat instrument peraga atau display yang anda ketahui kalau perlu dengan gambar.

2. Jelaskan ukuran dari huruf dan angka apabila mendisain sebuah peralatan. 


\section{BAB. 6}

\section{METODE SAMPLING KERJA (Work Sampling)}

\subsection{Metode Work Sampling}

Metode work sampling adalah suatu prosedur pengukuran yang dilakukan dengan melakukan kunjungan-kunjungan pada waktu tertentu yang ditentukan secara acak atau random. Kunjungankunjungan dilakukan untuk mengetahui apa yang terjadi atau kegiatan apa yang sedang dilakukan di tempat kerja yang bersangkutan, frekuensi kegiatan tersebut, dan berapa persen waktu yang dipergunakan untuk pekerjaan ini. Semakin banyak kunjungan yang dilakukan semakin kuat dasar untuk mengambil kesimpulan. Agar kesimpulan yang diambil lebih tepat diperlukan teknik tertentu secara statistik yang dikenal sebagai sampling menduga perbandingan populasi.

Metode work sampling sangat baik digunakan dalam melakukan pengamatan pekerjaan yang sifatnya tidak berulang dan memiliki waktu yang relatif panjang. Pada dasarnya prosedur pelaksanaannya cukup sederhana yaitu melakukan pengamatan aktivitas kerja untuk selang waktu yang diambil secara acak terhadap satu atau lebih mesin atau operator dan kemudian mencatatnya apakah mereka dalam keadaan bekerja atau menganggur. 
Metode work sampling ini dikembangkan berdasarkan hukum probabilitas, oleh karena itu pengamatan suatu objek tidak perlu dilaksanakan secara menyeluruh melainkan cukup dilakukan dengan menggunakan sampel yang diambil secara acak atau random. Suatu sampel yang diambil secara acak dari suatu populasi yang besar akan cenderung memiliki pola distribusi yang sama seperti halnya yang dimiliki oleh populasi tersebut (Astuti, 2016).

\subsection{Tabel Bilangan Acak}

Metode sampling kerja sangat cocok di gunakan dalam melakukan pengamatan atas pekerjaan yang sifatnya tidak berulang dan memiliki siklus waktu yang relatif panjang. Prosedur penggunaannya cukup sederhanayaitu melakukan pengamatan aktivitas kerja untuk selang waktu yang diambil secara acak terhadap satu atau lebih mesin atau operator tersebut dalam keadaan bekerja ataupun menganggur. Pengukuran waktu dimulai dari pengamatan pendahuluan kemudian menentukan bilangan acak untuk mengambil waktu kunjungan dengan mengambil data sampel secara acak.Sebelum melakukan perhitungan atau menentukan aktivitas pegawai maka lebih dahulu menentukan bilangan acak atau randomyang berfungsi untuk mengetahui selang waktu kunjungan (Veza, 2017). 


\begin{tabular}{|c|c|c|c|c|c|c|c|c|c|c|c|c|c|c|}
\hline & & & & Ta & el & Bil & ns & an & 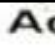 & $\mathbf{k}$ & & & & \\
\hline 19 & 90 & 69 & 64 & 61 & 20 & 26 & 36 & 34 & 62 & 58 & 24 & 97 & 14 & 97 \\
\hline 65 & 97 & 60 & 12 & 11 & 31 & 56 & 34 & 19 & 19 & 47 & 83 & 75 & 51 & 33 \\
\hline 51 & 67 & 47 & 97 & 19 & 98 & 40 & 07 & 17 & 66 & 23 & os & 09 & 51 & 80 \\
\hline 17 & 95 & 21 & 78 & 58 & 24 & 33 & 45 & 77 & 48 & 69 & 81 & 84 & 09 & 29 \\
\hline 63 & 52 & 06 & 34 & 30 & 01 & 31 & 60 & 10 & 27 & 35 & 07 & 79 & 71 & 53 \\
\hline 85 & 53 & 83 & 20 & 95 & 56 & 27 & 09 & 24 & 43 & 21 & 78 & 59 & 09 & 82 \\
\hline 37 & 79 & 49 & 12 & 38 & 48 & 13 & 93 & 55 & 96 & 41 & 92 & 45 & 71 & 51 \\
\hline 69 & $\infty$ & 39 & 59 & 24 & 00 & 06 & 41 & 41 & 20 & 14 & 36 & 59 & 25 & 47 \\
\hline 76 & 62 & 16 & 48 & 68 & 58 & 76 & 17 & 14 & B6 & 59 & 53 & 11 & 52 & 21 \\
\hline 71 & 82 & 13 & 50 & 41 & 27 & 55 & 10 & 24 & 92 & 28 & 04 & 67 & $53=$ & 44 \\
\hline 34 & 28 & 0.4 & 52 & 35 & 74 & 13 & 39 & 35 & 22 & $6 n$ & 95 & 23 & 92 & 35 \\
\hline 21 & 20 & 99 & 45 & 18 & 76 & 51 & 94 & 84 & 86 & 13 & 79 & 93 & 37 & ss \\
\hline 27 & 37 & 83 & $2 n$ & 71 & 79 & 57 & 95 & 13 & 91 & 09 & 64 & 87 & 25 & 21 \\
\hline 10 & 65 & Bi & 92 & 59 & 77 & 31 & 61 & 95 & 46 & 20 & 44 & 90 & 32 & 64 \\
\hline 59 & 71 & 74 & 17 & 32 & 48 & 38 & 75 & 93 & 29 & 73 & 37 & 32 & 04 & os \\
\hline 87 & 63 & 93 & 95 & 17 & BI & 83 & 83 & 04 & 49 & 77 & 45 & 85 & & 51 \\
\hline On & 61 & 74 & 51 & 69 & 92 & 79 & 43 & R9 & 79 & 29 & 18 & 94 & 51 & 23 \\
\hline$O s$ & 57 & 65 & 08 & 40 & 48 & 40 & 35 & 94 & 22 & 72 & 65 & 71 & os & 86 \\
\hline B9 & AS & 8.4 & 46 & 06 & 64 & 78 & 96 & 21 & 66 & B9 & 37 & 20 & 70 & or \\
\hline 42 & 29 & 72 & 23 & 19 & 06 & 94 & 76 & 10 & OB & 81 & 30 & Is & 30 & 14 \\
\hline 79 & 53 & 36 & on & 95 & 94 & 61 & or & 43 & 62 & 20 & 21 & 34 & 68 & 86 \\
\hline 79 & 93 & 96 & 38 & 63 & 34 & 85 & 52 & os & $\infty$ & 85 & 43 & 01 & 72 & 73 \\
\hline 97 & 48 & 72 & 66 & 48 & 53 & 16 & 71 & 13 & 81 & 59 & 97 & 50 & 99 & 52 \\
\hline 26 & 97 & os & 73 & 51 & 88 & 46 & $3 \mathbf{n}$ & 03 & 58 & 72 & 68 & 49 & 29 & 31 \\
\hline 06 & 87 & 37 & 78 & $4 n$ & -65 & $8 d$ & 69 & $\sin$ & 39 & 88 & $\alpha z$ & 84 & 27 & 83 \\
\hline 87 & oz & 22 & 57 & 51 & 68 & 69 & 80 & 95 & 44 & 17 & 29 & or & 95 & 80 \\
\hline 39 & 77 & 32 & 77 & 09 & 79 & 57 & 92 & 36 & 59 & 89 & 74 & 39 & $\mathrm{~Hz}$ & 15 \\
\hline 28 & 06 & 24 & 25 & 93 & 22 & 45 & 44 & 84 & 11 & 87 & Bo & 61 & 65 & 11 \\
\hline 97 & 67 & 63 & 99 & 61 & 80 & 45 & 67 & 93 & 82 & 59 & 73 & 19 & 85 & 23 \\
\hline 69 & 30 & 16 & 09 & os & 53 & 58 & 47 & 70 & 93 & 66 & 56 & 45 & 65 & 79 \\
\hline 33 & 73 & 99 & 19 & 87 & 26 & 72 & 39 & 27 & 67 & 53 & 77 & 57 & 68 & 93 \\
\hline 87 & 14 & 77 & 43 & 96 & 43 & 00 & 65 & $9 n$ & 50 & 45 & 60 & 33 & oi & o7 \\
\hline 99 & 53 & 93 & 61 & 28 & 52 & 70 & os & $4 r$ & 34 & 56 & 65 & os & 61 & $B 6$ \\
\hline 93 & 86 & 52 & 77 & 65 & 15 & 3.3 & 50 & os & 28 & 22 & 87 & 26 & 07 & 47 \\
\hline 18 & 46 & 23 & 34 & 27 & ns & 13 & 99 & 24 & 44 & 49 & 18 & $\infty$ & 79 & 49 \\
\hline 07 & 10 & 63 & 76 & 35 & 67 & 03 & 04 & 79 & HR & On & 18 & 18 & R5 & 31 \\
\hline 92 & 38 & 70 & 96 & 92 & 52 & 06 & 79 & 79 & 45 & A2 & 6.3 & 18 & 27 & 44 \\
\hline 00 & 57 & 25 & 60 & 59 & 46 & 72 & 60 & IR & 77 & 55 & 66 & 12 & 62 & 11 \\
\hline 24 & 98 & 65 & 63 & 21 & 47 & 21 & 61 & คB & 32 & 27 & но & 30 & 21 & 60 \\
\hline 28 & 10 & 99 & 00 & 27 & 12 & 73 & 73 & 99 & 12 & 49 & 99 & 57 & 94 & 82 \\
\hline
\end{tabular}

Gambar 6.1. Tabel Bilangan Acak Sumber: Sutalaksana $(1979,187)$ 


\subsection{Menentukan Jumlah Pengamatan}

Menurut Wignjosoebroto (2006), banyaknya pengamatan yang harus dilakukan dalam sampling kerja akan dipengaruhi oleh 2 faktor utama, yaitu :

a. Tingkat Ketelitian (Degree Of Accuracy) dan hasil pengamatan.

b. Tingkat Kepercayaan (Level Of Convidence) dari hasil pengamatan.

Dengan asumsi bahwa terjadinya kejadian seorang operator akan bekerja atau menganggur mengikuti pola distribusi normal, maka untuk mendapatkan jumlah sample pengamatan yang harus dilaksanakan dapat dicari berdasarkan rumus berikut :

$$
S p=k \sqrt{\frac{1(1-p)}{N}}
$$

Sumber :Wignjosoebroto,2006

Keterangan:

$\mathrm{Sp} \quad=$ Tingkat ketelitian yang dikehendaki dan dinyatakan dalam desimal

$\mathrm{p}=$ Prosentase kejadian yang diamati dan dinyatakan dalambentuk desimal

$\mathrm{N} \quad=$ Jumlah pengamatan yang harus dilakukan untuk sampling kerja

k = =Harga indeks yang besarnya tergantung tingkat kepercayaan yang diambil 
Untuk tingkat kepercayaan $68 \%$ harga k adalah 1 Untuk tingkat kepercayaan $95 \%$ harga k adalah 2 Untuk tingkat kepercayaan 99 \% harga k adalah 3

\subsection{Uji Kecukupan Data}

Dari pengamatan dan uji kecukupan data untuk setiap operator, apakah data pengamatan yang dilakukan telah mencukupi atau tidak. Jika pengamatan seharusnya dilakukan ( $\left.\mathrm{N}^{\prime}\right)$ lebih kecil dari jumlah pengamatan yang dilakukan $(N)\left(N^{\prime} \leq N\right)$ maka data telah mencukupi dan pengamatan dihentikan (Veza, 2017). Dengan menggunakan rumus sebagai berikut:

$$
\mathrm{N}^{\prime}=\frac{k^{2}\left(1-p^{2}\right)}{s^{2} p}
$$

Sumber: Veza, 2017

Keterangan:

$\mathrm{p} \quad=$ Jumlah produktif

$\mathrm{N}^{\prime} \quad$ = Jumlah pengamatan hasil perhitungan

$\mathrm{k}=$ Tingkat kepercayaan

$\mathrm{s} \quad=$ Tingkat ketelitian

\subsection{Uji keseragaman Data}

Untuk mengetahui apakah data yang diperoleh sudah seragam atau belum, yang ditandai dengan tidak adanya data yang keluar dari batasan (out of control) (Veza, 2017). 


\section{a. BKA (Batas Kontrol Atas)}

Untuk menghitung Batas Kontrol Atas (BKA) dengan menggunakan persamaan:

$$
\mathrm{BKA}=\mathrm{p}+\mathrm{k} \sqrt{\frac{p(1-p)}{n}}
$$

Sumber: Veza, 2017

Keterangan:

$\mathrm{p} \quad=$ Presentase produktif

$\mathrm{n} \quad=$ Jumlah pengamatan

$\mathrm{k} \quad=$ Tingkat kepercayaan

b. BKB (Batas Kontrol Bawah)

Untuk menghitung Batas Kontrol Bawah (BKB) dengan menggunakan persamaan:

$$
\mathrm{BKB}=\mathrm{p}-\mathrm{k} \sqrt{\frac{p(1-p)}{n}}
$$

Sumber: Veza, 2017

Keterangan:

$\mathrm{p} \quad=$ Presentase produktif

$\mathrm{n}=$ Jumlah pengamatan

$\mathrm{k}=$ Tingkat kepercayaan 


\subsection{Perhitungan Waktu Baku}

Menurut Jono (2015), waktu baku adalah waktu seluruhnya untuk menyelesaikan suatu pekerjaan pada prestasi standar.Langkah-langkah yang dilakukan dalam menghitung waktu baku adalah :

a. Menentukan jumlah kunjungan terhadap seluruh pekerja yang akan diamati.

b. Menentukan jumlah pengamatan produksi dan prosentase produktifnya.

c. Menetapkan jumlah menit pengamatan yang dilakukan selama pengamatan berlangsung.

d. Menghitung jumlah produk yang dihasilkan selama pengamatan.

e. Menghitung waktu siklus.

f. Menghitung waktu normal dengan memasukkan faktor penyesuaian.

g. Menghitung waktu baku dengan memasukkan faktor kelonggaran yang telah ditetapkan.

Menurut Jono (2015), rumus yang digunakan untuk menghitung waktu baku adalah sebagai berikut :

$$
\text { Waktu Baku }=\text { Waktu Normal } x \frac{100 \%}{100 \%-\text { Kelonggaran } n(\%)}
$$

Sumber: Jono, 2015 


\subsection{Presentase Produktif}

Menurut Veza (2017), prosentase produktif didapatkan dari jumlah pengamatan produktif dibagi jumlah pengamatan aktivitas kerja. Adapun perhitungan prosentase produktif adalah:

$$
\text { Presentase Produktif }=\frac{\sum \text { produktif }}{n} \times 100 \%
$$

Sumber: Veza, 2017

Keterangan:

Presentase produktif = Tingkat kinerja

n

= Jumlah pengamatan

$\Sigma$ produktif = Jumlah total produktif selama pengamatan

\subsection{Presentase Non-Produktif}

Menurut Wignjosoebroto (2006), rumus untuk mencari presentase non produktif adalah sebagai berikut:

$$
\text { Presentase non produktif }=\frac{\text { jumlah non produktif }}{\text { Jumlah pengamatan }} \times 100 \%
$$

Sumber: Wignjosoebroto, 2006

\subsection{Ratio delay}

Ratio delay didapatkan dengan menggunakan rumus sebagai berikut:

$$
\text { Ratio delay }=\frac{\% \text { non produktive }}{\% \text { produktive }}
$$

Sumber: Santoso, 2016 


\subsection{Performance Level}

Perfomance leveldidapatkan dengan menggunakan rumus sebagai berikut Performance level $=\frac{\text { Jumlah produktif }}{\text { Produktif }+ \text { non produktif }} \times 100 \%$

Sumber: Wignjosoebroto, 2006

\subsection{Jumlah Menit Produktif (JMP)}

Menghitung jumlah menit produktif adalah menghitung banyaknya menit produktif yaitu dengan cara presentase produktif dikali dengan jumlah menit pengamatan. Dihitung dengan rumus:

$\mathrm{JMP}=$ Presentase Produktif $\times$ Jumlah menit Pengamatan

Sumber: Rafian, 2017

\subsection{Penentuan Besaran Satuan Waktu}

Penentuan satuan waktu merupakan langkah yang sangat penting dalam melakukan metode sampling kerja, hal ini disebabkan karena penentuan satuan waktu merupakan dasar penentuan banyaknya jumlah pengamatan yang akan dilakukan. Di bawah ini merupakan contoh cara penentuan besaran satuan waktu:

1. 1 shift $=1$ jam $=60$ menit $=3600$ detik.

2. 1 kali pengamatan $=65$ detik. 
3. Nilai satuan waktu $=\frac{3600}{65}=55$ satuan waktu.

4. Tabel bilangan acak.

\begin{tabular}{|l|l|l|l|l|}
\hline 68 & 69 & 80 & 95 & 44 \\
\hline 79 & 57 & 92 & 36 & 59 \\
\hline 22 & 45 & 44 & 84 & 11 \\
\hline 80 & 45 & 67 & 93 & 82 \\
\hline 53 & 58 & 74 & 70 & 93 \\
\hline
\end{tabular}

\begin{tabular}{|l|l|l|l|l|}
\hline 79 & 53 & 36 & 02 & 95 \\
\hline 79 & 93 & 96 & 38 & 63 \\
\hline 97 & 48 & 72 & 66 & 48 \\
\hline 26 & 97 & 05 & 73 & 51 \\
\hline 06 & 87 & 37 & 78 & 48 \\
\hline
\end{tabular}

5. Mengeliminasi angka yang sama dari tabel bilangan acak (random).

\begin{tabular}{|c|c|c|c|c|}
\hline 68 & 69 & 80 & 95 & 44 \\
\hline 79 & 57 & 92 & 36 & 59 \\
\hline 22 & 45 & 44 & 84 & 11 \\
\hline 80 & 45 & 67 & 93 & 82 \\
\hline 53 & 58 & 74 & 70 & 93 \\
\hline
\end{tabular}

\begin{tabular}{|l|l|l|l|l|}
\hline 79 & 53 & 36 & 02 & 95 \\
\hline 79 & 93 & 96 & 38 & 63 \\
\hline 97 & 48 & 72 & 66 & 48 \\
\hline 26 & 97 & 05 & 73 & 51 \\
\hline 06 & 87 & 37 & 78 & 48 \\
\hline
\end{tabular}

6. Urutkan angka terkecil sampai terbesar yang tidak melebihi nilai kunjungan.

$02,05,06,11,22,26,36,37,38,44,45,47,48,51,53$.

7. Menentukan jam kunjungan. 
8. Menentukan status operasi.

Soal

Tentukan waktu kunjungan penelitian pada sebuah perusahaan, dimana jam kerja dimulai pukul 7.00 pagi dan berakhir pada 15.00 sore. Jam istirahat diberikan pada pukul 12.00 sampai 13.00 . Waktu yang dibutuhkan selama satu kali pengamatan selama 7 menit. 


\section{BAB. 7}

\section{ANTHROPOMETRI}

\subsection{Anthropometri}

Ketika kita membahas pentingnya kenyamanan dalam kegiatan sehari-hari, kita tahu apabila tubuh juga memerlukan kenyamanan tersebut untuk melakukan fungsi-fungsi organ tubuh seperti pergerakan tubuh dan efeknya bagi tubuh. Dalam pengkajian kenyamanan suatu produk tersebut yang harus kamu perhatikan salah satunya yaitu dengan cara pengukuran. Pengukuran terhadap tubuh manusia inilah yang nantinya kita sebut dengan ilmu antropometri.

Anthropometri merupakan satu kumpulan data numerik yang berhubungan dengan dengan karakteristik fisik tubuh manusia, ukuran, bentuk dan kekuatan serta penerapan dari data tersebut untuk penanganan masalah desain. Anthropometri juga biasanya pertimbangan ergonomis dalam proses perencanaan produk maupun sistem kerja yang memerlukan interaksi pada manusia.

Data anthropometri digunakan untuk berbagai keperluan seperti perancangan tempat atau area kerja (workplaces), perkakas atau fasilitas kerja, agar diperoleh ukuran - ukuran yang sesuai dan layak dengan dimensi ukuran anggota tubuh manusia yang akan 
menggunakannya. Dalam pengukuran di anthropometri membutuhkan suatu alat yang dapat digunakan untuk merancang atau membantu pekerjaan manusia agar lebih mudah, ringan, nyaman dalam melakukan suatu pekerjaan.

Menurut Sokhibi (2017), anthropometri adalah suatu bagian yang mendukung ergonomi, terutama dalam perancangan peralatan berdasar prinsip ergonomi. "anthropometri" berasal dari kata "anthro" yang artinya manusia, dan "metri" yang artinya ukuran. Sehingga, "anthropometri" adalah ilmu tentang hubungan antara struktur dan fungsi tubuh (termasuk bentuk dan ukuran tubuh) dengan desain alat-alat yang digunakan manusia.

Data anthropometri yang berhasil diperoleh akan diaplikasikan secara luas antara lain dalam hal:

1. Perancangan area kerja (work station, interior mobil, dan lainlain).

2. Perancangan peralatan kerja seperti mesin, equipment, perkakas (tools) dan lain sebagainya.

3. Perancangan produk konsumtif seperti pakaian, kursi/meja komputer, dan lain-lain.

4. Perancangan lingkungan kerja fisik.

\subsection{Faktor-Faktor Yang Mempengaruhi Data Anthropometri}

Menurut Wijaya (2016), terdapat berbagai macam faktor yang mempengaruhi dimensi tubuh manusia, diantaranya: 
a. Umur, ukuran tubuh manusia akan berkembang dari saat lahir sampai kira-kira berumur 20 tahun untuk pria dan 17 tahun untuk wanita. Kemudian manusia akan berkurang ukuran tubuhnya saat manusia berumur 60 tahun.

b. Jenis Kelamin, pada umumnya pria memiliki dimensi tubuh yang lebih besar daripada wanita kecuali pada bagian dada dan pinggul.

c. Suku Bangsa (etnis), variasi dimensi akan terjadi, karena pengaruh etnis. Dari hasil penelitian perbandingan karakteristik anthropometri suku Jawa dan suku Batak didapatkan hasil adanya perbedaan yang signifikan. Beberapa perbedaan antara suku Jawa dan suku Batak diantaranya, lakilaki suku Jawa cenderung memiliki jari tangan yang lebih panjang daripada laki-laki suku Batak sedangkan pada perempuan, tangan maupun lengan suku Jawa lebih panjang daripada suku Batak, pada bagian paha dan perut perempuan suku Batak memiliki ketebalan yang lebih besar serta adanya karaketiristik anthropometri bentuk kaki yang berbeda antara suku Jawa dan suku Batak. Dari penelitian ini juga didapatkan estimasi proporsi variabel anthropometri pada masing-masing suku.

d. Pekerjaan, aktivitas kerja sehari-hari juga menyebabkan perbedaan ukuran tubuh manusia. Dalam perjalanan teori 
ergonomi pekerjaan yang dilakukan secara terus menerus dapat mengakibatkan perubahan bentuk tubuh.

\subsection{Uji Kecukupan Data}

Dalam uji kecukupan data anthropometri tingkat kepercayaan yang digunakan 95\% dan tingkat ketelitian sebesar 5\%(Sokhibi 2017).

Untuk perhitungan uji kecukupan data anthropometri adalah sebagai berikut:

$$
N^{\prime}=\left[\frac{k / s \cdot \sqrt{n \cdot \Sigma \mathrm{x}^{2}-(\Sigma x)^{2}}}{\Sigma x}\right]^{2}
$$

Sumber: Wijaya, 2016

Keterangan:

$\mathrm{N}^{\prime} \quad=$ Kecukupan data

$\mathrm{N} \quad=$ Banyak data yang diukur

$\mathrm{k}=$ = Tingkat kepercayaan

$\mathrm{s} \quad=$ Derajat ketelitian 


\subsection{Uji Keseragaman Data}

Menurut Arif (2016), pengujian keseragaman data dilakukan untuk mengetahui apakah data yang kita peroleh menyebar seragam atau tidak. Rumus untuk menhitung keseragaman data adalah:

$$
\begin{gathered}
\text { BKA }=\mathrm{x}+\mathrm{k} . \sigma \\
\mathrm{BKB}=\mathrm{x}-\mathrm{k} . \sigma \\
\text { Sumber: Arif, } 2016
\end{gathered}
$$

Keterangan:

$$
\begin{array}{ll}
\mathrm{x} & =\text { Rata-rata waktun pengamatan } \\
\mathrm{k} & =\text { Konstanta tingkat kepercayaan 95\% } \\
\sigma & =\text { Standar deviasi }
\end{array}
$$

\subsection{Persentil}

Persentil merupakan suatu nilai yang menyatakan bahwa persentase tertentu dari sekelompok orang yang dimensinya sama dengan atau lebih rendah dari nilai tersebut. Misalnya 95\% dari populasi adalah sama atau lebih rendah dari 95 persentil, dan 5\% dari populasi berada sama dengan atau lebih rendah dari 5 persentil(Sokhibi 2017). Berikut merupakan perhitungan ukuran persentil: 
Tabel. 2.1 Distribusi Normal Dan Perhitungan Persentil

\begin{tabular}{|c|c|}
\hline Percentile & Perhitungan \\
\hline 1-st & $\mathrm{X}$ ? 2,325ㅁ? \\
\hline 2,5-th & X ?1,96? ? \\
\hline 5-th & $\mathrm{X}$ ? 1,645의? \\
\hline 10-th & X ?1,28?ㅁำ \\
\hline 50-th & $\overline{\mathrm{X}}$ \\
\hline 90-th & X ?1,28? ? \\
\hline 95-th & $\mathrm{X}$ ? 1,645回回 \\
\hline 97-th & X ?1,96? 回? \\
\hline 99-th & $\mathrm{X}$ 色 2,325의? \\
\hline
\end{tabular}

Sumber: Wignjosoebroto, 2006

\subsection{Data Anthropometri Yang Diperlukan Untuk Perancangan}

\section{Produk/Fasilitas Kerja}

Menurut wignjosoebroto (2006), data anthropometri yang menyajikan data ukuran dari berbagai macam anggota tubuh manusia dalam persentiler tertentu akan sangat besar manfaatnya pada saat suatu rancangan produk ataupun fasilitas kerja akan dibuat. Agar rancangan suatu produk nantinya bisa sesuai dengan ukuran tubuh manusia yang akan mengoperasikannya, maka prinsip prinsip apa yang harus ditetapan terlebih dahulu seperti berikut:

1. Prinsip perancangan produk bagi individu dengan ukuran yang ekstrim.

2. Prinsip perancangan produk yang bisa bisa dioperasikan diantara rentang ukuran tertentu.

3. Prinsip perancangan produk dengan ukuran rata - rata.

Data anthropometri yang di perlukan untuk perancangan produk/fasilitas kerja sebagai berikut: 


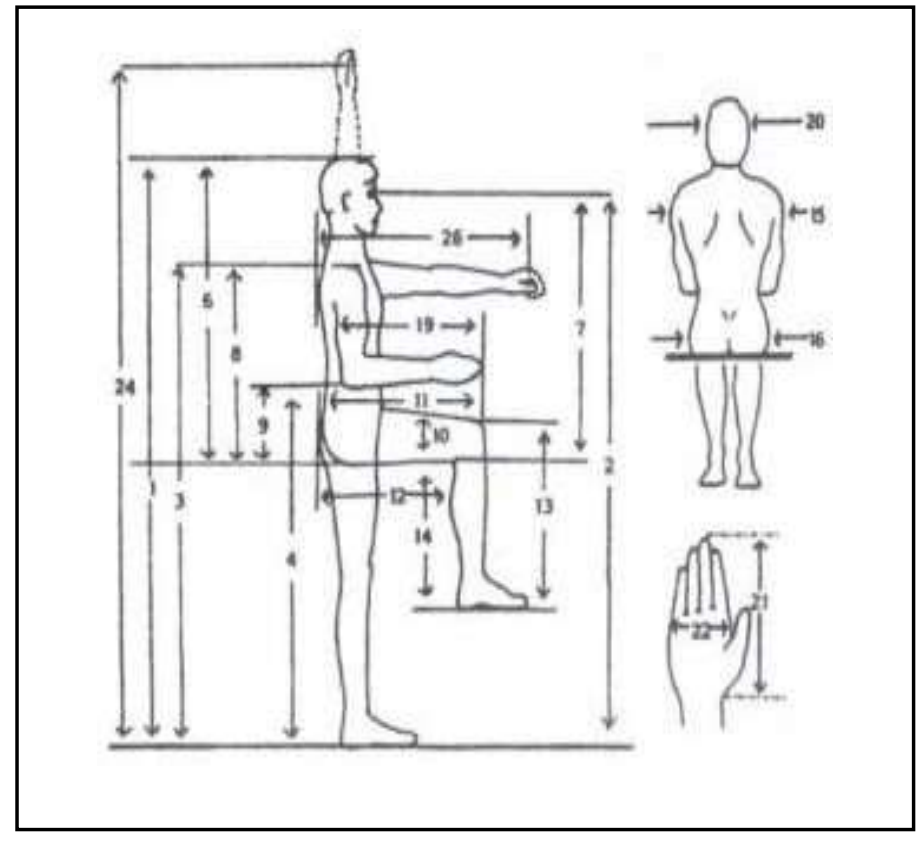

Gambar 2.1 Anthropometri Tubuh Manusia

Sumber: Sokhibi, 2017

1. Dimensi tinggi tubuh dalam posisi tegak.

2. Tinggi mata dalam posisi berdiri tegak.

3. Tinggi bahu dalam posisi berdiri tegak.

4. Tinggi siku dalam posisi tegak (siku tegak lurus).

5. Tinggi kepalan tangan yang terjulur lepas dalam posisi berdiri tegak

6. Tinggi tubuh dalam posisi duduk (diukur dari alas tempat duduk/pantat sampai dengan kepala). 
7. Tinggi kepala dalam posisi duduk.

8. Tinggi bahu dalam posisi duduk.

9. Tinggi siku dalam posisi duduk (siku tegak lurus).

10. Tebal atau lebar paha.

11. Panjang paha yang diukur dari pantat sampai dengan ujung lutut.

12. Panjang paha yang diukur dari pantat sampai dengan bagian belakang dari lutut/betis.

13. Tinggi lutut yang bisa diukur baik dalam posisi berdiri ataupun duduk.

14. Tinggi tubuh dalam posisi duduk yang diukur dari lantai sampai paha.

15. Lebar dari bahu (bisa diukur dalam posisi betrdiri ataupun duduk).

16. Lebar pinggul/pantat.

17. Lebar dari dada dalam keadaan membusung.

18. Lebar perut.

19. Panjang siku yang diukur dari siku sampai dengan ujung jari jari dalam posisi siku tegak lurus.

20. Lebar kepala.

21. Panjang tangan diukur dari pergelangan sampai dengan ujung jari.

22. Lebar telapak tangan. 
23. Lebar tangan dalam posisi tangan terbentang lebar - lebar kesamping kiri - kanan.

24. Tinggi jangkauan tangan dalam posisi berdiri tegak, diukur dari lantai samapai dengan telapak tangan yang terjangkau lurus keatas (vertikal).

25. Tinggi jangkauan tangan dalam posisi duduk tegak.

26. Jarak jangkauan tangan yang terlanjur kedepan diukur dari bahu sampai ujung jari tangan.

Soal

Hitunglah hasil pengukuran anthropometri data dibawah ini beserta presentil nya:

\begin{tabular}{|c|c|c|c|c|c|c|}
\hline \multirow{2}{*}{ No. } & \multirow{2}{*}{ Pengamatan } & \multicolumn{5}{|c|}{ Data (cm) } \\
\cline { 3 - 7 } & & TB & RB & RP & TL & PP \\
\hline 1. & Fadila (6) & 37 & 36 & 27 & 35 & 37 \\
\hline 2. & Zaki (6) & 33 & 30 & 26 & 32 & 33 \\
\hline 3. & Abidah (6) & 36 & 29 & 28 & 31 & 32 \\
\hline
\end{tabular}




\section{BAB. 8 \\ STUDI EKONOMI GERAKAN \\ (Micromotion Study)}

\subsection{Pengertian Studi Gerakan}

Menurut Lumbantobing (2018), studi gerakan adalah analisis yang dilakukan terhadap beberapa gerakan bagian tubuh pekerja dalam menyelesaikan pekerjaannya. Tujuan yang diperoleh dari penggunaan studi gerakan ini diharapkan agar gerakan-gerakan yang tidak perlu dapat dikurangi atau bahkan dihilangkan sehingga akan diperoleh penghematan baik dalam bentuk tenaga, waktu kerja maupun dana. Gerakan-gerakan yang dipelajari dapat dipermudah penganalisaanya dengan terlebih dahulu mengenali apa yang disebut sebagai gerakan-gerakan dasar sebagaimana yang dikembangkan secara mendalam oleh Frank B. Gilberth berserta istrinya, Lilian yang menguraikan gerakan ke dalam 11 gerakan dasar atau elemen gerakan yang mereka namakan therbligh's. Sebagian besar dari therbligh's - therbligh's ini merupakan gerakan-gerakan dasar dari tangan sehingga mudah dimengerti karena pada setiap pekerjaan produksi gerakan tangan merupakan gerakan yang paling umum dijumpai, terlebih lagi dalam pekerjaan yang bersifat manual. 


\subsection{Prinsip Ekonomi Gerakan}

Menurut Dewi (2015), prinsip dari ekonomi gerakan yaitu menganalisis dan mengevaluasi metode kerja guna memperoleh metode kerja yang lebih efisien.

Prinsip- prinsip yang diterapkan antara lain:

1. Gerakan hanya bagian badan yang diperlukan saja untuk melakukan pekerjaan dengan sebaik-baiknya,

2. Pekerjaan sebaiknya dirancang semudah-mudahnya dan jika memungkinkan irama kerja harus mengikuti irama yang alamiah bagi si pekerja.

3. Diusahakan agar bahan dan peralatan mempunyai tempat yang tetap.

4. Tempatkan bahan-bahan dan peralatan di tempat yang mudah, cepat, dan nyaman dicapai serta.

5. Keseimbangan beban tangan kiri dan tangan kanan.

Prinsip ekonomi gerakan menyatakan bahan dan peralatan tersebut ditempatkan sedemikian rupa sesuai dengan urutan terbaik dan ditempatkan di tempat yang mudah untuk dicapai atau masih berada dalam daerah kerja baik normal maupun maksimum.Dengan prinsip ekonomi gerakan dimana dengan menempatkan bahan dan peralatan ditempat yang tetap akan memudahkan pekerja untuk mengambilnya pada saat diperlukan. Jika tempat sudah tetap dan dikenali, tangan pekerja akan secara 
otomatis dapat mengambilnya sehingga aktivitas yang tidak diperlukan seperti mencari dapat dikurangi.

\subsection{Peta Tangan Kanan Tangan Kiri}

Menurut Kusumanto (2016), peta tangan kiri dan tangan kanan adalah peta kerja setempat yang bermanfaat untuk menganalisa gerakan tangan manusia di dalam melakukan pekerjaan-pekerjaan yang bersifat manual. Peta ini akan menggambarkan semua gerakan maupun delay yang terjadi yang dilakukan oleh tangan kanan maupun kiri secara mendetail dengan menganalisa detail gerakan yang terjadi maka langkah-langkah perbaikan bisa diusulkan.Pembuatan peta operator ini baru terasa bermanfaat apabila gerakan yang dianalisa tersebut terjadi berulang-ulang (repetitive) dan dilakukan secara manual.

\subsection{Gerakan Fundamental (Therbligh's)}

Menurut Herjanto (2007), therbligh's adalah elemen - elemen dasar dari gerakan, therbligh's dapat diibaratkan sebagai huruf huruf alphabet untuk gerakan. Huruf - huruf alphabet bila disusun secara tertentu dapat membentuk kata, dan rangkaian dari kata kata membentuk kalimat. Demikian pula therbligh's, rangkaian dari beberapa elemen therbligh's membentuk gerakan. Rangkaian dari gerakan membentuk tugas atau pekerjaan. Istilah therbligh's diambil dari nama penemunya, frank gilbreth, yang di eja terbalik dengan 
huruf $\mathrm{t}$ dan $\mathrm{h}$ bertukar posisi. Ide dasar analisa therbligh's ialah memecah gerakan dari elemen - elemen, kemudian memperbaiki gerakan melalui penghapusan, penggabungan, atau pengurutan elemen - elemen tersebut. Berikut beberapa simbol therbligs, menurut Wignjosoebroto (2006):

Tabel. 8.1 Macam - Macam Elemen Gerakan Therbligs.

\begin{tabular}{|c|c|c|c|}
\hline Nama Therbligs & $\begin{array}{l}\text { Lambang } \\
\text { Huruf }\end{array}$ & $\begin{array}{l}\text { Kode } \\
\text { Warna }\end{array}$ & $\begin{array}{l}\text { Lambang } \\
\text { Gambar }\end{array}$ \\
\hline Mencari (Search) & Sh & Black & \\
\hline Memilih (Select) & Si & Gray, Light & \\
\hline Memegang (Grasp) & G & Lake Red & \\
\hline $\begin{array}{l}\text { Menjangkau / Membawa } \\
\text { Tanpa Beban } \\
\text { (Transport Empty) }\end{array}$ & TE & Olive Green & \\
\hline $\begin{array}{l}\text { Membawa dengan Beban } \\
\text { (Transport Loaded) }\end{array}$ & TL & Green & \\
\hline Memegang ( Hold) & $\mathrm{H}$ & Gold Ochre & \\
\hline Melepas ( Release Laad) & RL & $\begin{array}{l}\text { Carmine } \\
\text { Red }\end{array}$ & \\
\hline Mengarahkan ( Position ) & $P$ & Blue & 9 \\
\hline $\begin{array}{l}\text { Mengarahkan Awal } \\
\text { (Pre Position) }\end{array}$ & PP & Sky Blue & \\
\hline Memeriksa ( Inspection) & 1 & Bum Ochre & 0 \\
\hline Merakit (Assemble) & A & $\begin{array}{l}\text { Violet, } \\
\text { Heavy }\end{array}$ & \\
\hline $\begin{array}{l}\text { Mengurai Rakit } \\
\text { (Disassemble) }\end{array}$ & DA & Violet & \\
\hline Memakai (Use) & $\mathrm{U}$ & Purple & C \\
\hline $\begin{array}{l}\text { Keterlambatan yang tak } \\
\text { terhindarkan } \\
\text { (Unavoidabel Delay) }\end{array}$ & UD & $\begin{array}{l}\text { Yellow } \\
\text { Ochre }\end{array}$ & \\
\hline $\begin{array}{l}\text { Keterlambatan yang dapat } \\
\text { dihindarkan } \\
\text { (Avoidable Delay) }\end{array}$ & AD & $\begin{array}{l}\text { Lemon } \\
\text { Yellow }\end{array}$ & مـ \\
\hline Merencana ( Plan) & $\mathrm{Pn}$ & Brown & $B$ \\
\hline $\begin{array}{l}\text { Istirahat untuk } \\
\text { menghilangkan lelah } \\
\text { (Rest to Overcome Fatigue) }\end{array}$ & $\mathbf{R}$ & Orange & R \\
\hline
\end{tabular}

Sumber: Wignjosoebroto, 2006 
Dari tabel 8.1 diatas, berikut definisi dari masing-masing gambar:

1. Mencari (search).

Elemen gerakan mencari merupakan gerakan dasar dari pekerja untuk menemukan lokasi objek. Pada gerakan ini yang bekerja adalah mata. Gerakan ini dimulai pada saat mata bergerak mencari objek dan berakhir bila objek sudah ditemukan. Tujuan dari analisa therblig ini adalah untuk menghilangkan sedapat mungkin gerak yang tidak perlu. Mencari merupakan gerak yang tidak efektif dan masih dapat dihindarkan misalnya dengan menyimpan peralatan atau bahan-bahan pada tempat yang tetap sehingga proses mencari dapat dihilangkan.

2. Memilih (select).

Memilih adalah elemen therbligs yang merupakan gerakan kerja menemukan/memilih suatu objek di antara dua atau lebih obyek yang sama lainnya. Elemen therbligs ini dimulai pada saat tangan dan mata mulai bergerak memilih dan berakhir bila objek yang dikehendaki sudah ditemukan. Elemen memilih biasanya mengikuti langsung elemen therbligs mencari (search). Batas antara memulai memilih dan akhir dari mencari agak sulit untuk ditentukan karena ada pembaharuan pakerjaan di antara dua gerakan tersebut yaitu gerakan yang dilakukan oleh mata.

3. Memegang (grasp).

Memegang adalah gerakan untuk memegang objek, biasanya didahului oleh gerakan menjangkau dan dilanjutkan oleh gerakan 
membawa. Memegang adalah termasuk elemen therbligs yang diklasifikasikan sebagai elemen gerakan efektif yang biasanya dapat dihilangkan akan tetapi dalam beberapa hal bisa diperbaiki.

4. Menjangkau/membawa tanpa beban (transport empty).

Menjangkau adalah elemen gerak therbligs yang menggambarkan gerakan tangan berpindah tempat tanpa beban atau hambatan (resistence) baik gerakan menuju atau menjauhi objek atau lokasi tujuan lainnya dan berakhir segera disaat tangan berhenti bergerak setelah mencapai objek tujuannya. Elemen gerakan ini biasanya didahului oleh gerakan melepas (release) dan diikuti oleh gerakan memegang (grasp). Waktu yang diperlukan untuk melaksanakan elemen gerak menjangkau akan sangat tergantung dengan jarak gerakan tangan yang dilakukan kearah objek yang dituju dan tipe gerakan menjangkaunya. Seperti halnya dengan elemen.

5. Membawa dengan beban (transport loaded).

Elemen gerakan membawa adalah juga merupakan gerak perpindahan tangan, hanya saja di sini tangan bergerak dalam kondisi membawa beban (objek). Elemen gerakan ini diawali dan diakhiri pada saat yang sama dengan elemen gerakan menjangkau (reach) hanya saja di sini tangan dalam kondisi membawa beban (objek). Faktor-faktor yang mempengaruhi waktu gerakannya pun hampir sama yaitu jarak perpindahan tangan, tipe gerakan dan berat ringan beban dibawa oleh tangan. 
6. Memegang untuk memakai (hold).

Pengertian memegang untuk memakai disini adalah memegang tanpa menggerakkan objek yang dipegang tersebut, perbedaannya dengan memegang yang terdahulu adalah pada perlakuan pada objek yang dipegang. Pada memegang, pemegangan dilanjutkan dengan gerak membawa, sedangkan memegang untuk memakai tidak demikian.

7. Melepas (release load).

Elemen gerak melepas terjadi pada saat tangan operator melepaskan objek yang dipegang sebelumnya. Dengan demikian elemen gerak ini diawali sesaat jari-jari tangan membuka lepas dan objek yang dibawa dan berakhir secara begitu semua jari jelas tidak menyentuh atau memegang objek lagi.

8. Mengarahkan (position).

Therbligs ini merupakan gerakan mengarahkan suatu objek pada suatu lokasi tertentu. Gerakan mengarahkan ini biasanya didahului oleh elemen gerakan (move) dan diikuti oleh gerakan merakit (assembling) atau melepas (release). Gerakan dimulai sejak tangan memegang/mengontrol objek tersebut kearah lokasi yang dituju dan berakhir pada saat gerakan berakhir atau melepas/memakai dimulai.

9. Mengarahkan awal (pre-position).

Elemen gerak mengarahkan awal adalah elemen kerja therbligs yang mengarahkan objek pada suatu tempat sementara sehingga 
pada saat kerja mengarahkan objek benar-benar dilakukan maka objek tersebut dengan mudah akan bisa dipegang dan dibawa kearah tujuan yang dikehendaki. Elemen therbligs ini sering terjadi bersamaan dengan therbligs yang diantaranya adalah membawa (move) dan melepaskan (release). Untuk mengurangi waktu kerja mengarahkan awal bisa dilakukan dengan merancang peralatan pembantu untuk memegang (holding device) perkakas kerja atau objek pada arah gerakan kerja yang semestinya. Berikut ini uraian perbedaan antara therbligs mengarahkan dengan therblig mengarahkan sementara.

10. Memeriksa (inspect).

Elemen therbligs ini termasuk cara kerja untuk menjamin bahwa objek telah memenuhi persyaratan kualitas yang ditetapkan. Gerakan kerja dilaksanakan dengan pengecekan secara rutin oleh operator selama proses kerja berlangsung. Elemen dapat berupa gerakan melihat seperti memeriksa warna, meraba seperti memeriksa kehalusan permukaan benda kerja dan lain-lain. Aktivitas yang prinsipnya memeriksa objek kerja untuk dibandingkan dengan standar yang ada. Waktu yang diperlukan untuk kegiatan memeriksa ini akan bergantung kepada kecepatan operator menemukan perbedaan antara objek dengan performansi standard yang dibandingkan. 


\section{Merakit (assemble).}

Perakitan adalah gerakan untuk menggabungkan satu objek dengan objek yang lain sehingga menjadi satu kesatuan. Gerakan ini biasanya didahului oleh salah satu therbligs membawa atau mengarahkan dan dilanjutkan oleh therbligs melepas. Pekerjaan perakitan dimulai bila objek sudah siap dipasang dan berakhir bila objek tersebut sudah tergabung secara sempurna.

12. Mengurai rakit (diassembly).

Elemen gerak ini merupakan kebalikan dari elemen therbligs merakit (assemble). Di sini dilakukan gerakan memisahkan atau menguraikan dua objek yang tergabung satu menjadi objek - objek terpisah. Gerakan mengurai rakit biasanya diawali oleh elemen memegang (grasp) dan dilanjutkan dengan membawa (move) atau melepas (release). Gerakan ini dimulai pada saat pemegangan atas objek telah selesai yang dilanjutkan dengan usaha memisahkan dan berakhir di saat objek telah terurai sempurna (biasanya terus diikuti dengan gerakan Therblig lainnya yaitu membawa atau melepas).

13. Memakai (use).

Memakai adalah elemen gerakan therbligs dimana salah satu atau kedua tangan digunakan untuk memakai/mengontrol suatu alat/objek untuk tujuan-tujuan tertentu selama kerja berlangsung. Lama waktu yang dipergunakan untukgerakan ini tergantung pada jenis pekerjaan atau kecakapan operator untuk menyelesaikan pekerjaan tersebut. 
14. Kelambatan yang tak terhindarkan (unavoidable delay).

Kelambatan yang dimaksudkan disini adalah kelambatan yang diakibatkan oleh hal-hal yang terjadi diluar kemampuan pengendalian pekerja. Hal ini timbul karena ketentuan cara kerja yang mengakibatkan satu tangan menganggur sedangkan tangan yang lainnya bekerja.

15. Kelambatan yang dapat dihindarkan (avoidable delay).

Setiap waktu menganggur (idle time) yang terjadi pada siklus kerja yang berlangsung merupakan tanggung jawab operator baik secara sengaja maupun tidak sengaja akan diklasifikasikan sebagai kelambatan yang bisa dihindarkan. Kegiatan ini menunjukkan situasi yang tidak produktif yang dilakukan oleh operator (merokok, mengobrol, mondar-mandir tanpa tujuan jelas, dan lain-lain) sehingga perbaikan/penanggulangan yang perlu dilakukan lebih ditujukan kepada operatornya sendiri tanpa harus mengubah proses operasi kerjanya.

16. Merencanakan (plan).

Merencana merupakan proses mental, dimana operator berpikir untuk menentukan tindakan yang akan diambil selanjutnya. Waktu untuk therbligs ini lebih sering terjadi pada seorang pekerja baru. Cara untuk memperbaiki adalah dengan jalan melatih atau training terhadap karyawan baru. 
17. Istirahat untuk menghilangkan lelah (rest to overcome fatigue). Elemen ini tidak terjadi pada setiap siklus kerja akan tetapi berlangsung secara periodik. Waktu untuk memulihkan kondisi badan dan kelelahan fisik akibat kerja berbeda-beda, tidak saja tergantung pada karakteristik pekerjaan yang ada tetapi juga tergantung individu pekerjanya. Untuk memperbaiki elemen-elemen therbligs yang diklasifikasikan sebagai nilai bisa dilaksanakan dengan memperhatikan faktor-faktor ergonomi yang secara signifikan berpengaruh besar terhadap performansi kerja manusia. 


\section{BAB. 9}

\section{LINGKUNGAN KERJA FISIK}

\subsection{Pengertian Lingkungan Kerja}

Menurut Prihantoro (2015), lingkungan kerja merupakan salah satu faktor yang dapat mempengaruhi produktivitas kerja dan efektivitas kerja pegawai. yang bentuknya dapat berupa lingkungan materil seperti tempat dan sarana produksi, serta lingkungan psikologis seperti suasana hubungan sosial antar personalperusahaan. pengertian lingkungan kerja adalah segala sesuatu yang ada di sekitar tenaga kerja dan dapat mempegaruhi dirinya dalam menjalankan tugas - tugas yang dibebankan kepadanya. Adapun indikatornya adalah hubungan antar karyawan, suasana kerja, dan fasilitas - fasilitas kerja karyawan.

\subsection{Jenis Lingkungan Kerja}

Lingkungan kerja adalah salah satu hal yang paling dekat dengan seseorang dalam pelaksanaan pekerjaannya. Lingkungan kerja terdiri dari lingkungan kerja fisik dan lingkungan kerja non fisik (Norianggono, 2014). 


\subsubsection{Lingkungan Kerja Fisik}

Menurut Norianggono (2014), pengertian dari lingkungan kerja fisik yaitu semua keadaan berbentuk fisik yang terdapat di sekitar tempat kerja dimana dapat mempengaruhi karyawan baik secara langsung maupun tidak langsung. Lingkungan kerja fisik sendiri dapat dibagi dalam dua kategori. Kategori yang pertama adalah lingkungan yang berhubungan langsung dengan karyawan dan berada di dekat karyawan(seperti meja, kursi dan sebagainya). Kategori yang kedua adalah lingkungan perantara atau lingkungan umum, dapat juga disebut lingkungan kerja yang mempengaruhi kondisi manusia, misalnya: temperatur, kelembaban, sirkulasi udara, pencahayaan, kebisingan, getaran mekanis, bau tidak sedap, warna, dan lain-lain.

\subsubsection{Lingkungan Kerja Non Fisik}

Lingkungan kerja nonfisik adalah semua keadaan yang terjadi yang berkaitan dengan hubungan kerja, baik hubungan dengan atasan maupun hubungan sesama rekan kerja, ataupun hubungan dengan bawahan.Dapat disimpulkan bahwa lingkungan kerja nonfisik adalah kondisi yang berkaitan dengan hubungan karyawan yang dapat mempengaruhi kinerja karyawan (Norianggono, 2014). 


\subsection{Faktor - Faktor Yang Mempengaruhi Lingkungan Kerja Fisik}

Dalam kehidupan sehari-hari untuk menjalankan aktivitas kerjanya, manusia dituntut untuk tetap dapat mempertahankan atau bahkan meningkatkan produktivitas kerjanya. Telah disinggung di atas bahwa produktivitas manusia dipengaruhi oleh faktor lingkungan kerja fisik dan non fisik. Secara harfiah, produktivitas manusia mayoritas dipengaruhi oleh lingkungan kerja fisik.Berikut ini adalah beberapa faktor - faktor yang mempengaruhi lingkungan kerja fisik manusia, yaitu:

\section{A. Suhu (suhu)}

Tubuh manusia selalu mempertahankan keadaan normal tubuhnya sehingga dapat menyesuaikan diri terhadap peruahan yang terjadi diluar tubuhnya. Kemampuan menyesuaikan terhadap suhu jika tidak melebihi 20\% kondisi panas dan 35\% kondisi dingin. Dalam keadaan normal tubuh manusia mempunyai suhu yang berbeda; mulut memiliki suhu sebesar $37^{\circ} \mathrm{C}$, dada memiliki suhu sebesar $35^{\circ} \mathrm{C}$ dan bagian kaki memiliki suhu sebesar $28^{\circ} \mathrm{C}$. Tubuh manusia akan menyesuaikan diri apabila kelebihan dan kekurangan panas.

Untuk kondisi optimal manusia dalam bekerja,suhu manusia yang baik berkisar antara $24^{\circ}-27^{\circ} \mathrm{C}$. Untuk negara dengan empat musin, rekomendasi untuk comfort zone pada musim dingin adalah suhu ideal berkisar antara $19-23{ }^{\circ} \mathrm{C}$ dan pada musim panas suhu ideal antara 22 - $24{ }^{\circ} \mathrm{C}$ (WHS, 1992; Grantham, 1992 dan Grandjean, 1993). 
Sedangkan untuk negara dengan dua musin seperti Indonesia, rekomendasi tersebut perlu mendapat koreksi. Sedangkan kaitannya dengan suhu panas lingkungan kerja, Grandjean (1993) memberikan batas toleransi suhu tinggi sebesar $35-40{ }^{\circ} \mathrm{C}$; kecepatan. Pengaruh tingkat suhu pada tubuh manusia saat bekerja berbedabeda seperti berikut:

1. $+49^{\circ} \mathrm{C}=$ Temperatur dapat ditahan sekitar 1 jam, tetapi jauh diatas tingkat kemampuan fisik dan mental.

2. $+30^{\circ} \mathrm{C}=$ Aktivitas mental dan daya tanggap mulai menurun dan cenderung untuk membuat kesalahan dalam pekerjaan, timbul kelelahan fisik.

3. $+24^{\circ} \mathrm{C}=$ Kondisi optimum.

4. $+10^{\circ} \mathrm{C}=$ Kelakuan fisik yang extreme mulai.

Penyakit atau gangguan yang dapat ditimbulkan karena pengaruh suhu tinggi yg terpapar ringan pada tubuh manusia antara lain:

a) Vasodilatasi, yaitu membesarnya pembuluh darah di dalam tubuh yang disebabkan sebagai respon tubuh terhadap kadar oksigen yang rendah (peningkatan suhu tubuh); sehingga oksigen dialirkan ke bagian tubuh yang paling membutuhkan.

b) Denyut jantung meningkat

c) Temparatur kulit meningkat 
d) Suhu inti tubuh pada awal nya turun kemudian meningkat dll.

Penyakit atau gangguan yg dapat ditimbulkan karena pengaruh suhu tinggi yang terpapar secara terus menerus dan dalam jangka waktu yang lama, antara lain:

a. Gangguan perilaku dan performansi kerja seperti, teriadinya kelelahan, sering melakukan istirahat curian dll.

b. Dehidrasi. Dehidrasi adalah suatu kehilangan cairan tubuh yang berlebihan yang disebabkan baik oleh penggantian cairan yang tidak cukup maupun karena gangguan kesehatan. Pada kehilangan cairan tubuh $<1,5$ gejalanya tidak nampak, kelelahan muncul lebih awal dan mulut mulai kering.

c. Heat Rash. 'Keadaan seperti biang keringat atau keringat buntat, gatal kulit akibat kondisi kulit terus basah. Pada kondisi demikian pekerja perlu beristirahat pada tempat yang lebih sejuk dan menggunakan bedak penghilang keringat.

d. Heat Cramps. Merupakan kejang-kejang otot tubuh (tangan dan kaki) akibat keluamya keringat yang menyebabkan hilangnya garam natrium dari tubuh yang kemungkinan besar disebabkan karena minum terlalu banyak dengan sedikit garam natrium. 
e. Heat Syncope atau Fainting. Keadaan ini disebabkan karena aliran darah ke otak tidak cukup karena sebagian besar aliran darah di bawa kepermukaan kulit atau perifer yang disebabkan karena pemaparan suhutmggi.

f. Heat Exhaustion. Keadaan ini terjadi apabila tubuh kehilangan terlalu banyak cairan dan atau kehilangan garam. Gejalanya mulut kering, sangat haus,kmah, dan sangat lelah. Gangguan ini biasanya banyak dtalami oleh pekerja yang belum beraklimatisasi terhadap suhu udara panas.

\section{B. Kelembaban Udara (humidity)}

Kelembaban udara adalah banyaknya air yang terkandung dalam udara (\%). Kelembaban udara dipengaruhi oleh suhu udara. Suhu udara yang tinggi maka kelembabannya sangat besar dan sebaliknya. Pengaruh terhadap manusia dalam bekerja adalah cepatnya denyut jantung dalam mengedarkan darah untuk memenuhi kebutuhan oksigen.

\section{Sirkulasi Udara (air flow)}

Udara disekitar kita mengandung 21\% oksigen, 78\% nitrogen, $0,03 \% \mathrm{CO}_{2}$ dan $0,97 \%$ gas lain yang merupakan campuran. Oksigen dibutuhkan untuk proses metabolisme. Udara yang bersih akan berpengaruh terhadap kesehatan manusia dalam bekerja sehingga 
diperlukan pengaturan udara (sirkulasi) dimana udara harus bebas lewat melalui ventilasi atau jendela. Untuk mengatasi udara yang kotor maka beberapa perkantoran menggunakan pendingin udara yang disebut AC (Air Conditioning).

Untuk negara dengan empat musim, rekomendasi sirkulasi udara yang disarankan untuk comfort zone pada musim dingin adalah kecepatan udara antara 0,1-0,2 m/det dan pada musim panas suhu ideal antara 0,15-0,4 m/det.

Sedangkan untuk negara dengan dua musim seperti Indonesia, kecepatan udara yang disarankan lebih kurang 0,2 m/det.

\section{Kebisingan}

Menurut Lubis (2015), untuk meningkatkan produktivitas kerja suara yang mengganggu perlu dikurangi. Bunyi bising dapat mengganggu konsentrasi dalam bekerja, untuk itu suara-suara ribut harus diusahakan berkurang. Turunnya konsentrasi karena ditimbulkan oleh suara bising dapat berdampak pada meningkatnya stres karyawan. Ada tiga aspek yang menentukan kualitas suara bunyi yang bisa menimbulkan tingkat gangguanterhadap manusia, yaitu:

1. Lama Bunyi

Lama waktu bunyi terdengar. Semakin lama telinga kitamendengar kebisinganmaka semakin buruk akibatnya bagipendengaran (tuli). 
2. Intensitas Kebisingan

Intensitas biasanya diukur dengan satuan desibel (dB), yangmenunjukan besarnya arus energi persatuan luas dan bataspendengaran manusia mencapai 70 desibel.

3. Frekuensi

Frekuensi suara menunjukan jumlah dari gelombanggelombangsuara yang sampai dengan telinga kita setiap detikyang dinyatakan dalam jumlah getaran perdetik atau $\mathrm{Hertz}(\mathrm{HZ})$.

Tabel 9.1 Nilai Ambang Batas (NAB) Kebisingan.

\begin{tabular}{|c|c|c|}
\hline No & Tingkat Kebisingan (dB) & Hamparan Harian \\
\hline 1. & 85 & 8 jam \\
\hline 2. & 88 & 4 jam \\
\hline 3. & 91 & 2 jam \\
\hline 4. & 94 & 1 jam \\
\hline 5. & 97 & 30 menit \\
\hline 6. & 100 & 15 menit \\
\hline
\end{tabular}

Sumber: Faritsy, 2017

Sumber kebisingan di perusahaan biasanya berasal dari mesinmesin untuk proses produksi dan alai-alat lain yang dipakai untuk melakukan pekerjaan. Contoh sumber-sumber kebisingan di perusahaan baik dari dalam maupun dari luar perusahaan seperti: 
- Generator, mesin diesel untuk pembangkit listrik

- Mesin-mesin produksi

- Mesin potong, gergaji, serut di perusahaan kayu

- Ketel uap atau boiler untuk pemanas air

- Alat-alat lain yang menimbulkan suara dan getaran seperti alat pertukangan

- Kendaraan bermotor dari lalulintas dll.

Sumber-sumber suara tersebut harus selalu diidentifikasi dan dinilai kehadirannya agar dapat dipantau sedini mungkin dalam upaya mencegah dan mengendalikan penganih pemaparan kebisingan terhadap pekerja yang terpapar. Dengan demikian penilaian tingkat intensitas kebisingan di perusahaan secara umum dimaksudkan untuk beberapa tujuan yaitu:

a) Memperoleh data intensitas kebisingan pada sumber suara

b) Memperoleh data intensitas kebisingan pada penerima suara (pekerja dan masyarakat sekitar perusahaan)

c) Menilai efektivitas sarana pengendalian kebisingan yang telah ada dan merencanakan langkah pengendalian lain yang lebih efektif.

d) Mengurangi tingkat intensitas kebisingan baik pada sumber suara maupun pada penerima suara sampai batas diperkenankan.

e) Membantu memilih alat pelindung dari kebisingan yang tepat sesuai jenis kebisingannya. 
NAB Kebisingan di tempat kerja berdasarkan Keputusan Menteri Tenaga Kerja No. Kep.51/MEN/1999 yang merupakan pembaharuan dari Surat Edaran Menteri Tenaga Kerja No. 01/MEN/ 1978 besarnya rata-rata adalah $85 \mathrm{~dB}(\mathrm{~A})$ untuk waktu kerja terus menerus tidak lebih dari 8 jam/ hari atau 40 jam seminggu. Besarnya NAB kebisingan yang ditetapkan tersebut sama dengan NAB untuk negara-negara lain seperti Australia (WHS, 1993), Amerika (ACGIH, 1991). Selanjutnya apabila tenaga kerja menerima pemaparan kebisingan lebih dari ketetapan tersebut, maka harus dilakukan pengurangan waktu pemaparan seperti pada tabel 3.1 di bawah. 
Tabel 9.1. Batas Waktu Pemaparan Kebisingan Per Hari KerjaBerdasarkan Intensitas Kebisingan Yang Diterima Pekerja

\begin{tabular}{|c|c|c|}
\hline \multicolumn{2}{|c|}{$\begin{array}{c}\text { Batas Waktu Pemaparan } \\
\text { Per Hari Kerja }\end{array}$} & \multirow{2}{*}{$\begin{array}{l}\text { Intensitas Kebisingan } \\
\text { Dalam dB(A) } \\
85\end{array}$} \\
\hline 8 & Jam & \\
\hline 4 & & 88 \\
\hline 2 & & 91 \\
\hline 1 & & 94 \\
\hline 30 & Menit & 97 \\
\hline 15 & & 100 \\
\hline 7,5 & & 103 \\
\hline 3,75 & & 106 \\
\hline 1,88 & & 109 \\
\hline 0,94 & & 112 \\
\hline 28,12 & Detik & 115 \\
\hline 14,06 & & 118 \\
\hline 7,03 & & 121 \\
\hline 3,52 & & 124 \\
\hline 1,76 & & 127 \\
\hline 0,88 & & 130 \\
\hline 0,44 & & 133 \\
\hline 0,22 & & 135 \\
\hline 0,11 & & 139 \\
\hline
\end{tabular}

Sumber: Kepmennaker No. 51 Tahun 1999.

Adapun penyakit atau gangguan yang muncul dengan adanya pengaruh kebisingan tersebut antara lain:

a) Stress menuju keadaan cepat marah, sakit kepala, dan gangguan tidur

b) Gangguan reaksi psikomotor

c) Kehilangan konsentrasi 
d) Gangguan komunikasi antara lawan bicara

e) Penurunan performansi kerja yang kesemuanya itu akan bermuara pada kehilangan efisiensi dan produktivkas kerja.

Adapun sumber bunyi kebisingan yang disesuaikan dengan kekuatan kebisingan (decibel) seperti yang telah dijelaskan di atas, dapat dilihat pada tabel di bawah ini:

\begin{tabular}{|l|c|l|}
\hline \multicolumn{1}{|c|}{ Kondisi } & $\begin{array}{c}\text { Desibel } \\
\text { (dB) }\end{array}$ & \multicolumn{1}{|c|}{ Batas Dengar Tertinggi } \\
\hline Menuliskan & 120 & Halilintar \\
110 & Meriam \\
100 & Mesin uap \\
\hline Sangat hiruk pikuk & 90 & Jalan hiruk pikuk \\
& 80 & Perusahaan sangat gaduh \\
& & Pluit polisi \\
\hline Kuat & 70 & Rumah gaduh \\
& 60 & Jalan pada umumnya \\
& 50 & Perusahaan \\
\hline Sedang & 40 & Rumah gaduh \\
& & Rercakapan kuat \\
& 30 & Radio peralatan \\
\hline Tenang & 20 & Rumah tenang \\
& & Kantor pribadi \\
& & Auditorium \\
& Percakapan \\
\hline
\end{tabular}




\section{Pencahayaan}

Menurut Faritsy (2017), pencahayaan yang kurang dapat menyebabkan mata operator kerja cepat lelah, sehingga bisa menimbulkan kesalahan kerja. Pencahayaan sangat mempengaruhi manusia untuk melihat obyek - obyek secara jelas, cepat tanpa menimbulkan kesalahan. Kemampuan mata untuk melihat obyek dengan jelas ditentukan oleh ukuran obyek derajat kontras antara obyek dengan sekelilingnya, luminasi (brightness), serta lamanya waktu untuk melihat obyek tersebut berdasarkan jenis kegiatannya disajikan pada table berikut:

Table 9.2 Nilai Ambang Batas (NAB) Pencahayaan.

\begin{tabular}{|l|c|l|}
\hline \multicolumn{1}{|c|}{ Jenis kegiatan } & $\begin{array}{c}\text { Tingkat Pencahayaan } \\
\text { Minimal (Lux) }\end{array}$ & \multicolumn{1}{c|}{ Keterangan } \\
\hline $\begin{array}{l}\text { Penerangan } \\
\text { sekeliling }\end{array}$ & 20 & $\begin{array}{l}\text { Penerangan lingkungan } \\
\text { disekitar perusahaan } \\
\text { yang meliputi jalan dan } \\
\text { halaman perusahaan }\end{array}$ \\
\hline $\begin{array}{l}\text { Pekerjaan kasar } \\
\text { dan tidak terus- } \\
\text { menerus }\end{array}$ & $50-100$ & $\begin{array}{l}\text { Ruang penyimpanan dan } \\
\text { peralatan atau instalasi } \\
\text { yang memerlukan } \\
\text { pekerjaan kontinyu. }\end{array}$ \\
\hline $\begin{array}{l}\text { Pekerjaan yang } \\
\text { membedakan } \\
\text { barang-barang } \\
\text { kecil secara } \\
\text { sepintas }\end{array}$ & 100 & $\begin{array}{l}\text { Penerangan yang cukup } \\
\text { untuk pekerjaan yang } \\
\text { membedakan barang- } \\
\text { barang kecil secara } \\
\text { sepintas }\end{array}$ \\
\hline $\begin{array}{l}\text { Pekerjaan kasar } \\
\text { dan terusmenerus }\end{array}$ & 200 & $\begin{array}{l}\text { Pekerjaan dengan mesin } \\
\text { dan perakitan kasar. }\end{array}$ \\
\hline
\end{tabular}




\begin{tabular}{|l|c|l|}
\hline Pekerjaan rutin & 300 & $\begin{array}{l}\text { Ruang administrasi, ruang } \\
\text { kontrol, pekerjaan mesin } \\
\text { dan perakitan. }\end{array}$ \\
\hline $\begin{array}{l}\text { Pekerjaan agak } \\
\text { halus }\end{array}$ & 500 & $\begin{array}{l}\text { Pembuatan gambar atau } \\
\text { bekerja dengan mesin } \\
\text { kantor, pemeriksaan atau } \\
\text { pekerjaan dengan mesin }\end{array}$ \\
\hline Pekerjaan halus & 1000 & $\begin{array}{l}\text { Pemilihan warna, } \\
\text { pemrosesan tekstil, } \\
\text { pekerjaan mesin halus dan } \\
\text { perakitan halus }\end{array}$ \\
\hline $\begin{array}{l}\text { Pekerjaan sangat } \\
\text { halus }\end{array}$ & 1500 & $\begin{array}{l}\text { (tidak menimbulkan } \\
\text { bayangan) Mengukir } \\
\text { dengan tangan, } \\
\text { pemeriksaan pekerjaan } \\
\text { mesin, dan perakitan yang } \\
\text { sangat halus }\end{array}$ \\
\hline Pekerjaan terinci & 3000 & $\begin{array}{l}\text { (tidakmenimbulkan } \\
\text { bayangan) Pemeriksaan } \\
\text { pekerjaan, perakitan } \\
\text { sangat halus }\end{array}$ \\
\hline
\end{tabular}

Sumber: Faritsy, 2017

Intensitas penerangan yang dibutuhkan di masing-masing tempat kerja ditemukan dari jenis dan sifat pekerjaan yang dilakukan. Semakin tinggi tingkat ketelitian suatu pekerjaan, maka akan semakin besar kebutuhan intensitas penerangan yang diperlukan, demikian pula sebaliknya. Standar penerangan di Indonesia telah ditetapkan seperti tersebut dalam Peraturan Menteri Perburuhan (PMP) No. 7 Tahun 1964, Tentang syarat-syarat kesehatan, kebersihan dan penerangan di tempat keija. Standar penerangan yang ditetapkan 
untuk di indonesia tersebut secara garis besar hampir sama dengan standar internasional.

\subsection{Regresi Linier}

Menurut Purnomo (2017), regresi linier adalah analisis untuk mengetahui pengaruh atau hubungan secara linear antara variabel independen terhadap variabel dependen dan untuk memprediksi atau meramalkan suatu nilai variabel dependen berdasarkan variabel independen. Analisis regresi linier sederhana yaitu menganalisis hubungan linier antara 1 variabel independen dengan satu variabel dependen. Rumus persamaan umum garis regresi untuk regresi linier sederhana:

$$
\mathrm{Y}=\mathrm{K}+\mathrm{AX} 1+\mathrm{AX} 2+\mathrm{AX} 3
$$

Sumber: Harinaldi, 2005

Keterangan :

$Y=$ Nilai Regresi

$\mathrm{K}=$ Konstanta

$A=$ Variabel bebas

Berikut adalah analisis uji regresi linier dari hasil praktikum perancangan sistem kerja dan ergonomi modul lingkungan kerja fisik menggunakan software SPSS, dibawah ini adalah langkah-langkah kerjanya yaitu:

1. Buka aplikasi atau klik iconSPSS, seperti pada gambar 4.1. 


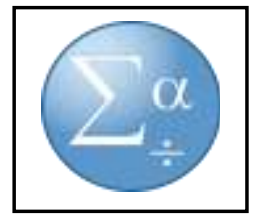

Gambar 4.1 Icon SPSS 22.0.

2. Klik variable view dan masukkan variable performansi, $\mathrm{x} 1, \mathrm{x} 2$, x3, kemudian pada tabel label masukkan variable suhu $x 1$, pencahayaan pada $\times 2$, dan kebisingan pada $\times 3$.

\begin{tabular}{|c|c|c|c|c|c|c|c|c|c|c|c|}
\hline \multicolumn{12}{|c|}{ 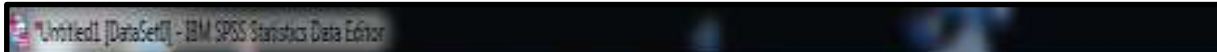 } \\
\hline \multicolumn{12}{|c|}{ 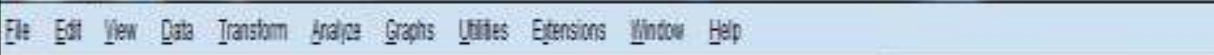 } \\
\hline \multicolumn{12}{|c|}{ 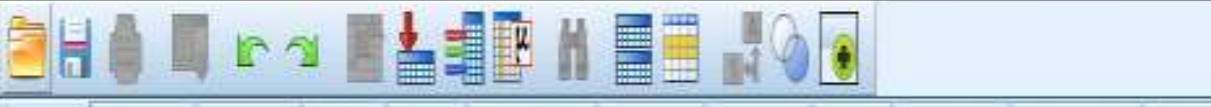 } \\
\hline & Nlane & Type & Vidh & Decinals & Labal & Valies & Ussing & Cotims & Alg & Mesure & Rate \\
\hline 1 & patumanil & liunaic & 8 & 2 & & Nine & Hose & 8 & 咅Pught & Scala & S loput. \\
\hline 2 & xi & liunaic & 8 & $\theta$ & sưu & Mine & Nhre & 8 & 害P Pugtt & A Scala & Vinpt \\
\hline 3 & 12 & Plunaic & 8 & 0 & pencahajazin & Alne & Nare & 8 & 㪯Fiygt & A Scal: & Ylopt. \\
\hline 4 & X & Nuneac & 8 & 0 & keaisingan & None & Nare & 8 & 害Piggt & 8 Scala & I lipost. \\
\hline \multicolumn{12}{|l|}{5.} \\
\hline \multicolumn{12}{|l|}{ ह } \\
\hline 7 & & & & & & & & & & & \\
\hline
\end{tabular}

3. Kemudian masukkan nilai pengamatan pada data view, seperti terlihat pada gambar 4.3. 


\begin{tabular}{|c|c|c|c|c|c|}
\hline & $\$$ performansi & $8 \times 1$ & $\& \times 2$ & $8 \times 3$ & var \\
\hline 1 & 5,76 & 30 & 50 & 60 & \\
\hline 2 & 5,63 & 30 & 50 & 80 & \\
\hline 3 & 4,43 & 30 & 50 & 100 & \\
\hline 4 & 1,08 & 30 & 125 & 60 & \\
\hline 5 & 83 & 30 & 125 & 80 & \\
\hline 6 & 91 & 30 & 125 & 100 & \\
\hline 7 & ,78 & 30 & 200 & 60 & \\
\hline 8 & .93 & 30 & 200 & 80 & \\
\hline 9 & 90 & 30 & 200 & 100 & \\
\hline 10 & 2,57 & 23 & 50 & 60 & \\
\hline 11 & 2,17 & 23 & 50 & 80 & \\
\hline 12 & 1,62 & 23 & 50 & 100 & \\
\hline 13 & 1,13 & 23 & 125 & 60 & \\
\hline 14 & 1,00 & 23 & 125 & 80 & \\
\hline 15 & 1,05 & 23 & 125 & 100 & \\
\hline 16 & 97 & 23 & 200 & 60 & \\
\hline 17 & 92 & 23 & 200 & 80 & \\
\hline 18 & 90 & 23 & 200 & 100 & \\
\hline 19 & 1,58 & 16 & 50 & 60 & \\
\hline 20 & 1,25 & 16 & 50 & 80 & \\
\hline 21 & 1,40 & 16 & 50 & 100 & \\
\hline 22 & 95 & 16 & 125 & 60 & \\
\hline 23 & 1,07 & 16 & 125 & 80 & \\
\hline 24 & 1,03 & 16 & 125 & 100 & \\
\hline 25 & 90 & 16 & 200 & 60 & \\
\hline 26 &, 88 & 16 & 200 & 80 & \\
\hline 27 &, 87 & 16 & 200 & 100 & \\
\hline
\end{tabular}

Gambar 4.3 Input Data View. 
4. Klik menu analyze, lalu klik regression kemudian klik linear.

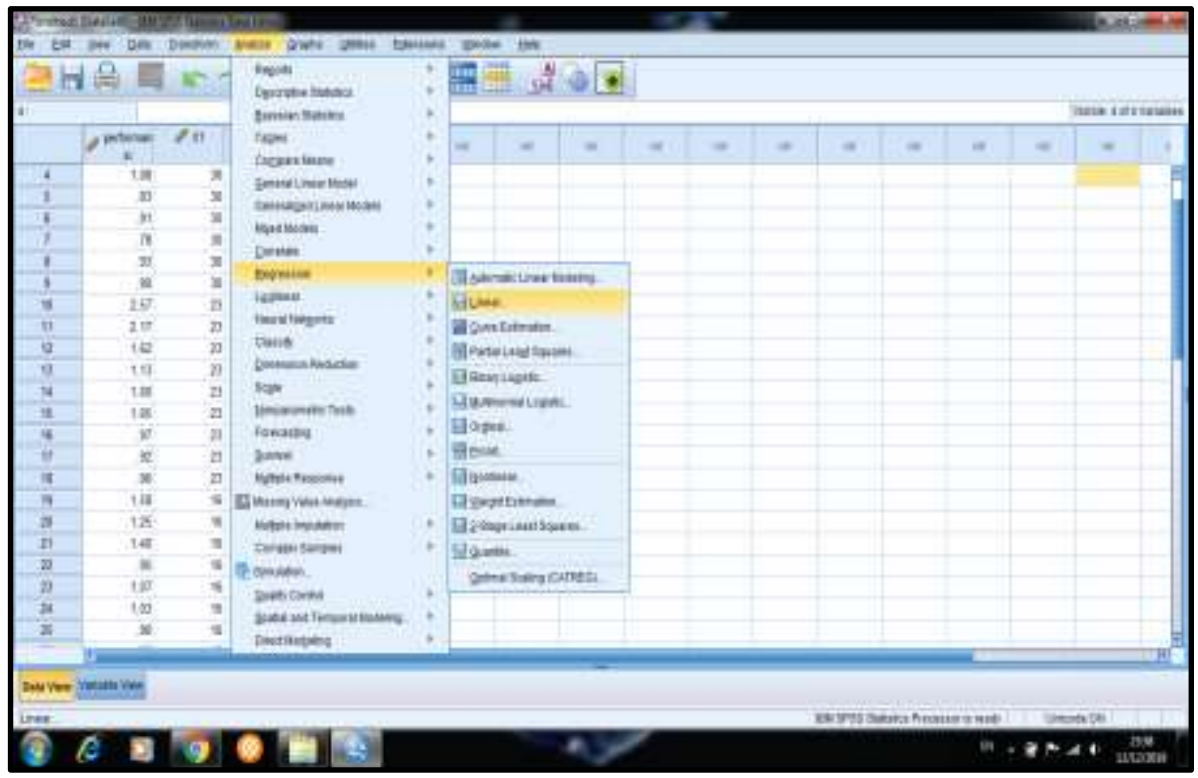

Gambar 4.4 Memilih Menu Analyze, Regression dan Linear.

5. Akan muncul tampilan kotak dialog linear regression, seperti pada gambar berikut. 
performansi

suhu [X1]

pencahayaan [X2]

kebisingan [X3]

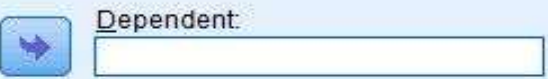

Block 1 of 1

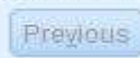

Next

Independent(s):

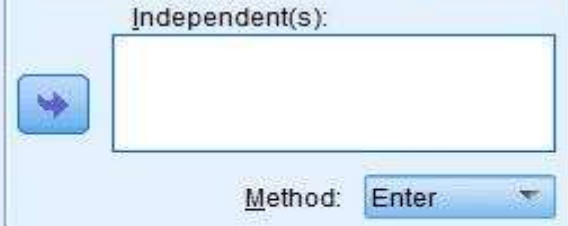

Method: Enter

Selection Variable:

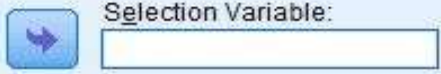

Rule

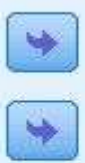

Case Labels:

WLS Weight:

Gambar 4.5 Dialog Linear Regression.

6. Kemudian masukkan performansi ke dalam daftar dependent lalu masukkan suhu, pencahayaan dan kebisingan pada daftar independent, kemudian klik ok, seperti pada gambar 4.6. 
suhu $[X 1]$

pencahayaan [X2]

kebisingan [X3]

\section{Dependent

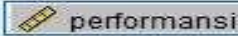

Block 1 of 1

Previous

Independent(s):

suhu [X1]

pencahayaan [X2]

kebisingan [X3]

Method: Enter

Next

Statistics

Plots

Sạve

Opptions

Style

Boootstrap

Gambar 4.6 Memasukkan Variabel Dependent dan Independent

7. Kemudian klik statistics sebelah kanan pilih estimates, mode it, dan descriptives padaregression coefficient, lalu klik continue, seperti pada gambar 4.7. 


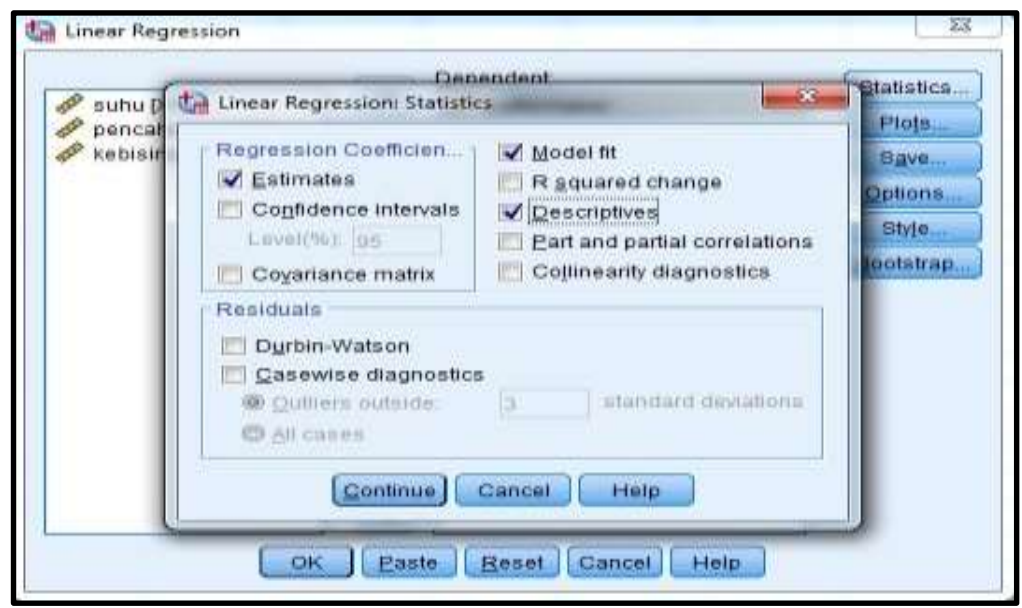

Gambar 4.7 MenuDari Statistics.

8. Klik plots kemudian masukkan Dependent pada tabel $\mathrm{Y}$, dan Adjpred pada tabel X lalu klik continue.

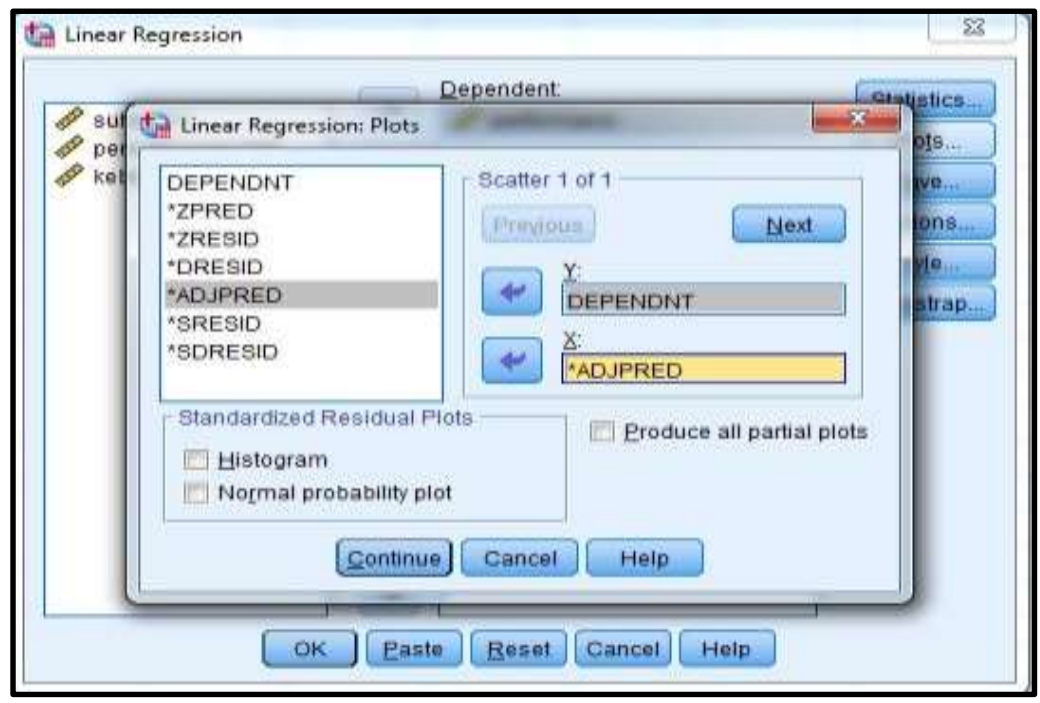

Gambar 4.8 Menu dari Plots. 
9. Kemudian klik save dan klik unstandardized pada tabel predicted value lalu klik continue.

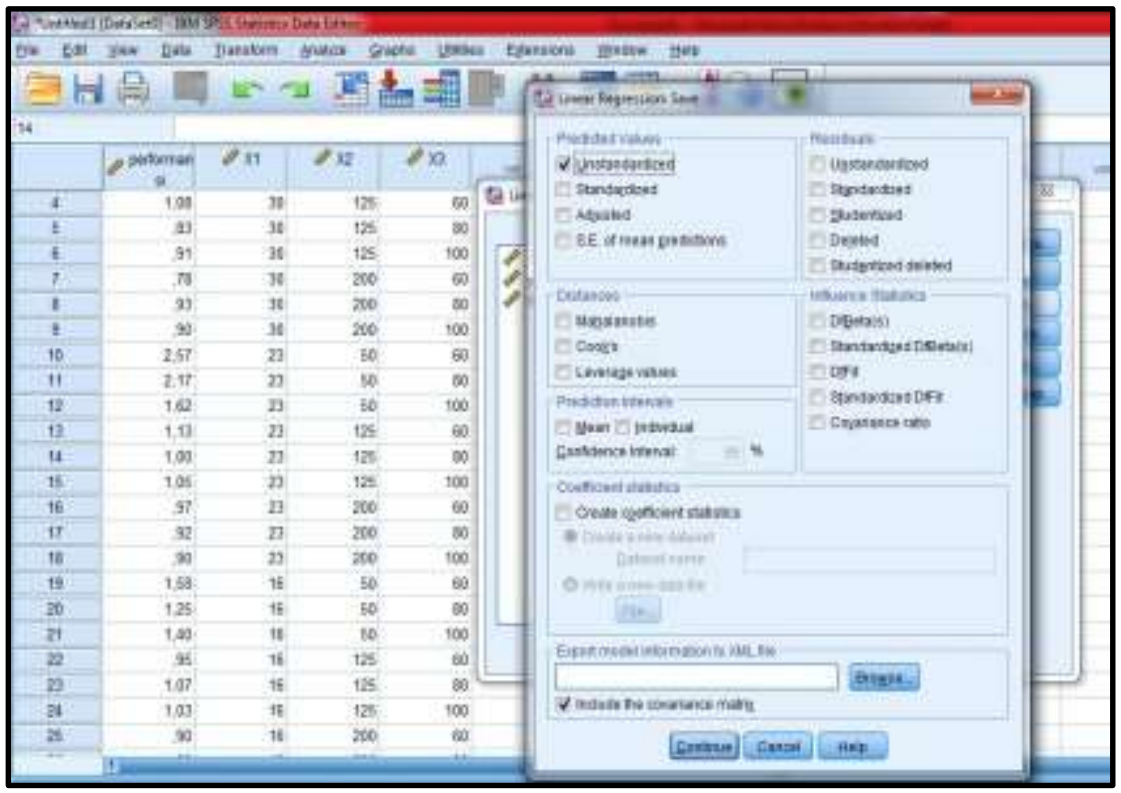

Gambar 4.9 MenuDari Save.

10. Klik options masukkan entry 0,05 dan removal 0,10 pada stepping method i lalu klik continue, seperti pada gambar 4.10. 


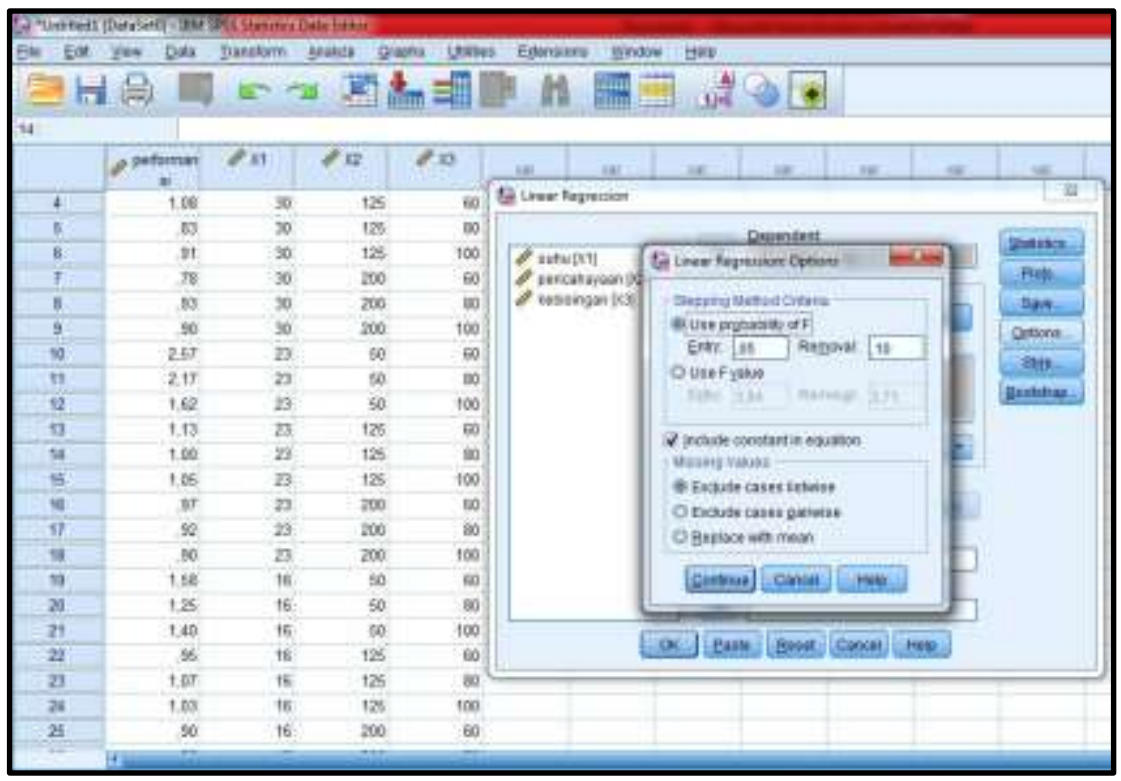

Gambar 4.10 MenuDari Options.

11. Maka akan keluar secara otomatis data yang telah kita input menjadi suatu analisa hasil uji normalitas dengan menggunakan software SPSS.

\begin{tabular}{|c|c|c|c|c|c|c|}
\hline \multicolumn{7}{|c|}{ Coefficients $^{a}$} \\
\hline \multirow[b]{2}{*}{ Model } & & \multicolumn{2}{|c|}{ Unstandardized Coefficients } & \multirow{2}{*}{$\begin{array}{c}\text { Standardized } \\
\text { Coefficients } \\
\text { Beta }\end{array}$} & \multirow[b]{2}{*}{$\mathrm{t}$} & \multirow[b]{2}{*}{ Sig. } \\
\hline & & B & Std. Error & & & \\
\hline 1 & (Constant) & 1,825 & 1,338 & & 1,364 & .186 \\
\hline & suhu &, 090 &, 035 &, 375 & 2,585 & 017 \\
\hline & pencahayaan &,- 014 &, 003 &,- 608 & $-4,192$ &, 000 \\
\hline & kebisingan &,- 007 &, 012 &,- 086 &,- 596 &, 557 \\
\hline
\end{tabular}

Gambar 4.11 Output Coefficients Data. 


\subsection{Hasil Uji Linier Regression Dengan Software SPSS}

Berikut ini adalah hasil dari uji linier regression dengan menggunakan software SPSS yang didapatkan sebagai berikut.

\begin{tabular}{|c|c|c|c|c|c|c|}
\hline \multicolumn{7}{|c|}{ Coefficients $^{a}$} \\
\hline \multirow[b]{2}{*}{ Model } & & \multicolumn{2}{|c|}{ Unstandardized Coefficients } & \multirow{2}{*}{$\begin{array}{c}\text { Standardized } \\
\text { Coefficients } \\
\text { Beta }\end{array}$} & \multirow[b]{2}{*}{$t$} & \multirow[b]{2}{*}{ Sig. } \\
\hline & & B & Std. Error & & & \\
\hline \multirow[t]{4}{*}{1} & (Constant) & 1,825 & 1,338 & & 1,364 & .186 \\
\hline & suhu &, 090 &, 035 &, 375 & 2,585 &, 017 \\
\hline & pencahayaan & -.014 &, 003 &,- 608 & $-4,192$ &, 000 \\
\hline & kebisingan &,- 007 &, 012 &,- 086 &,- 596 &, 557 \\
\hline
\end{tabular}

Gambar 4.12 Hasil Coefficients Pada Uji Linier Regression

Dari gambar 4.12 diatas diperoleh nilai sebagai berikut :

1. Nilai B pada performansi adalah 1.825 , karena dalam gambar terdapat nilai konstanta yang berati nilai tersebut tetap.

2. Nilai A pada suhu adalah 0,090 , disini bernilai plus(+) adalah kemungkinan waktu produksi bisa bertambah.

3. Nilai A pada pencahayaan adalah $-0,014$, disini bernilai minus(-) adalah kemungkinan waktu produksi bisa berkurang.

4. Nilai $A$ pada kebisingan adalah $-0,007$, disini bernilai minus(-) adalah kemungkinan waktu produksi bisa berkurang. 


\section{BAB. 10}

\section{BIOMEKANIKA}

\subsection{Pengertian Biomekanika}

Menurut Irzal (2016), biomekanika merupakan ilmu yang menggunakan hukum-hukum fisika dan konsep konsep mekanika untuk mendeskripsikan gerakan dan gaya pada berbagai macam bagian tubuh ketika melakukan aktivitas.

Biomekanika didefinisikan sebagai bidang ilmu aplikasi mekanika pada sistem biologi.Biomekanika merupakan kombinasi antara disiplin ilmu mekanika terapan dan ilmu-ilmu biologi dan fisiologi.Biomekanika menyangkut tubuh manusia dan hampir semua tubuh mahluk hidup. Dalam praktiknya biomekanika mempelajari kekuatan, ketahanan, dan ketelitian manusia dalam melakukan kerjanya.Biomekanika juga mengkaji hubungan pekerja dengan perlengkapan kerjanya, lingkungan kerja dan sebagainya (Soleman, 2011).

Biomekanika merupakan studi tentang karakteristik karakteristik tubuh manusia dalam istilah mekanik. Biomekanika dioperasikan pada tubuh manusia baik saat tubuh dalam keadaan statis ataupun dalam keadaan dinamis 
Biomekanika menggunakan hukum-hukum mengenai konsep fisik dan teknik untukmenggambarkan gerakan yang dialami oleh bagian-bagian tubuh yang beragam dan aksi gaya pada bagian bagian tubuh tersebut selama melakukan aktivitas harian normal. Dilihat dari defenisi tersebut, biomekanika adalah aktifitas multi disipliner (Soleman, 2011). Adapun faktor-faktor yang mempengaruhi biomekanika yaitu :

1) Umur, Jenis kelamin, suku bangsa.

2) Sikap kerja.

3) Jenis kerja.

\subsection{Sistem kardiovaskular}

Peningkatan intensitas kerja fisik menentukan kebutuhan akan tambahan energi yang dapat berlangsung melalui peningkatan konsumsi oksigen. Untuk memenuhi hal ini, frekuensi kontraksi jantung akan bertambah, sabagaimana terukur dari kenaikan denyut jantung. Kenaikan konsumsi oksigen dan jantung cenderung bersifat linear, khususnya untuk beban kerja yang tidak terlalu rintang ataupun terlalu berat. Untuk pekerjaan dengan beban yang sama, denyut jantung cenderung akan lebih rendah apabila pekerjaan tersebut dikerjakan dengan memanfaatkan otot-otot yang lebih besar. Hubungan antara konsumsi oksigen dan denyut jantung juga dipengaruhi oleh temperatur lingkungan kerja. Denyut jantung akan 
lebih tinggi saat pekerjaan dilakukan di tempat panas (Iridiastadi, 2014).

Peningkatan denyut jantung terjadi tidak hanya karena adanya kenaikan bebam kerja, tetapi juga dapat disebabkan oleh adanya komponen kerja statis (kontraksi isometris). Kerja otot yang relatif statis (dengan kontraksi di atas $20 \%$ kontraksi maksimal) menyebkan tertekannya pembuluh darah kapiler, sehingga dalam beberapa saat aja, aliran darah menjadi sangat terbatas (ischemia) atau bahkan tertutup sama sekali. Hal ini akan berdampak pada minimnya ketersedianan oksigen serta penumpukan sisa metabolism pada otot yang tengah bekerja. Akibatnya, rasa sakit akan muncul dan kontraksi otot terpaksa harus berakhir. Fenomena seperti ini dapat diamati, misalnya saat seseorang secara terus-menerus memegang peralatan kerja dengan posisi lengan di atas ketinggian dada (iridiastadi, 2014).

Peningkatan yang potensial dalam denyut nadi dari istirahat sampai kerja maksimum oleh Rodahl (1989) dalam Widodo, S (2008) didefinisikan sebagai Heart Rate Reverse (HR Reverse) yang diekspresikan dalam presentase.

Menurut Purbasari (2019), penilaian klasifikasi tingkatan beban kerja tidak langsung dapat ditentukan dari prosentase beban kardiovaskular (\%CVL). Nilai \%CVL dihitung dari tingkatan klasifikasi beban kerja berdasarkan peningkatan denyut nadi kerja yangdibandingkan dengan denyut nadi maksimum, dengan rumus sebagai berikut: 


$$
\% C V L=\left(\frac{\text { Denyut Nadi Kerja-Denyut Nadi Istirahat }}{\text { Denyut Nadi Maksimum-Denyut Nadi Istirahat }}\right) \times 100 \%
$$

Sumber: Purbasari, 2019

Di mana perhitungan denyut nadi maksimum adalah sebagai berikut:

$$
\begin{aligned}
& \hline \text { Laki-laki }=220-\text { umur } \\
& \text { Wanita }=200-\text { umur }
\end{aligned}
$$

Sumber: Purbasari, 2019

Klasifikasi beban kerja berdasarkan \%CVL telah ditetapkan sebagai berikut:

Tabel 2.3 Klasifikasi Beban Kerja Berdasarkan \%CVL

\begin{tabular}{|c|c|}
\hline Rentang & Klasifikasi \\
\hline$<30 \%$ & Tidak terjadi kelelahan \\
\hline $30 \%$ s.d $<60 \%$ & Diperlukan Perbaikan \\
\hline $60 \%$ s.d $<80 \%$ & Kerja dalam waktu singkat \\
\hline $80 \%$ s.d $<100 \%$ & Diperlukan tindakan segera \\
\hline$>100 \%$ & Tidak diperbolehkan beraktivitas \\
\hline
\end{tabular}

\subsection{Pengukuran Fisiologis}

Proses pengukuran fisiologis merupakan sebuah cara atau metode untuk menghitung kebutuhan waktu istirahat, cardiovascular load, serta hubungan denyut jantung dengan energi expenditure dari sebuah aktivitas yang dilakukan manusia. Energi expenditure dapat diartikan sebagai pengeluaran energy total individu yang berasal dari 
tiga komponen, yaitu metabolisme basal (penggunaan energy pada saat istirahat), efek konsumsi makanan dan aktivitas fisik.

10.3.1. Kebutuhan Waktu Istirahat

Kebutuhan waktu istirahat dapat dicari dengan rumus sebagai berikut:

$R=\frac{\mathrm{T}(\mathrm{W}-\mathrm{S})}{\mathrm{W}-1.5}$

Dimana:

$\mathrm{R}=$ Istirahat yang dibutuhkan dalam menit (recovery)

$\mathrm{T}$ = Total waktu kerja dalam menit

$\mathrm{W}=$ Konsumsi energi rata-rata untuk bekerja dalam kkal/menit

$S=$ Pengeluaran energi rata-rata yang direkomendasikan dalam $\mathrm{kkal} /$ menit (biasanya 4 atau $5 \mathrm{kkal} /$ menit)

a. Percobaan Pertama

Diketahui:

$\mathrm{T}=3$ menit 47 detik $=3,78$ menit

$\mathrm{S}=29 \mathrm{kal} / \mathrm{menit}$

Ditanya: R ?

Jawab:

$W=\frac{\mathrm{S}}{\mathrm{T}}$

$W=\frac{29}{3,78}$

$W=7,67$ menit 
Maka

$$
\begin{aligned}
& R=\frac{\mathrm{T}(\mathrm{W}-\mathrm{S})}{\mathrm{W}-1.5} \\
& R=\frac{3,78(7,67-4)}{7,67-1.5} \\
& R=\frac{3,78 \cdot(3,67)}{6,17} \\
& R=\frac{13,87}{6,17} \\
& R=2,25 \text { Menit }
\end{aligned}
$$

b. Percobaan Kedua

Diketahui:

$\mathrm{T}=4$ menit 14 detik $=4,23$ menit

$\mathrm{S}=48 \mathrm{kal} / \mathrm{menit}$

Ditanya: $R$ ?

Jawab:

$$
\begin{aligned}
& W=\frac{\mathrm{S}}{\mathrm{T}} \\
& W=\frac{48}{4,23} \\
& W=11,35 \text { menit }
\end{aligned}
$$

Maka

$$
\begin{aligned}
& R=\frac{\mathrm{T}(\mathrm{W}-\mathrm{S})}{\mathrm{W}-1.5} \\
& R=\frac{4,23(11,35-4)}{11,35-1.5}
\end{aligned}
$$




$$
\begin{aligned}
& R=\frac{4,23 \cdot(7,35)}{9,85} \\
& R=\frac{31,09}{9,85} \\
& R=3,16 \text { Menit }
\end{aligned}
$$

\subsubsection{Metode Cardiovascular Load.}

Metode Cardiovascular Load merupakan metode analisa beban kerja fisik, yang membandingkan denyut nadi maksimal dengan denyut nadi kerja. Adapun rumus perhitungan cardiovascularload dapat dicari dengan rumus sebagai berikut:

$C V L=\frac{(\text { Denyut nadi kerja }- \text { Denyut nadi istirahat) } \times 100 \%}{\text { Denyut nadi maksimum }- \text { Denyut nadi istirahat }}$

a. Percobaan pertama

Diketahui:

Denyut nadi kerja $=121$

Denyut nadi istirahat $=76$

Denyut nadi maksimum $=140$

Ditanya: CVL (cardiovascular) ?

Jawab:

$$
\begin{aligned}
C V L & =\frac{(121-76) \times 100 \%}{140-76} \\
& =\frac{(45) \times 100 \%}{64} \\
& =\frac{4500 \%}{64}
\end{aligned}
$$




$$
=70,31 \%
$$

b. Percobaan kedua

Diketahui:

Denyut nadi kerja $=143$

Denyut nadi istirahat $=75$

Denyut nadi maksimum $=140$

Ditanya: CVL (cardiovascular) ?

Jawab:

$$
\begin{aligned}
C V L & =\frac{(143-75) \times 100 \%}{140-75} \\
& =\frac{(68) \times 100 \%}{65} \\
& =\frac{6800 \%}{65} \\
& =104,62 \%
\end{aligned}
$$

10.3.3. Hubungan Denyut Jantung Dengan Energi Expenditur(Kuantitatif)

Dengan melihat data hasil praktikum modul biomekanika menggunakan alat tread mill, kita mencari hubungan antara hubungan denyut jantung dengan energi expenditur. Untuk menghitungnya dapat menggunakan metode kuantitatif regresi kuadratis. Regresi kuadratis dapat dirumuskan sebagai berikut:

$Y=K+a_{1} \cdot X_{1}+a_{2} \cdot X_{2}$

Dimana: 
$\mathrm{Y}=$ energi expenditure (kilo kalori per menit)

$\mathrm{K}=$ Konstanta

$\mathrm{X}=$ kecepatan denyut jantung (denyut per menit)

1. percobaan pertama

Diketahui:

$X=121$

Ditanya: $Y$ ?

Jawab:

$$
\begin{aligned}
Y & =1,80411-0,0229038 \cdot X+4,71733 \cdot 10^{-4} \cdot X^{2} \\
& =1,80411-0,0229038 \cdot 121+4,71733 \cdot 10^{-4} \cdot(121)^{2} \\
& =1,80411-2,7713598+0,000471733(14641) \\
& =-0,9672498+6,906642853 \\
& =5,939393053
\end{aligned}
$$

2. percobaan kedua

Diketahui:

$X=143$

Ditanya: $Y$ ?

Jawab:

$$
\begin{aligned}
Y & =1,80411-0,0229038 \cdot X+4,71733 \cdot 10^{-4} \cdot X^{2} \\
& =1,80411-0,0229038 \cdot 143+4,71733 \cdot 10^{-4} \cdot(143)^{2} \\
& =1,80411-3,2752434+0,000471733(20449) \\
& =-1,4711334+9,646468117 \\
& =8,175334717
\end{aligned}
$$




\subsection{Hubungan denyut jantung dengan energiexpenditure (SPSS)}

Dengan melihat data hasil praktikum modul biomekanika menggunakan alat tread mill, kita mencari hubungan antara hubungan denyut jantung dengan energi expenditur. Untuk menghitungnya dapat menggunakan metoderegresi linierdengan menggunakan bantuan software SPSS. Adapun data-datanya adalah sebagai berikut:

Tabel 4.1 Data Pengamatan Denyut Jantung dan Energi Expenditur

\begin{tabular}{|c|c|c|}
\hline Praktikum & Denyut jantung $(\mathrm{X})$ & Energi expenditur $(\mathrm{Y})$ \\
\hline 1 & 121 & 48 \\
\hline 2 & 143 & 59 \\
\hline 3 & 128 & 48 \\
\hline 4 & 104 & 30 \\
\hline 5 & 124 & 48 \\
\hline 6 & 134 & 79 \\
\hline 7 & 134 & 41 \\
\hline 8 & 131 & 30 \\
\hline 9 & 140 & 48 \\
\hline 10 & 120 & 30 \\
\hline 11 & 100 & 49 \\
\hline 12 & 122 & \\
\hline
\end{tabular}


Perhitungan hubungan denyut jantung dengan energi expenditur dengan menggunakan SPSS. Langkah-langkah nya yaitu sebagai berikut:

1. Masukkan semua data ke data view, dan akan muncul tampilan sebagai berikut:

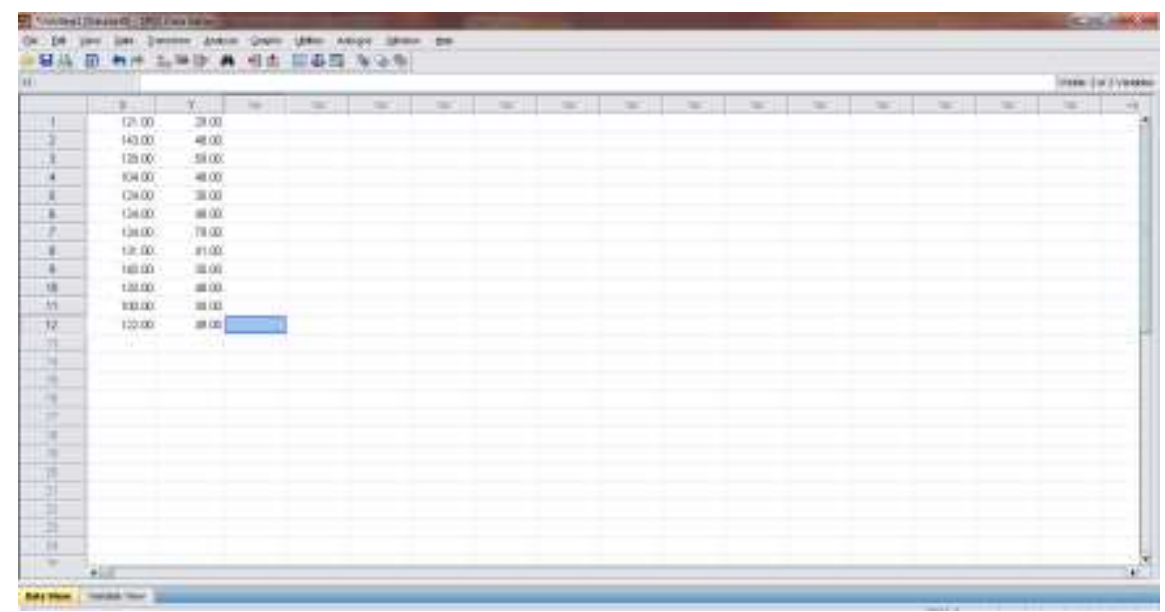

Gambar 4.1input data, data view

2. Klik analyze $\rightarrow$ regression $\rightarrow$ linear, dan akan muncul tampilan sebagai berikut: 


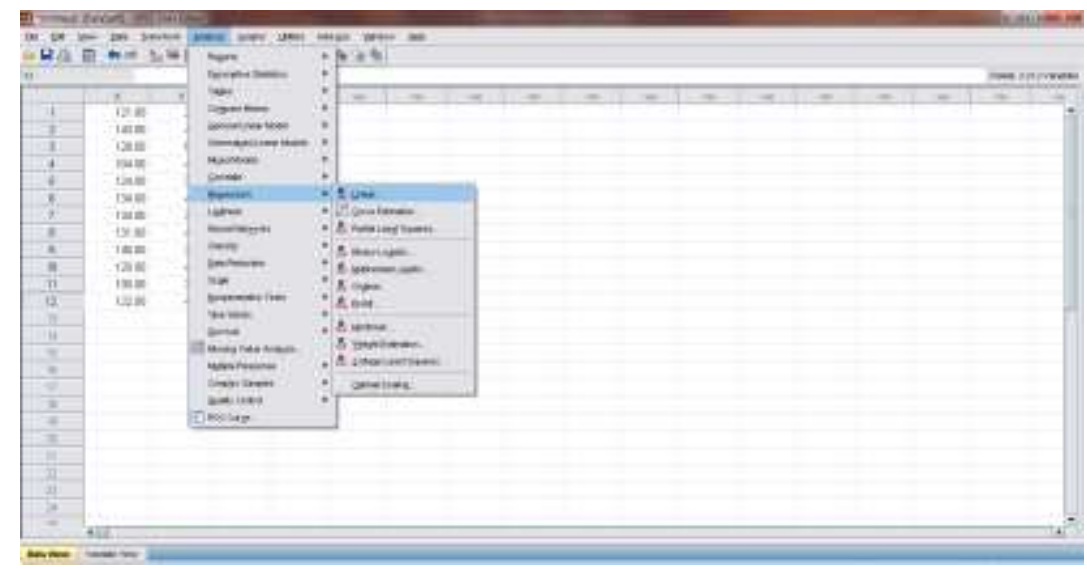

Gambar 4.2 menu analyze

3. Pada kotak dialog linier regression $\rightarrow$ klik variabel $\mathrm{Y}$ pada kotak dependent dengan menekan tanda

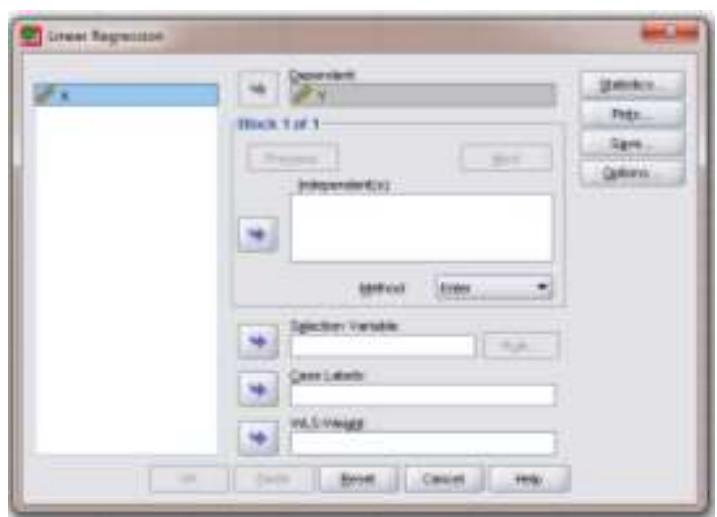

Gambar 4.3 kotak dialog linear regression variabel $Y$

4. Klik variabel X pada kotak independentdengan menekan tanda 


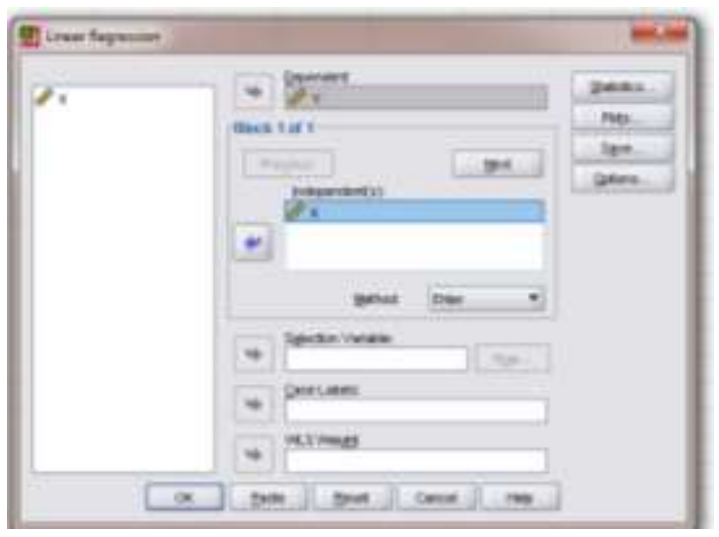

Gambar 4.4 kotak dialog linear regression variabel X

5. Klik statistic $\rightarrow$ estimates $\rightarrow$ model $\mathrm{fit} \rightarrow$ descriptive $\rightarrow$ continue.

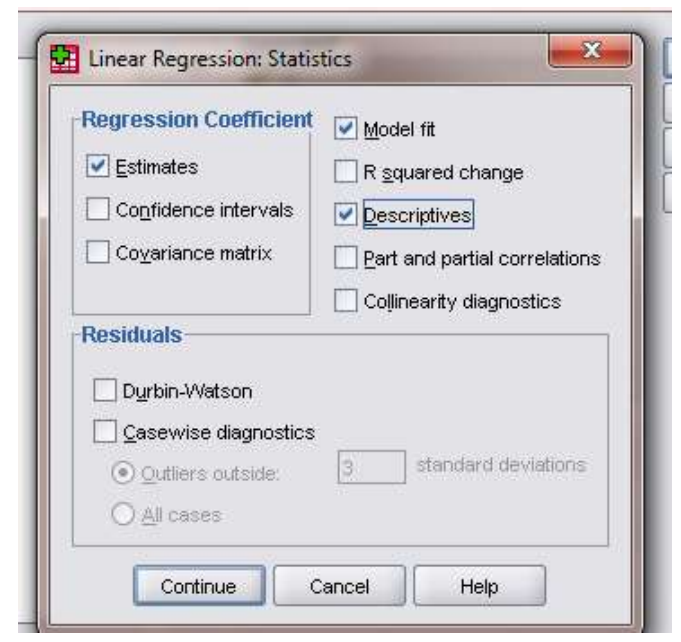

Gambar 4.5 kotak linear regression statistics 
6. Klik plots $\rightarrow$ masukkan dependent ke kotak y axis dan adjpred ke kotak $\mathrm{x}$ axis. Pilih histogram $\rightarrow$ normal probability $\rightarrow$ continue.

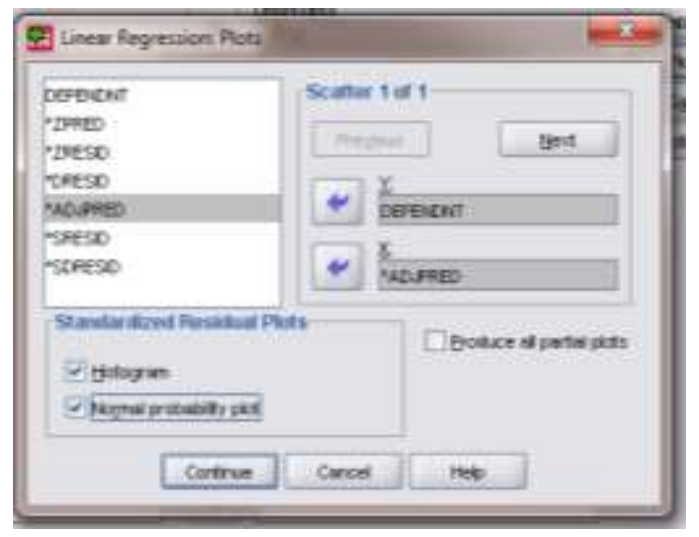

Gambar 4.6 kotak dialog linear regression plots

7. Klik save $\rightarrow$ Pada Predictive value pilih unstandardized $\rightarrow$ continue. 


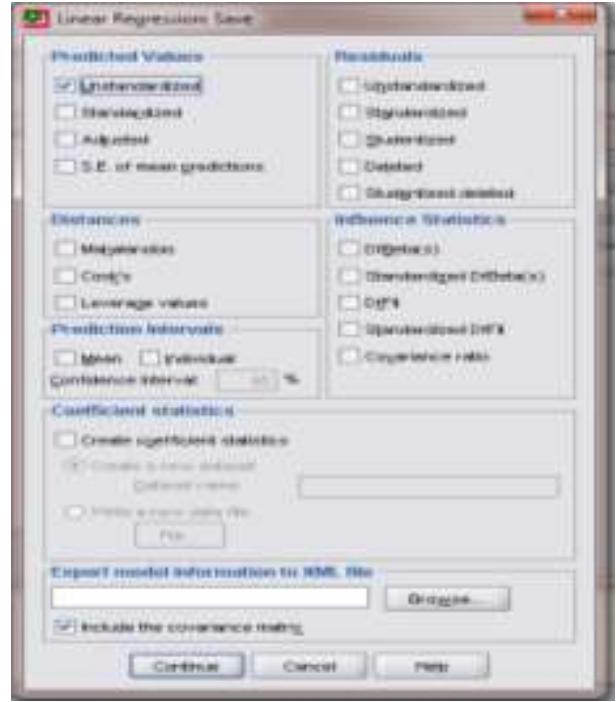

Gambar 4.7 kotak dialog linear regression save

8. Klik options $\rightarrow$ klik continue.

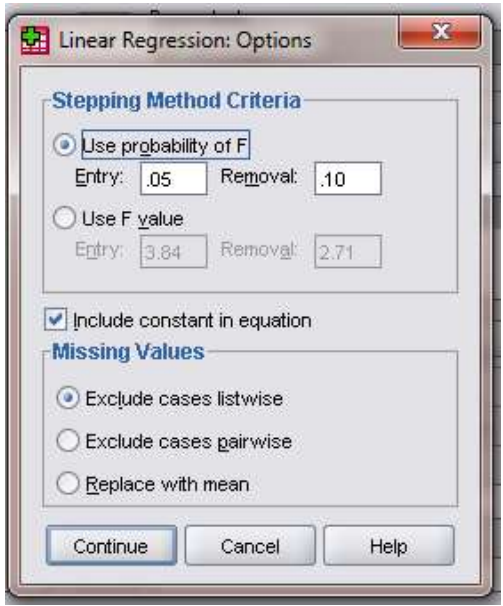

Gambar 4.8 dialog linear regression options

9. Kemudian klik ok, selanjutnya akan muncul output sebagai berikut: 
Descriptive Statistics

\begin{tabular}{|l|r|r|r|}
\hline & \multicolumn{1}{|c|}{ Mean } & Std. Deviation & \multicolumn{1}{|c|}{$N$} \\
\hline$Y$ & 44.9167 & 14.61916 & 12 \\
$X$ & $1.2508 E 2$ & 13.04857 & 12 \\
\hline
\end{tabular}

Correlations

\begin{tabular}{|ll|r|r|}
\hline & & \multicolumn{1}{|c|}{$Y$} & \multicolumn{1}{c|}{$X$} \\
\hline Pearson Correlation & $Y$ & 1.000 & .259 \\
& $X$ & .259 & 1.000 \\
\hline Sig. (1-tailed) & $Y$ & & .208 \\
& $X$ & .208 & \\
\hline $\mathrm{N}$ & $\mathrm{Y}$ & 12 & 12 \\
& $\mathrm{X}$ & 12 & 12 \\
\hline
\end{tabular}

Variables Entered/Removed ${ }^{\text {b }}$

\begin{tabular}{|l|l|l|l|}
\hline $\begin{array}{l}\text { Mode } \\
1\end{array}$ & $\begin{array}{c}\text { Variables } \\
\text { Entered }\end{array}$ & $\begin{array}{c}\text { Variables } \\
\text { Removed }\end{array}$ & Method \\
\hline 1 & $x^{2}$ &. & Enter \\
\hline
\end{tabular}

a. All requested variables entered.

b. Dependent Variable: $Y$

ANOVA ${ }^{b}$

\begin{tabular}{|ll|r|r|r|r|r|}
\hline \multicolumn{1}{|c|}{} & \multicolumn{1}{c|}{$\begin{array}{c}\text { Sum of } \\
\text { Squares }\end{array}$} & df & Mean Square & \multicolumn{1}{c|}{ F } & Sig. \\
\hline 1 & Regression & 158.057 & 1 & 158.057 & .721 & $.416^{=}$ \\
& Residual & 2192.860 & 10 & 219.286 & & \\
& Total & 2350.917 & 11 & & & \\
\hline
\end{tabular}

a. Predictors: (Constant), $X$

b. Dependent Variable: $Y$

Coefificients

\begin{tabular}{|c|c|c|c|c|c|c|}
\hline \multirow{2}{*}{\multicolumn{2}{|c|}{ Model }} & \multicolumn{2}{|c|}{ Unstandardized Coefficients } & \multirow{2}{*}{$\begin{array}{c}\text { Standardized } \\
\text { Coefficients } \\
\text { Beta } \\
\end{array}$} & \multirow[b]{2}{*}{$\mathrm{t}$} & \multirow[b]{2}{*}{ Siq. } \\
\hline & & $\mathrm{B}$ & Std. Error & & & \\
\hline 1 & (Constant) & 8.580 & 43.013 & & .199 & .846 \\
\hline & $x$ & .291 & .342 & .259 & .849 & .416 \\
\hline
\end{tabular}

a. Dependent Variable: $Y$

Gambar 4.9 output data perhitungan hubungan denyut jantung dengan energi expenditur menggunakan Software SPSS 
Residuals Statistics ${ }^{\text {a }}$

\begin{tabular}{|l|r|r|r|r|r|}
\hline & Minimum & Maximum & \multicolumn{1}{c|}{ Mean } & Std. Deviation & \multicolumn{1}{c|}{$\mathrm{N}$} \\
\hline Predicted Value & 37.6299 & 50.1215 & 44.9167 & 3.79062 & 12 \\
Std. Predicted Value & -1.922 & 1.373 & .000 & 1.000 & 12 \\
Standard Error of & 4.291 & 9.588 & 5.795 & 1.800 & 12 \\
Predicted Value & 34.4454 & 54.1269 & 45.1990 & 4.81117 & 12 \\
Adjusted Predicted Value & $-1.9250 \mathrm{E} 1$ & 31.49304 & .00000 & 14.11917 & 12 \\
Residual & -1.300 & 2.127 & .000 & .953 & 12 \\
Std. Residual & -1.455 & 2.275 & -.008 & 1.034 & 12 \\
Stud. Residual & $-2.4126 \mathrm{E} 1$ & 36.02433 & -.28237 & 16.69617 & 12 \\
Deleted Residual & -1.555 & 3.106 & .051 & 1.222 & 12 \\
Stud. Deleted Residual & .007 & 3.695 & .917 & 1.212 & 12 \\
Mahal. Distance & .000 & .372 & .093 & .121 & 12 \\
Cook's Distance & .001 & .336 & .083 & .110 & 12 \\
Centered Leverage Value & \multicolumn{5}{|c}{}
\end{tabular}

a. Dependent Variable: $Y$

Gambar 4.9 output data perhitungan hubungan denyut jantung dengan energi expenditur menggunakan Software SPSS

(Lanjutan...) 


\section{BAB. 11}

\section{BEBAN KERJA (WORK LOAD)}

Tubuh manusia dirancang untuk dapat melakukan aktivitas pekerjaan sehari-hari. Adanya massa otot yang bobotnya hampir lebih dari separuh berat tubuh, memungkinkan kita untuk dapat menggerakkan tubuh dan melakukan pekerjaan. Pekerjaan di satu pihak mempunyai arti penting bagi kemajuan dan peningkatan prestasi, sehingga mencapai kehidupan yang produktif sebagai salah satu tujuan hidup. Di pihak lain, dengan bekerja berarti tubuh akan menerima beban dari luar tubuhnya. Dengan kata lain bahwa setiap pekerja merupakan beban bagi yang bersangkutan. Beban tersebut dapat berupa beban fisik maupun beban mental.

Dari sudut pandang ergonomi, setiap beban kerja yang diterima oleh seseorang harus sesuai atau seimbang baik terhadap kemampuan fisik, kemampuan kognitif maupun keterbatasan manusia yang menerima beban tersebut. Menurut Suma'mur (1984) bahwa kemampuan kerja seorang tenaga kerja berbeda dari satu kepada yang lainnya dan sangat tergantung dari tingkat keterampilan, kesegaran jasmani, keadaan gizi, jenis kelamin, usia dan ukuran tubuh dari pekerja yang bersangkutan. 


\subsection{Faktor yang Mempengaruhi Beban Kerja}

Menurut Ridahl (1989), Adiputra (1998) dan Manuaba (2000) bahwa secara umum hubungan antara beban kerja dan kapasitas kerja dipengaruhi oleh berbagai faktor yang sangat komplek, baik faktor internal maupun faktor eksternal.

\subsubsection{Beban Kerja Karena Faktor Eksternal}

Faktor eksternal beban kerja adalah beban kerja yang berasal dari luar tubuh pekerja. Yang termasuk beban kerja eksternal adalah tugas (task) itu sendiri, organisasi dan lingkungan kerja. Ketiga aspek ini sering disebut sebagai stressor

1. Tugas-tugas (task) yang dilakukan baik yang bersifat fisik seperti, stasiun kerja, tata ruang tempat kerja, alat dan sarana kerja, kondisi atau medan kerja, sikap kerja, cara angkat-angkut, beban yang diangkat-angkut, alat bantu kerja, sarana informasi termasuk displai dan control, alur kerja dll. Sedangkan tugas-tugas yang bersifat mental seperti, kompleksitas pekerjaan atau tingkat kesulitan pekerjaan yang mempengaruhi tingkat emosi pekerja, tanggung jawab pekerjaan dll.

2. Organisasi kerja yang dapat mempengaruhi beban kerja seperti, lamanya waktu kerja, waktu istirahat, kerja bergilir, kerja malam, sistem pengupahan, sistem kerja, 
musik kerja, model struktur organisasi, pelimpahan tugas dan wewenang dll.

3. Lingkungan kerja yang dapat memberikan beban tambahan kepada pekerja adalah ;

$>$ Lingkungan kerja fisik seperti; mikroklimat (suhu udara ambien, kelembaban udara, kecepatan tambat udara, suhu radiasi), intensitas penerangan, intensitas kebisingan, vibrasi mekanis, dan tekanan udara.

> Lingkungan kerja kimiawi seperti; debu, gas-gas pencemar udara, uap logam, fume dalam udara dll.

> Lingkungan kerja biologis seperti; bakteri, virus dan parasit, jamur, serangga dll.

> Lingkungan kerja psikologis seperti; pemilihan dan penempatan tenaga kerja, hubungan antara pekerja dan pekerja, pekerja dengan atasan, pekerja dengan keluarga dan pekerja dengan lingkungan sosial yang berdampak kepada performansi kerja di tempat kerja.

\subsubsection{Beban Kerja Karena Faktor Internal}

Faktor internal beban kerja adalah faktor yang berasal dari dalam tubuh itu sendiri sebagai akibat adanya reaksi dari beban kerja eksternal. Reaksi tubuh tersebut dikenal sebagai 
strain. Berat ringannya strain dapat dinilai baik secara obyektif maupun subyektif. Penilaian secara objektif yaitu melalui perubahan reaksi fisiologis. Sedangkan penilaian subjektif dapat dilakukan melalui perubahan reaksi psikologis dan perubahan prilaku. Karena itu strain secara subjektif berkait erat dengan harapan, keinginan, kepuasan dan penilaian subjektif lainnya. Secara lebih ringkas faktor internal meliputi :

a) Faktor somatis (jenis kelamin, umur, ukuran tubuh, kondisi kesehatan, status gizi); serta

b) faktor psikis (motivasi, persepsi, kepercayaan, keinginan, kepuasan dll)

\subsection{Penilaian Beban Kerja Fisik}

Menurut Astrand\& Rodahl (1977) dan Rodahl (1989) bahwa penilaian beban kerja fisik dapat dilakukan secara dua metode objektif, yaitu metode penilaian langsung dan metode tidak langsung. Metode pengukuran langsung yaitu dengan mengukur energi yang dikeluarkan (energy expenditure) melalui asupan oksigen selama bekerja. Semakin berat beban kerja semakin banyak energi yang diperlukan atau dikonsumsi. Meskipun metode dengan menggunakan asupan oksigen lebih akurat, namun hanya dapat mengukur untuk waktu kerja yanag singkat dan diperlukan peralatan yang cukup 
mahal. Sedangkan metode pengukuran tidak langsung adalah dengan menghitung denyut nadi selama kerja.

Lebih lanjut Christensen (1991) dan Grandjean (1993) menjelaskan bahwa salah satu pendekatan untuk mengetahui berat ringannya beban kerja adalah dengan menghitung nadi kerja, konsumsi oksigen, kapasitas ventilasi paru dan suhu inti tubuh. Pada batas tertentu ventilasi paru, denyut jantung dan suhu tubuh mempunyai hubungan yang linier dengan konsumsi oksigen atau pekerjaan yang dilakukan. Kemudian Konz (1996) mengemukakan bahwa denyut jantung adalah suatu alat estimasi laju metabolisme yang baik, kecuali dalam keadaan emosi dan vasolodasi. Kategori berat ringannya beban kerja didasarkan pada metabolisme, respirasi, suhu dan denyut jantung menurut Christensen (1991) dapat dilihat pada tabel 7.1

Tabel 7.1 Kategori Beban Kerja Berdasarkan Metabolisme, Respirasi, Suhu Tubuh dan Denyut Jantung

\begin{tabular}{|c|c|c|c|c|}
\hline $\begin{array}{c}\text { Kategori } \\
\text { beban Kerja }\end{array}$ & $\begin{array}{c}\text { Konsumsi } \\
\text { Oksigen } \\
(1 / \mathrm{min})\end{array}$ & $\begin{array}{c}\text { Ventilasi } \\
\text { Paru(1/min) }\end{array}$ & $\begin{array}{c}\text { Suhu } \\
\text { (Rektal ( } \\
\left.{ }^{\circ} \mathrm{C}\right)\end{array}$ & $\begin{array}{c}\text { Denyut } \\
\text { Jantung } \\
\text { (denyut/min) }\end{array}$ \\
\hline Ringan & $0,5-1,0$ & $11-20$ & 37,5 & $75-100$ \\
Sedang & $1,0-1,5$ & $20-31$ & $37,5-$ & $100-125$ \\
Berat & $1,5-2,0$ & $31-43$ & 38,0 & $125-150$ \\
Sangat & $2,0-2,5$ & $43-56$ & $38,0-$ & $150-175$ \\
berat & $2,5-4,0$ & $60-100$ & 38,5 & $>175$ \\
\hline
\end{tabular}




\begin{tabular}{|c|l|l|c|c|}
\hline Sangat & & & $38,5-$ & \\
berat sekali & & & 39,0 & \\
& & & $>39$ & \\
\hline
\end{tabular}

Sumber : Christensen (1991:1699). Encyclopaedia of Occupational Headlth and Safety.II.O.Geneva

Berat ringannya beban kerja yang diterima oleh seorang tenaga kerja dapat digunakan untuk menentukan berapa lama seorang tenaga kerja dapat melakukan aktivitas pekerjaannya sesuai dengan kemampuan atau kapasitas kerja yang bersangkutan. Di mana samakin berat beban kerja, maka akan semakin pendek waktu kerja seseoarang untuk bekeja tanpa kelelahan dan gangguan fisiologis yang berarti atau sebaliknya.

\subsection{Penilaian Beban Kerja Berdasarkan Jumlah Kebutuhan Kalori}

Salah satu kebutuhan utama dalam pergerakan otot adalah kebutuhan akan oksigen yang dibawa oleh darah ke otot untuk pembakaran zat dalam menghasilkan energi. Sehingga jumlah oksigen yang dipergunakan oleh tubuh untuk bekerja merupakan salah satu indikator pembebanan selama bekerja. Dengan demikian setiap aktivitas pekerjaan memerlukan energi yang dihasilkan dari proses pembakaran. Semakin berat pekerjaan yang dilakukan maka akan semakin besar pula energi yang dikeluarkan. Berdasarkan hal 
tersebut maka besarnya jumlah kebutuhan kalori dapat digunakan sebagai petunjuk untuk menentukan berat ringannya beban kerja.

Berkaitan dengan hal tersebut, Menteri Tenaga Kerja melalui Keputusan Nomor 51 (1999) menetapkan kategori beban kerja menurut kebutuhan kalori sebagai bertikut :

$>$ Beban kerja ringan : 100-200 Kilo kalori/jam

$>$ Beban kerja sedang: >200-350 Kilo kalori/jam

$>$ Beban kerja berat $\quad$ : $>350-500$ Kilo kalori/jam

Kebutuhan kalori dapat dinyatakan dalam kalori yang dapat diukur secara tidak langsung dengan menentukan kebutuhan oksigen. Setiap kebutuhan 1 liter oksigen akan memberikan 4,8 Kilo kalori (Suma'mur, 1982). Sebagai dasar perhitungan dalam menentukan jumlah kalori yang dibutuhkan oleh seseorang dalam melakukan aktivitas pekerjaannya, dapat dilakukan melalui pendekatan atau taksiran kebutuhan kalori menurut jenis aktivitasnya. Taksiran kebutuhan kalori per jam untuk setiap kg badan dapat dilihat pada table 7.2 
Tabel 7.2 Kebutuhan Kalori Per Jam Menurut Jenis Aktivitas

\begin{tabular}{|c|l|c|}
\hline No. & \multicolumn{1}{|c|}{ Jenis Aktivitas } & Kilo kalori/jam/kg \\
& & Berat badan \\
\hline 1 & Tidur & 0,98 \\
3 & Duduk dalam keadaan istirahat & 1,43 \\
4 & Membaca dengan intonasi keras & 1,50 \\
5 & Merdiri dalam keadaan tenang & 1,50 \\
6 & Berdiri dengan konsentrasi terhadap & 1,59 \\
7 & sesuatu objek & 1,63 \\
8 & Berpakaian & 1,69 \\
9 & Menyanyi & 1,74 \\
10 & Menjahit dengan mesin & 1,93 \\
11 & Mengetik & 2,00 \\
12 & Menyetrika (berat setrika $\pm 2,5$ kg) & 2,06 \\
13 & Mencuci peralatan dapur & 2,06 \\
14 & Menyapu lantai dengan kecepatan \pm 38 & 2,41 \\
15 & kali per menit & 2,43 \\
16 & Menjilid buku & 2,43 \\
17 & Pelatihan ingan (light exercise) & 2,86 \\
18 & Jalan ringan kecepatan $\pm 3,9$ km/jam & 4,20 \\
\hline 19 & Pekerjaan kayu, logam dan pengecastan & \\
\hline
\end{tabular}




\begin{tabular}{|l|l|l|}
\hline 21 & Pelatihan sedang (moderate exercise) & 5,71 \\
22 & Jalan agak cepat dengan kecepatan & 6,43 \\
23 & $\pm 5,6 \mathrm{~km} / \mathrm{jam}$ & 6,86 \\
24 & Jalan turun tangga & 7,14 \\
25 & Pekerjaan tukang batu & 8,14 \\
26 & Pelatihan beat (heavy exercise) & 8,57 \\
27 & Penggergajian kayu secara manual & 9,28 \\
28 & Berenang & 15,80 \\
& Lari dengan kecepatan \pm 8 km/jam & \\
& Pelatihan sangat berat (very heavy & \\
& exercise) & \\
& Berjalan sangat cepat dengan kecepatan & \\
& \pm 8 km/jam & \\
& Jalan naik tangga & \\
\hline
\end{tabular}

Sumber: Suma'mur (1982) dikutip dari Sherman,H.C Chemistry food and Nutrition 


\section{BAB. 12 \\ ANALISA PERANCANGAN KURSI KULIAH YANG ERGONOMIS}

\subsection{Data Hasil Pengamatan}

Pada bab ini akan menjelaskan mengenai implementasi metode Anthropometri untuk menciptakan kursi kuliah yang ergonomis dan sesuai dengan dimensi tubuh mahasiswa Teknik Industri Angkatan Tahun 2017. Adapun data yang dicari adalah dimensi: Tinggi Duduk Tegak (TDT), Jangkauan Tangan Depan (JTD), Lebar Bahu (LB), Panjang Tangan (PT).

Tabel 3.1 Data Hasil Pengamatan

\begin{tabular}{|c|c|c|c|c|c|}
\hline \multirow[b]{2}{*}{ No } & \multirow[b]{2}{*}{ Nama } & \multicolumn{4}{|c|}{ Data Pengamatan } \\
\hline & & $\begin{array}{l}\text { TDT } \\
(\mathrm{cm})\end{array}$ & $\begin{array}{l}\text { JTD } \\
(\mathrm{cm})\end{array}$ & $\begin{array}{l}\text { LB } \\
(\mathrm{cm})\end{array}$ & $\begin{array}{c}\text { PT } \\
(\mathrm{cm})\end{array}$ \\
\hline 1 & Didin & 66,4 & 82,5 & 38,5 & 19 \\
\hline 2 & Arbaun & 68 & 76 & 36,5 & 18 \\
\hline 3 & Ika & 64 & 77 & 36,5 & 16 \\
\hline 4 & Sakinah & 67,2 & 77,2 & 38 & 17 \\
\hline 5 & Ardi & 69 & 82 & 38 & 16 \\
\hline & $\sum \mathrm{X}$ & 334,6 & 394,7 & 187,5 & 86 \\
\hline & $\Sigma X)^{2}$ & 22.405 & 31.195, & $7.034,7$ & 1.486 \\
\hline
\end{tabular}




\begin{tabular}{|c|c|c|c|c|}
\hline &, 8 & 09 & 5 & \\
& 111.95 & 155.788 & 35.156, & 7.396 \\
& 7,16 &, 09 & 25 & \\
\hline$X$ & 66,92 & 78,94 & 37,5 & 17,2 \\
\hline
\end{tabular}

\subsection{Langkah Kerja}

Adapun langkah kerja dari praktikum perancangan sistem kerja dan ergonomi modul anthropometri dapat diuraikan sebagai berikut :

1. Menyiapkan alat dan bahan yang akan digunakan.

2. Menetapkan manusia yang akan diukur anggota tubuh badannya.

3. Menyiapkan kertas untuk mencatat hasil pengukuran.

4. Melakukan proses pengukuran dimensi tubuh yang akan diukur menggunakan alat anthropometer.

\subsection{Pengolahan Data}

Pada pengolahan data ini akan menghitung kecukupan data, waktu deviasi, BKA,BKB, dan persentil. Dalam beberapa pengukuran yaitu Tinggi Duduk Tegak (TDT), Jangkauan Tangan Depan (JTD), Lebar Bahu (LB), Panjang Tangan (PT).

\subsubsection{Pengukuran Tinggi Duduk Tegak (TDT)}

Pada proses pengukuran tinggi duduk tegak ini akan dijelaskan mengenai perhitungan kecukupan data, standard deviasi, uji 
keseragaman data, dan persentil dari praktikum modul antropometri. Adapun hasil perhitungannya adalah sebagai berikut :

Tabel 4.1 Data Pengukuran Tinggi Duduk Tegak

\begin{tabular}{|c|c|c|}
\hline No & Nama & Tinggi Duduk Tegak \\
\hline 1 & Didin & 66,4 \\
\hline 2 & Arba'un & 68 \\
\hline 3 & Ika & 64 \\
\hline 4 & Sakinah & 67,2 \\
\hline 5 & Ardi & 69 \\
\hline
\end{tabular}

$$
\begin{array}{ll}
\Sigma X & =334,6 \\
(\Sigma X)^{2} & =111957,16 \\
\Sigma X^{2} & =22405,8 \\
\bar{X} & =66,92 \\
k & =2 \\
s & =0,05
\end{array}
$$

1. Kecukupan Data

Berikut ini adalah perhitungan kecukupan data pada pengukuran tinggi duduk tegak :

$$
\begin{aligned}
N^{\prime} & =\left[\frac{\frac{\mathrm{k}}{\mathrm{s}} \sqrt{\mathrm{N} \cdot \sum \mathrm{X}^{2}-\left(\sum \mathrm{X}\right)^{2}}}{\sum \mathrm{X}}\right]^{2} \\
& =\left[\frac{\frac{2}{0,05} \sqrt{5 \cdot(22405,8)-(111957,16)}}{334,6}\right]^{2}
\end{aligned}
$$




$$
\begin{aligned}
& =\left[\frac{40 \sqrt{112029-111957,16}}{334,6}\right]^{2} \\
& =\left[\frac{40 \sqrt{71,84}}{334,6}\right]^{2} \\
& =\left[\frac{40 \mathrm{x} 8,48}{334,6}\right]^{2} \\
& =\left[\frac{339,2}{334,6}\right]^{2} \\
& =[1,013]^{2} \\
& =1,03 \text { (Data cukup) karena } \mathrm{N}^{\prime}<\mathrm{n} .
\end{aligned}
$$

2. Uji Keseragaman Data

Berikut ini adalah perhitungan standard deviasi pada pada pengukuran tinggi duduk tegak :

$$
\sigma=\sqrt{\frac{\sum\left(\mathrm{X}_{\mathrm{i}}-\overline{\mathrm{X}}\right)^{2}}{\mathrm{n}-1}}
$$

$$
\begin{aligned}
& =\sqrt{\frac{(66,4-66,92)^{2}+(68-66,92)^{2}+(64-66,92)^{2}+(67,2-66,92)^{2}}{+(69-66.92)}} \begin{array}{c}
5-1 \\
=\sqrt{\frac{(-0,52)^{2}+(1,08)^{2}+(-2,92)^{2}+(0,28)^{2}+(2,08)^{2}}{4}}
\end{array} \\
& =\sqrt{\frac{0,27+1,17+8,53+0,08+4,33}{4}}
\end{aligned}
$$




$$
\begin{aligned}
& =\sqrt{\frac{14,38}{4}} \\
& =\sqrt{3,59} \\
& =1,90
\end{aligned}
$$

Berikut ini adalah perhitungan BKA dan BKB pada pengukuran tinggi duduk tegak :

$$
\begin{aligned}
& \mathrm{BKA}=\overline{\mathrm{X}}+\mathrm{k} \times \sigma=66,92+(2 \times 1,90)=66,92+3,79=70,71 \\
& \mathrm{BKB}=\overline{\mathrm{X}}-\mathrm{k} \times \sigma=66,92-(2 \times 1,90)=66,92-3,79=63,13
\end{aligned}
$$

Sehingga dapat disimpulkan bahwa hasil uji keseragaman data adalah :

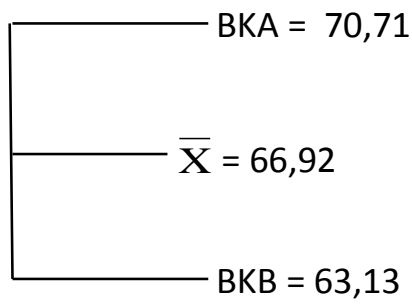

Berikut adalah gambar grafik dalam perhitungan antropometri pengukuran Tinggi Duduk Tegak (TDT). 


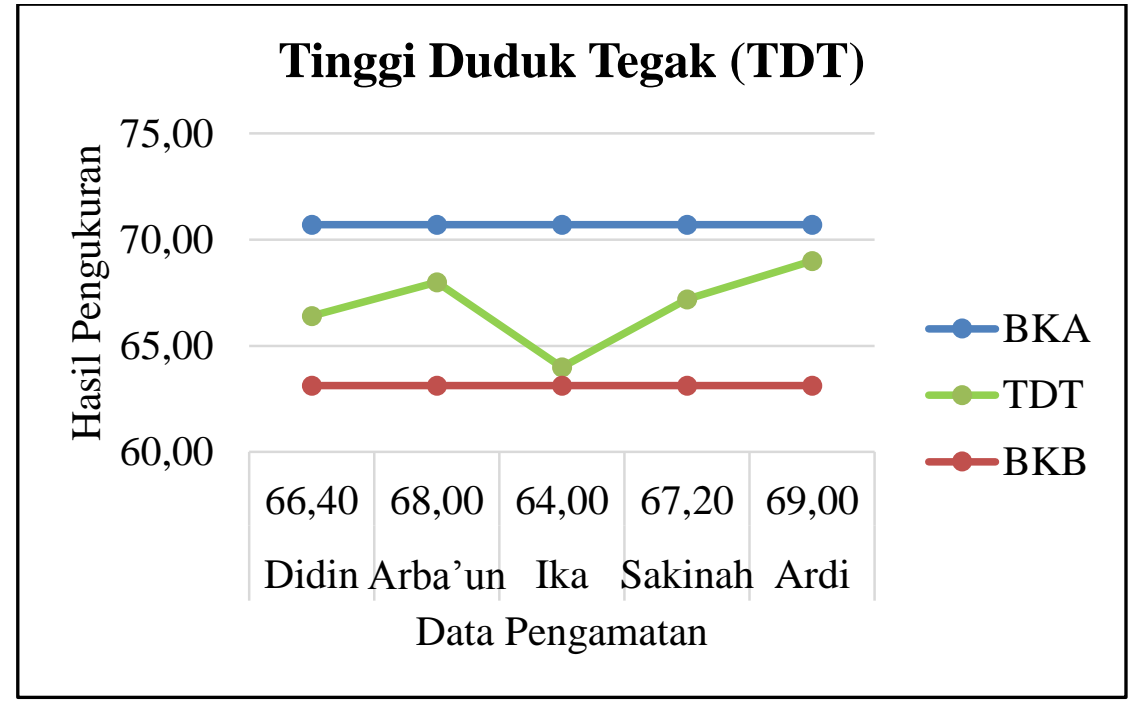

Gambar 4.1 Grafik Pengukuran Tinggi Duduk Tegak (TDT)

Dari hasil kesimpulan diatas dapat dikatakan bahwa tidak ada data ekstrim pada tabel pengamatan pengukuran tinggi duduk tegak.

3. Menghitung Persentil

$$
\begin{aligned}
\text { Persentil } 5 \%= & \bar{X}-(1,645 \times \sigma) \\
& =66,92-(1,645 \times 1,90) \\
& =66,92-3,12 \\
& =63,80
\end{aligned}
$$

Persentil $50 \%=\overline{\mathrm{X}}=66,92$

Persentil $95 \%=\bar{X}+(1,645 \times \sigma)$

$$
\begin{aligned}
& =66,92+(1,645 \times 1,90) \\
& =66,92+3,12 \\
& =70,04
\end{aligned}
$$




\subsubsection{Pengukuran Jangkauan Tangan Depan (JTD)}

Pada proses pengukuran jangkauan tangan depan ini akan dijelaskan mengenai perhitungan kecukupan data, standard deviasi, uji keseragaman data, dan persentil dari praktikum modul antropometri. Adapun hasil perhitungannya adalah sebagai berikut:

Tabel 4.2 Data Jangkauan Tangan Depan

\begin{tabular}{|c|c|c|}
\hline No & Nama & Jangkauan Tangan Depan \\
\hline 1 & Didin & 82,5 \\
\hline 2 & Arba'un & 76 \\
\hline 3 & Ika & 77 \\
\hline 4 & Sakinah & 77,2 \\
\hline 5 & Ardi & 82 \\
\hline
\end{tabular}

$$
\begin{array}{ll}
\Sigma X & =394,7 \\
(\Sigma X)^{2} & =155788,09 \\
\Sigma X^{2} & =31195,09 \\
\bar{X} & =78,94 \\
k & =2 \\
s & =0,05
\end{array}
$$

1. Kecukupan Data

Berikut ini adalah perhitungan kecukupan data pada jangkauan tangan depan:

$$
\mathrm{N}^{\prime}=\left[\frac{\frac{\mathrm{k}}{\mathrm{s}} \sqrt{\mathrm{N} \cdot \sum \mathrm{X}^{2}-\left(\sum \mathrm{X}\right)^{2}}}{\sum \mathrm{X}}\right]^{2}
$$




$$
\begin{aligned}
& =\left[\frac{\frac{2}{0,05} \sqrt{5 \cdot(31195,09)-(155788,09)}}{394,7}\right]^{2} \\
& =\left[\frac{40 \sqrt{155975,45-155788,09}}{394,7}\right]^{2} \\
& =\left[\frac{40 \sqrt{187,36}}{394,7}\right]^{2} \\
& =\left[\frac{40 \times 13,69}{394,7}\right]^{2} \\
& =\left[\frac{547,6}{394,7}\right]^{2} \\
& =[1,39]^{2} \\
& =1,92 \text { (Data cukup) karena } N^{\prime}<\mathrm{n} .
\end{aligned}
$$

2. Uji Keseragaman Data

Berikut ini adalah perhitungan standarddeviasi pada pengukuran jangkauan tangan depan:

$$
\begin{aligned}
\sigma & =\sqrt{\frac{\sum\left(\mathrm{X}_{\mathrm{i}}-\overline{\mathrm{X}}\right)^{2}}{\mathrm{n}-1}} \\
& =\sqrt{\frac{(82,5-78,94)^{2}+(76-78,94)^{2}+(77-78,94)^{2}+(77,2-78,94)^{2}}{+(82-78,94)^{2}}} \frac{5-1}{4} \\
& =\sqrt{\frac{(3,56)^{2}+(-2,94)^{2}+(-1,94)^{2}+(-1,74)^{2}+(3,06)^{2}}{4}}
\end{aligned}
$$




$$
\begin{aligned}
& =\sqrt{\frac{12,67+8,64+3,76+3,03+9,36}{4}} \\
& =\sqrt{\frac{37,46}{4}} \\
& =\sqrt{9,37} \\
& =3,06
\end{aligned}
$$

Berikut ini adalah perhitungan BKA dan BKB pada pengukuran jangkauan tangan depan :

$$
\begin{aligned}
& \mathrm{BKA}=\overline{\mathrm{X}}+\mathrm{k} \times \sigma=78,94+(2 \times 3,06)=78,94+6,12=85,06 \\
& \mathrm{BKB}=\overline{\mathrm{X}}-\mathrm{k} \times \sigma=78,94-(2 \times 3,06)=78,94-6,12=72,82
\end{aligned}
$$

Sehingga dapat disimpulkan bahwa hasil uji keseragaman data

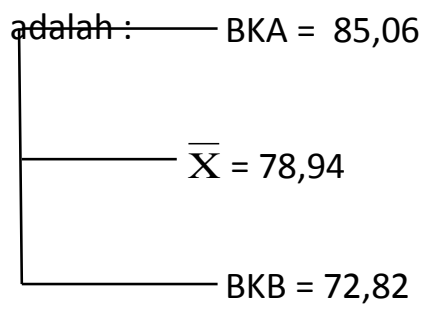

Berikut adalah gambar grafik dalam perhitungan antropometri pengukuran Jangkauan Tangan Depan (JTD). 


\section{Jangkauan Tangan Depan (JTD)}

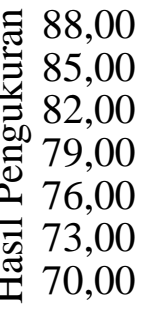

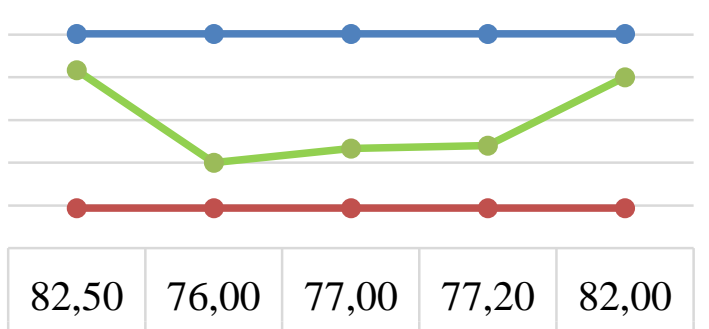

$\rightarrow$ BKA

- JDT

$\rightarrow \mathrm{BKB}$

Didin Arba'un Ika Sakinah Ardi

Data Pengamatan

Gambar 4.2 Grafik Pengukuran Jangkauan Tangan Depan (JTD)

Dari hasil kesimpulan diatas dapat dikatakan bahwa tidak ada data ekstrim pada tabel pengamatan pengukuran jangkauan tangan depan.

2. Menghitung Persentil

Persentil $5 \%=\overline{\mathrm{X}}-(1,645 \times \sigma)$

$$
\begin{aligned}
& =78,94-(1,645 \times 3,06) \\
& =78,94-5,03 \\
& =73,91
\end{aligned}
$$

Persentil 50\% $=\overline{\mathrm{X}}=78,94$

Persentil 95\% $=\bar{X}+(1,645 \times \sigma)$

$$
\begin{aligned}
& =78,94+(1,645 \times 3,06) \\
& =78,94+5,03 \\
& =83,9
\end{aligned}
$$




\subsubsection{Pengukuran Lebar Bahu (LB)}

Pada proses pengukuran lebar bahu ini akan dijelaskan mengenai perhitungan kecukupan data, standard deviasi, uji keseragaman data, dan persentil dari praktikum modul antropometri. Adapun hasil perhitungannya adalah sebagai berikut :

Tabel 4.3 Data Pengukuran Lebar Bahu

\begin{tabular}{|c|c|c|}
\hline No & Nama & Lebar Bahu \\
\hline 1 & Didin & 38,5 \\
\hline 2 & Arba'un & 36,5 \\
\hline 3 & Ika & 36,5 \\
\hline 4 & Sakinah & 38 \\
\hline 5 & Ardi \\
$\Sigma X$ & $=187,5$ \\
$(\Sigma X)^{2}$ & $=35156,25$ \\
$\Sigma X^{2}$ & $=7034,75$ \\
$\bar{X}$ & $=37,5$ \\
$k$ & $=2$ \\
$s$ & $=0,05$
\end{tabular}

1. Kecukupan Data

Berikut ini adalah perhitungan kecukupan data pada pengukuran jangkauan tangan atas:

$$
\mathrm{N}^{\prime}=\left[\frac{\frac{\mathrm{k}}{\mathrm{s}} \sqrt{\mathrm{N} \cdot \Sigma \mathrm{X}^{2}-(\Sigma \mathrm{X})^{2}}}{\sum \mathrm{X}}\right]^{2}
$$




$$
\begin{aligned}
& =\left[\frac{\frac{2}{0,05} \sqrt{5 \cdot(7034,75)-35156,25}}{187,5}\right]^{2} \\
& =\left[\frac{40 \sqrt{35173,75-35156,25}}{187,5}\right]^{2} \\
& =\left[\frac{40 \sqrt{17,5}}{187,5}\right]^{2} \\
& =\left[\frac{40 \times 4,18}{187,5}\right]^{2} \\
& =\left[\frac{167,2}{187,5}\right]^{2} \\
& =[0,89]^{2} \\
& =0,80 \text { (Data cukup) karena } \mathrm{N}^{\prime}<\mathrm{n} .
\end{aligned}
$$

2. Uji Keseragaman Data

Berikut ini adalah perhitungan standard deviasi pada pengukuran jangkauan tangan atas :

$$
\begin{aligned}
\sigma & =\sqrt{\frac{\sum\left(\mathrm{X}_{\mathrm{i}}-\overline{\mathrm{X}}\right)^{2}}{\mathrm{n}-1}} \\
& =\sqrt{\frac{(38,5-37,5)^{2}+(36,5-37,5)^{2}+(36,5-37,5)^{2}+(38-37,5)^{2}}{+(38-37,5)^{2}}} \frac{5-1}{4} \\
& =\sqrt{\frac{(1)^{2}+(-1)^{2}+(-1)^{2}+(0,5)^{2}+(0,5)^{2}}{4}}
\end{aligned}
$$




$$
\begin{aligned}
& =\sqrt{\frac{1+1+1+0,25+0,25}{4}} \\
& =\sqrt{\frac{3,5}{4}} \\
& =\sqrt{0,88} \\
& =0,94
\end{aligned}
$$

Berikut ini adalah perhitungan BKA dan BKB pada pengukuran jangkauan tangan atas :

$$
\begin{aligned}
& \mathrm{BKA}=\overline{\mathrm{X}}+\mathrm{k} \times \sigma=37,5+(2 \times 0,94)=37,5+1,87=39,37 \\
& \mathrm{BKB}=\overline{\mathrm{X}}-\mathrm{k} \times \sigma=37,5-(2 \times 0,94)=37,5-1,87=35,63
\end{aligned}
$$

Sehingga dapat disimpulkan bahwa hasil uji keseragaman data adalah :

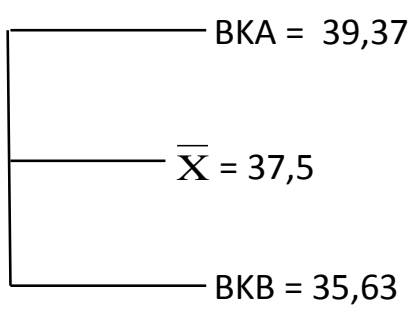

Berikut adalah gambar grafik dalam perhitungan antropometri pengukuran Lebar Bahu (LB). 


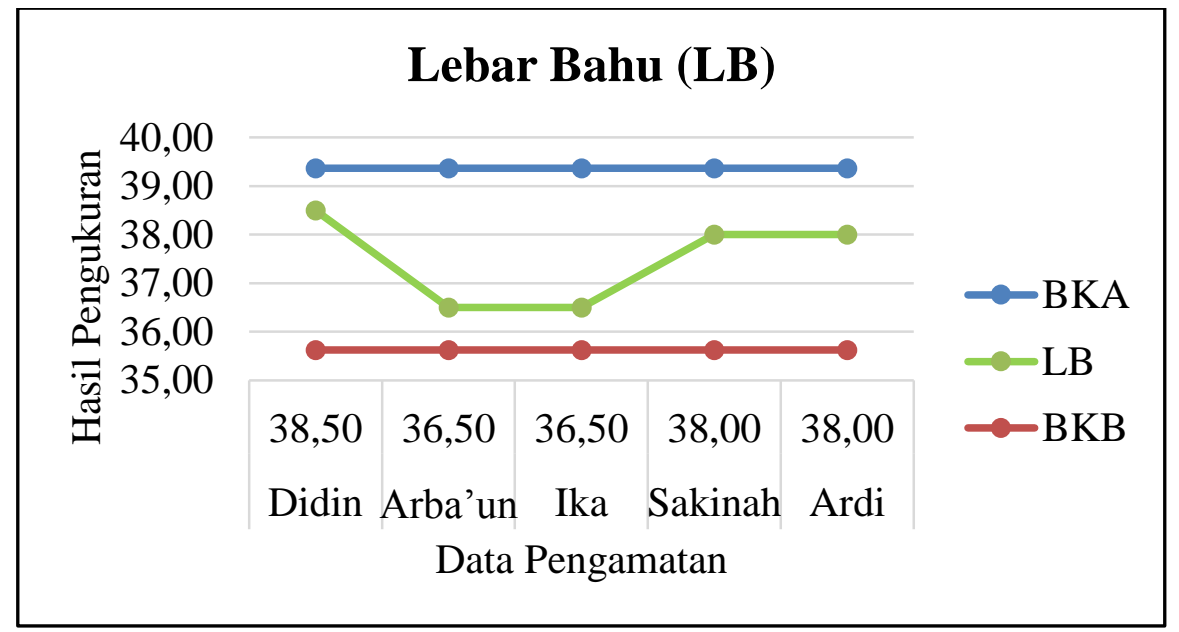

Gambar 4.3 Grafik Pengukuran Lebar Bahu (LB)

Dari hasil kesimpulan diatas dapat dikatakan bahwa tidak ada data ekstrim pada tabel pengamatan pengukuran lebar bahu.

3. Menghitung Persentil

$$
\begin{aligned}
\text { Persentil } 5 \%= & \bar{X}-(1,645 \times \sigma) \\
& =37,5-(1,645 \times 0,94) \\
& =37,5-1,54 \\
& =35,96
\end{aligned}
$$

Persentil $50 \%=\overline{\mathrm{X}}=37,5$

Persentil 95\% $=\overline{\mathrm{X}}+(1,645 \times \sigma)$

$$
\begin{aligned}
& =37,5+(1,645 \times 0,94) \\
& =37,5+1,54 \\
& =39,04
\end{aligned}
$$




\subsubsection{Pengukuran Panjang Tangan (PT)}

Pada proses pengukuran panjang tangan ini akan dijelaskan mengenai perhitungan kecukupan data, standard deviasi, uji keseragaman data, dan persentil dari praktikum modul antropometri. Adapun hasil perhitungannya adalah sebagai berikut :

Tabel 4.4 Data Pengukuran Panjang Tangan

\begin{tabular}{|c|c|c|}
\hline No & Nama & Panjang Tangan \\
\hline 1 & Didin & 19 \\
\hline 2 & Arba'un & 18 \\
\hline 3 & Ika & 16 \\
\hline 4 & Sakinah & 17 \\
\hline 5 & Ardi & 16 \\
\hline
\end{tabular}

$\Sigma \mathrm{X}=86$

$(\Sigma X)^{2}=7396$

$\Sigma X^{2}=1486$

$\overline{\mathrm{X}} \quad=17,20$

$\mathrm{k} \quad=2$

$S \quad=0,05$

1. Kecukupan Data

Berikut ini adalah perhitungan kecukupan data pada pengukuran panjang tangan dalam posisi duduk tegak :

$\mathrm{N}^{\prime}=\left[\frac{\frac{\mathrm{k}}{\mathrm{s}} \sqrt{\mathrm{N} \cdot \Sigma \mathrm{X}^{2}-(\Sigma \mathrm{X})^{2}}}{\sum \mathrm{X}}\right]^{2}$ 


$$
\begin{aligned}
& =\left[\frac{\frac{2}{0,05} \sqrt{5 \cdot(1486)-7396}}{86}\right]^{2} \\
& =\left[\frac{40 \sqrt{7430-7396}}{86}\right]^{2} \\
& =\left[\frac{40 \sqrt{34}}{86}\right]^{2} \\
& =\left[\frac{40 \times 5,83}{86}\right]^{2} \\
& =\left[\frac{233,2}{86}\right]^{2} \\
& =[2,71]^{2}
\end{aligned}
$$

$=7,34$ (Data tidak cukup), $\mathrm{N}^{\prime}>\mathrm{n}$ maka perlu dilakukan pengambilan data lagi agar data tersebut cukup atau $\mathrm{N}=\mathrm{N}^{\prime}+\mathrm{n}$

2. Uji Keseragaman Data

Berikut ini adalah perhitungan standard deviasi pada pengukuran panjang tangan:

$$
\begin{aligned}
\sigma & =\sqrt{\frac{\sum\left(\mathrm{X}_{\mathrm{i}}-\overline{\mathrm{X}}\right)^{2}}{\mathrm{n}-1}} \\
= & \sqrt{\frac{(19-17,2)^{2}+(18-17,2)^{2}+(16-17,2)^{2}+(17-17,2)^{2}}{+(16-17,2)^{2}}} \frac{4-1}{4} \\
& =\sqrt{\frac{(1,8)^{2}+(0,8)^{2}+(-1,2)^{2}+(-0,2)^{2}+(-1,2)^{2}}{4}}
\end{aligned}
$$




$$
\begin{aligned}
& =\sqrt{\frac{3,24+0,64+1,44+0,04+1,44}{4}} \\
& =\sqrt{\frac{6,8}{4}} \\
& =\sqrt{1,7} \\
& =1,30
\end{aligned}
$$

Berikut ini adalah perhitungan BKA dan BKB pada pengukuran panjang tangan :

$$
\begin{aligned}
& \mathrm{BKA}=\overline{\mathrm{X}}+\mathrm{k} \times \sigma=17,20+(2 \times 1,30)=17,20+2,61=19,81 \\
& \mathrm{BKB}=\overline{\mathrm{X}}-\mathrm{k} \times \sigma=17,20-(2 \times 1,30)=17,20-2,61=14,59
\end{aligned}
$$

Sehingga dapat disimpulkan bahwa hasil uji keseragaman

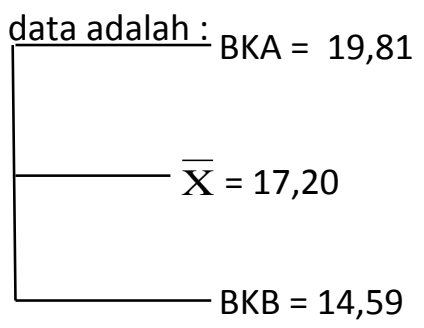

Berikut adalah gambar grafik dalam perhitungan antropometri pengukuran Panjang Tangan (PT). 


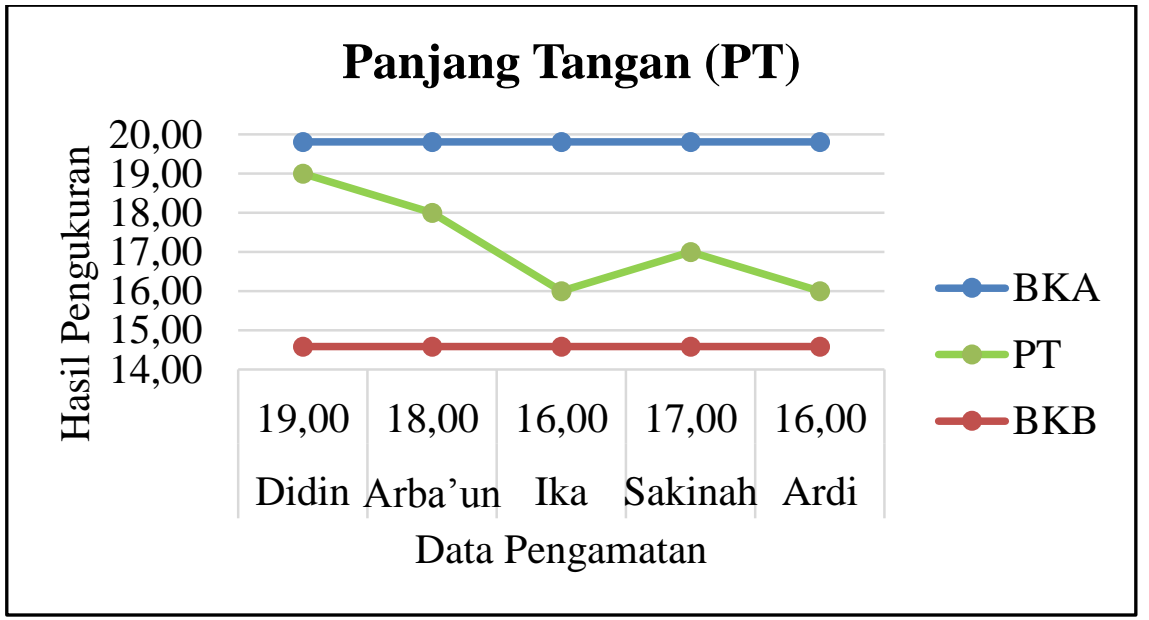

Gambar 4.4 Grafik Pengukuran Panjang Tangan (PT)

Dari hasil kesimpulan diatas dapat dikatakan bahwa tidak ada data ekstrim pada tabel pengamatan pengukuran panjang tangan.

3. Menghitung Persentil

$$
\begin{aligned}
\text { Persentil } 5 \%=\overline{\mathrm{X}}-(1,645 \times \sigma) \\
=17,20-(1,645 \times 1,30) \\
=17,20-2,14 \\
=15,06
\end{aligned}
$$

Persentil $50 \%=\bar{X}=17,20$

Persentil 95\% $=\overline{\mathrm{X}}+(1,645 \times \sigma)$

$$
\begin{aligned}
& =17,20+(1,645 \times 1,30) \\
& =17,20+2,14 \\
& =19,34
\end{aligned}
$$




\subsection{Analisis Data}

Dari hasil pengamatan terdapat empat sub kerja yang diamati yaitu Tinggi Duduk Tegak (TDT), Jangkauan Tangan Depan (JTD), Lebar Bahu (LB), Panjang Tangan (PT). Berikut ini adalah hasil dari analisa data yang dihasilkan dari pengamatan :

Dari hasil perhitungan pada pengukuran dimensi tinggi badan saat duduk tegak (TDT), diperoleh kecukupan data 1,03, standard devisiasi sebesar 1,90 dengan BKA sebesar 70,71 cm dan BKB sebesar $63,13 \mathrm{~cm}$, presentil ke-5 sebesar $63,80 \mathrm{~cm}$ persentil ke-50 sebesar $66,92 \mathrm{~cm}$, dan persentil ke-95 sebesar $70,04 \mathrm{~cm}$.

Dari pengolahan data proses pengukuran jangkauan tangan depan menunjukkan bahwa kecukupan data sebesar 1,92 kemudian standard deviasinya adalah 3,06, BKA sebesar 85,06 cm, BKB sebesar 72,82 cm, persentil ke-5 sebesar 73,91 cm, persentil ke-50 sebesar $78,94 \mathrm{~cm}$, persentil ke-95 sebesar 83,97 cm.

Dari pengolahan data proses pengukuran lebar bahu menunjukkan bahwa kecukupan data sebesar 0,80 kemudian standard deviasinya adalah 0,94, BKA sebesar $39,37 \mathrm{~cm}$, BKB sebesar $35,63 \mathrm{~cm}$, persentil ke-5 sebesar $35,96 \mathrm{~cm}$, persentil ke-50 sebesar $37,50 \mathrm{~cm}$, persentil ke-95 sebesar 39,04 cm.

Dari pengolahan data proses pengukuran panjang tangan menunjukkan bahwa kecukupan data 7,34 kemudian standard deviasinya adalah 1,30,BKA sebesar $19,81 \mathrm{~cm}$, BKB sebesar 14,59 cm, 
persentil ke-5 sebesar 15,06 cm,persentil ke-50 sebesar 17,20 cm,persentil ke-5 sebesar 19,34 cm.

\subsection{Kesimpulan}

Dari hasil perhitungan dimensi tubuh untuk merancang kursi yang ergonomis, maka kesimpulan yang didapat sebagai berikut:

1. Ada beberapa sumber variabilitas yang akan mengakibatkan perbedaan pada pengukuran dimensi tubuh manusia antar satu dengan lainnya, yaitu:

a. Umur.

b. Jenis Kelamin.

c. Suku Bangsa.

d. Postur Tubuh.

e. Cacat Tubuh

f. Tebal Tipis Pakaian

g. Kehamilan

2. Berikut adalah hasil pengukuran dimensi tubuh yang dilakukan berdasarkan perhitungan persentil.

a. Pada pengukuran Tinggi Duduk Tegak (TDT) didapatkan pengukuran pada persentil $5 \%$ adalah 63,80 , pada persentil $50 \%$ adalah 66,92 dan pada persentil 95\% adalah 70,04.

b. Pada pengukuran Jangkauan Tangan Depan (JTD) didapatkan pengukuran pada persentil 5\% adalah 73,91, 
pada persentil $50 \%$ adalah 78,94 dan pada persentil $95 \%$ adalah 83,90.

c. Pada pengukuran Lebar Bahu (LB) didapatkan pengukuran pada persentil $5 \%$ adalah 35,96 , pada persentil $50 \%$ adalah 37,5 dan pada persentil 95\% adalah 39,04.

d. Pada pengukuran Panjang Tangan (PT) didapatkan pengukuran pada persentil $5 \%$ adalah 15,06 , pada persentil $50 \%$ adalah 17,20 dan pada persentil $95 \%$ adalah 19,34.

3. Dari hasil praktikum yang dilakukan, kita dapat merancang produk kursi kuliah yang ergonomis sesuai dengan nilai persentil yang didapat menggunakan pengukuran dimensi tubuh. 


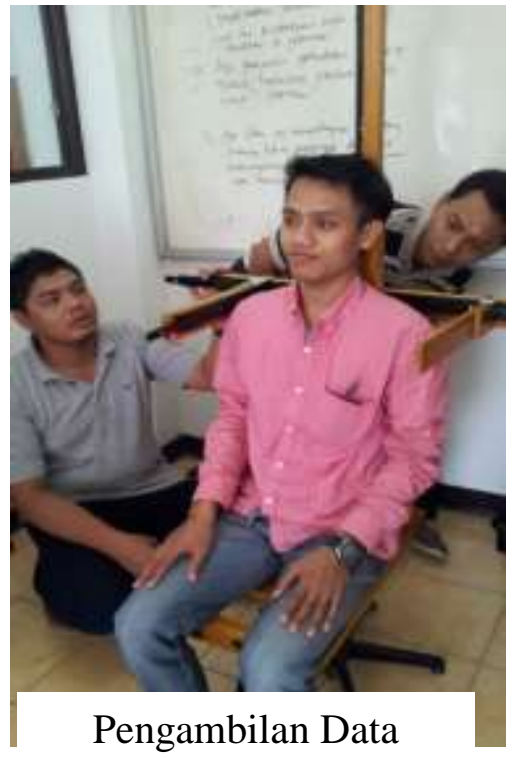

Lebar Bahu (LB)

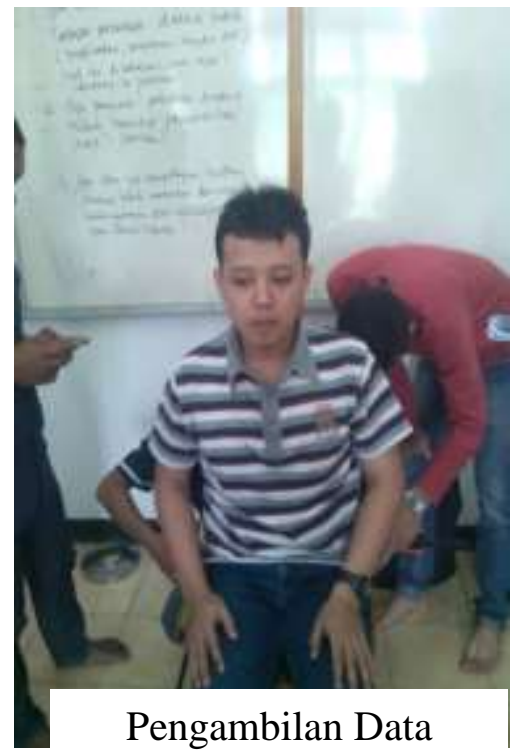

Panjang Tangan (PT)

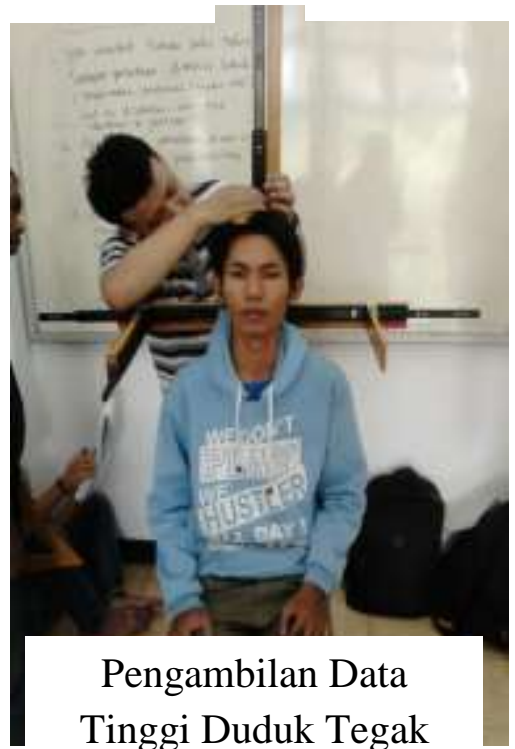

(TDT) 


\section{BAB. 13}

\section{PENERAPAN STUDY EKONOMI GERAKAN (MICROMOTION STUDY) GUNA MENGEFISIENKAN GERAKAN KERJA}

\subsection{Studi Gerakan Untuk Menganalisa Metode Kerja}

Menurut Wignjosoebroto (2008), studi gerakan adalah studi tentang gerakan-gerakan yang dilakukan pekerja untuk menyelesaikan pekerjaannya. Dengan studi ini diperoleh gerakangerakan standard untuk penyelesaian suatu pekerjaan, yaitu rangkaian gerakan-gerakan yang efektif dan efisien. Untuk memperoleh hal itu maka perlu diperlukan perhatian terlebih dahulu kondisi pekerjaan yang ada yaitu kondisi pekerjaan yang memungkinkan dilakukan gerakan-gerakan kerja yang ergonomis.

Menurut Widodo (2013), efektifitas sebuah system produksi tidak hanya dilihat dari metode kerja, namun juga dari keseimbangan lintasan produksi. Ditemukan metode kerja terbaik dari micromotion study maka waktu siklus setiap stasiun kerja akan optimal sehingga tidak lagi terjadi penumpukan barang yang menunggu diproses pada stasiun kerja.

Studi gerakan umumnya diklasifikasikan ke dalam dua macam studi, yaitu visual motion study dan micromotion study umumnya lebih sering diaplikasikan karena dianggap jauh lebih ekonomis. Disini 
hanya sekedar dilakukan pengamatan secara visual terhadap operasi kerja yang berlangsung dan kemudian dibuat suatu peta yang dikenal dengan operator process chart.

\subsection{Gerakan Fundamental Untuk Pelaksanaan Kerja Manual}

Menurut Sitohang (2015), Untuk mempermudah penganalisaan terhadap gerakan-gerakan yang akan dipelajari perlu dikenal terlebih dahulu gerakan-gerakan dasar yang membentuk kerja tersebut. Guna melaksanakan maksud ini, maka Frank dan Lillian Gilberth telah menciptakan simbol atau kode dari gerakangerakan dasar kerja yang dikenal dengan nama therblig (dieja dari nama Gilberth secara terbalik). Disini menguraikan gerakan-gerakan kerja kedalam 17 gerakan dasar therblig. Secara garis besar masingmasing therblig tersebut dapat didefinisikan sebagai berikut:

Tabel 2.1 Macam-macam Elemen Gerakan Therbligs

\begin{tabular}{|c|l|c|c|c|}
\hline No & \multicolumn{1}{|c|}{ Nama Therblig } & $\begin{array}{c}\text { Lambang } \\
\text { Huruf }\end{array}$ & $\begin{array}{c}\text { Kode } \\
\text { Warna }\end{array}$ & Lambang Gambar \\
\hline 1 & Mencari (Search) & Sh & Black \\
\hline 2 & Memilih (Select) & SI & Gray Light \\
\hline 4 & $\begin{array}{l}\text { Memegang } \\
\text { (Grasp) }\end{array}$ & $\mathrm{G}$ & Lake Red \\
\hline 5 & $\begin{array}{l}\text { Menjangkau } \\
\text { (Transport Empy) } \\
\text { (Transport beban }\end{array}$ & $\mathrm{TE}$ & $\begin{array}{l}\text { Olive } \\
\text { Green }\end{array}$ \\
\hline
\end{tabular}




\begin{tabular}{|c|c|c|c|c|}
\hline & Loaded) & & & \\
\hline 6 & Memegang (Hold) & $\mathrm{H}$ & $\begin{array}{l}\text { Gold } \\
\text { Ochre }\end{array}$ & \\
\hline 7 & $\begin{array}{l}\text { Melepas (Release } \\
\text { Load) }\end{array}$ & $\mathrm{RL}$ & $\begin{array}{c}\text { Carmine } \\
\text { Red }\end{array}$ & \\
\hline 8 & $\begin{array}{l}\text { Mengarahkan } \\
\text { (Position) }\end{array}$ & $P$ & Blue & \\
\hline 9 & $\begin{array}{l}\text { Mengarahkan } \\
\text { awal (Pre } \\
\text { Position) }\end{array}$ & PP & Sky Blue & \\
\hline 10 & $\begin{array}{l}\text { Memeriksa } \\
\text { (Inspection) }\end{array}$ & 1 & $\begin{array}{l}\text { Burn } \\
\text { Ochre }\end{array}$ & \\
\hline 11 & $\begin{array}{l}\text { Merakit } \\
\text { (Assemble) }\end{array}$ & $A$ & $\begin{array}{l}\text { Violet, } \\
\text { Heavy }\end{array}$ & \\
\hline 12 & $\begin{array}{l}\text { Mengurai rakit } \\
\text { (Disassmebly) }\end{array}$ & DA & Violet & \\
\hline 13 & Memakai (Use) & $U$ & Purple & \\
\hline 14 & $\begin{array}{l}\text { Keterlambatan } \\
\text { yang tak } \\
\text { terhindarkan } \\
\text { (Unavoidable } \\
\text { Delay) }\end{array}$ & UD & $\begin{array}{l}\text { Yellow } \\
\text { Ochre }\end{array}$ & \\
\hline 15 & $\begin{array}{l}\text { Keterlambatan } \\
\text { yang dapat } \\
\text { dihindarkan } \\
\text { (Avoidable Delay) }\end{array}$ & $A D$ & $\begin{array}{l}\text { Lemon } \\
\text { Yellow }\end{array}$ & \\
\hline 16 & Merencana (Plan) & $\mathrm{Pn}$ & Brown & \\
\hline
\end{tabular}




\begin{tabular}{|c|l|c|c|c|}
\hline 17 & $\begin{array}{l}\text { Istirahat } \\
\text { menghilangkan } \\
\text { lelah (Rest) }\end{array}$ & $\mathrm{R}$ & Orange
\end{tabular}

Sumber: Setiawan, (2013)

\subsection{Peta Tangan Kiri dan Tangan Kanan}

Menurut Wignjosoebroto (2008), peta tangan kiri dan tangan kanan adalah peta kerja setempat yang bermanfaat untuk menganalisa gerakan tangan manusia didalam melakukan pekerjaanpekerjaan yang bersifat manual. Peta ini akan menggambarkan semua gerakan ataupun delay yang terjadi yang dilakukan oleh tangan kanan maupun tangan kiri secara mendetail dengan elemenelemen therblig yang membentuk gerakan tersebut. Dengan menganalisa detail gerakan yang terjadi maka langkah-langkah perbaikan bisa diusulkan.

Pembuatan peta kerja tangan kiri dan tangan kanan baru terasa bermanfaat apabila gerakan yang gerakan yang dianalisa tersebut terjadi berulang-ulang dan dilakukan secara manual. Dari analisa yang dibuat maka pola gerakan tangan yang dianggap tidak efisien dan bertentangan dengan prinsip-prinsip ekonomi gerakan bisa diusulkan untuk diperbaiki. Demikian pula akan diharapkan terjadi keseimbangan gerakan yang dilakukan oleh tangan kiri dan tangan kanan, sehingga siklus kerja akan berlangsung dengan lancar.

Meskipun Franks dan Lillian Gilberth telah menyatakan bahwa gerakan-gerakan kerja manusia dilaksanakan dengan mengikuti 17 
elemen dasar therblig danatau kombinasi dari elemen-elemen therblig tersebut, akan tetapi dalam membuat peta kerja tangan kiri dan tangan kanan akan lebih efektif jika hanya 8 elemen therblig berikut ini yang digunakan, yaitu: Reach (RE), Grasp (G), Move (M), Position (P), Use (U), Release (RL), Delay (D) dan Hold (H).

Setelah semua gerakan tangan kanan dan tangan kiri selesai dipetakan untuk satu siklus kerja maka satu kesimpulan umum perlu dibuat pada bagian terbawah dari peta kerja ini, yaitu yang menunjukkan total siklus waktu yang dibutuhkan untuk menyelesaikan kerja, jumlah produk siklus kerja, dan total waktu penyelesaian kerja perunit produk. Jumah total waktu kerja tangan kanan dan tangan kiri haruslah sama.

\subsection{Data Hasil Pengamatan}

Pada bab ini akan menjelaskan mengenai data hasil pengamatan pada saat merakit leggomobil mainan dari praktikum perancangan sistem kerja dan ergonomi modul micromotion study. Terlihat pada tabel 3.1 dan tabel 3.2.

\subsection{Data Hasil Pengamatan Material Dengan Peletakan Tidak Beraturan}

Adapun data hasil pengamatan material dengan peletakan tidak beraturan tersebut dapat dilihat pada tabel 3.1 sebagai berikut :

Tabel 3.1 Data Hasil Pengamatan Material Dengan Peletakan Tidak Beraturan 


\begin{tabular}{|c|c|c|c|c|c|c|c|c|c|c|}
\hline \multicolumn{11}{|c|}{ Peta Tangan Kiri Dan Tangan Kanan } \\
\hline \multicolumn{2}{|c|}{$\begin{array}{l}\text { Pekerjaan } \\
\text { Nomor Peta } \\
\text { Departemen } \\
\end{array}$} & \multicolumn{4}{|c|}{$\begin{array}{l}\text { : Merakit Lego Mobil } \\
: 01122018 \\
\text { :Teknik Industri }\end{array}$} & \multicolumn{3}{|c|}{ Di Periksa Oleh } & \multicolumn{2}{|c|}{ : Boy Isma Putra, ST., MM } \\
\hline No. & Tangan Kiri & $\begin{array}{l}\text { Waktu } \\
\text { (detik) }\end{array}$ & $\begin{array}{c}\text { Lambang } \\
\text { Huruf }\end{array}$ & $\begin{array}{c}\text { Lambang } \\
\text { Gambar }\end{array}$ & $\begin{array}{c}\text { Lambang } \\
\text { Warna }\end{array}$ & $\begin{array}{c}\text { Lambang } \\
\text { Warna }\end{array}$ & $\begin{array}{c}\text { Lambang } \\
\text { Gambar }\end{array}$ & $\begin{array}{c}\text { Lambang } \\
\text { Huruf }\end{array}$ & $\begin{array}{l}\text { Waktu } \\
\text { (detik) }\end{array}$ & Tangan Kanan \\
\hline 1 & Memegang Bagian Dasar Rangka & 2 & $\mathrm{G}$ & $\Omega$ & Lake Red & Gray & $\longrightarrow$ & SI & 2 & Memilih Bagian Bawah \\
\hline 2 & Memegang Bagian Dasar Rangka & 2 & $\mathrm{G}$ & $\Omega$ & Lake Red & Violet Heavy & 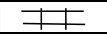 & $\mathrm{A}$ & 2 & Merakit Bagian Bawah \\
\hline 3 & Memegang Bagian Dasar Rangka & 1 & $\mathrm{G}$ & $\Omega$ & Lake Red & Black & 80 & $\mathrm{Sh}$ & 1 & Mencari Bagian Bawah \\
\hline 4 & Memegang Bagian Dasar Rangka & 1 & $\mathrm{G}$ & $\Omega$ & Lake Red & Gray & $\longrightarrow$ & SI & 1 & Memilih Bagian Bawah \\
\hline 5 & Memegang Bagian Dasar Rangka & 2 & $\mathrm{G}$ & $\Omega$ & Lake Red & Violet Heavy & $\mp$ & A & 2 & Merakit Bagian Bawah \\
\hline 6 & Memegang Bagian Dasar Rangka & 3 & $\mathrm{G}$ & $\Omega$ & Lake Red & Gray & $\longrightarrow$ & SI & 3 & Memilih Bagian Bawah \\
\hline 7 & Memegang Bagian Dasar Rangka & 4 & $\mathrm{G}$ & $\Omega$ & Lake Red & Brown & $\beta$ & $\mathrm{Pn}$ & 4 & Merencanakan Rakitan Bagian Bawah \\
\hline 8 & Memegang Bagian Dasar Rangka & 1 & $\mathrm{G}$ & $\Omega$ & Lake Red & Violet Heavy & $\mp$ & $\mathrm{A}$ & 1 & Merakit Bagian Bawah \\
\hline 9 & Memegang Bagian Dasar Rangka & 2 & $\mathrm{G}$ & $\Omega$ & Lake Red & Gray & $\longrightarrow$ & SI & 2 & Memilih Bagian Bawah \\
\hline 10 & Memegang Bagian Dasar Rangka & 2 & $\mathrm{G}$ & $\Omega$ & Lake Red & Violet Heavy & \pm & $\mathrm{A}$ & 2 & Merakit Bagian Bawah \\
\hline 11 & Memegang Bagian Dasar Rangka & 1 & $\mathrm{G}$ & $\Omega$ & Lake Red & Gray & $\longrightarrow$ & SI & 1 & Memilih Bagian Bawah \\
\hline 12 & Memegang Bagian Dasar Rangka & 2 & $\mathrm{G}$ & $\Omega$ & Lake Red & Violet Heavy & $\mp$ & $\mathrm{A}$ & 2 & Merakit Bagian Bawah \\
\hline 13 & Memegang Bagian Dasar Rangka & 3 & $\mathrm{G}$ & $\Omega$ & Lake Red & Gray & $\longrightarrow$ & SI & 3 & Memilih Bagian Bawah \\
\hline 14 & Memegang Bagian Dasar Rangka & 2 & $\mathrm{G}$ & $\Omega$ & Lake Red & Violet Heavy & 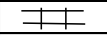 & $\mathrm{A}$ & 2 & Merakit Bagian Bawah \\
\hline 15 & Memegang Rangka & 3 & $\mathrm{G}$ & $\Omega$ & Lake Red & Brown & $\beta$ & $\mathrm{Pn}$ & 3 & Merencanakan Bagian Bawah \\
\hline 16 & Memegang Rangka & 2 & $\mathrm{G}$ & $\Omega$ & Lake Red & Gray & $\longrightarrow$ & SI & 2 & Memilih Bagian Bawah \\
\hline 17 & Memegang Bagian Depan & 1 & $\mathrm{G}$ & $\Omega$ & Lake Red & Gray & $\longrightarrow$ & $\mathrm{SI}$ & 1 & Memilih Bagian Depan \\
\hline 18 & Memegang Bagian Depan & 4 & $\mathrm{G}$ & $\Omega$ & Lake Red & Brown & $\beta$ & $\mathrm{Pn}$ & 4 & Merencanakan Rakitan \\
\hline 19 & Memegang Bagian Depan & 3 & $\mathrm{G}$ & $\Omega$ & Lake Red & Violet Heavy & $\mp 1$ & $\mathrm{~A}$ & 3 & Merakit Bagian Depan \\
\hline 20 & Memegang Bagian Depan & 1 & G & $\Omega$ & Lake Red & Gray & $\longrightarrow$ & SI & 1 & Memilih Bagian Depan \\
\hline 21 & Memegang Bagian Depan & 2 & $\mathrm{G}$ & $\Omega$ & Lake Red & Violet Heavy & \pm 1 & $\mathrm{~A}$ & 2 & Merakit Bagian Depan \\
\hline 22 & Memegang Bagian Depan & 1 & $\mathrm{G}$ & $\Omega$ & Lake Red & Gray & $\longrightarrow$ & SI & 1 & Memilih Bagian Depan \\
\hline
\end{tabular}


Tabel 3.1 Data Hasil Pengamatan Material Dengan Peletakan Tidak Beraturan (Lanjutan)

\begin{tabular}{|c|c|c|c|c|c|c|c|c|c|c|}
\hline \multicolumn{11}{|c|}{ Peta Tangan Kiri Dan Tangan Kanan } \\
\hline \multirow{3}{*}{\multicolumn{2}{|c|}{$\begin{array}{l}\text { Pekerjaan } \\
\text { Nomor Peta } \\
\text { Departemen } \\
\end{array}$}} & \multirow{3}{*}{\multicolumn{4}{|c|}{$\begin{array}{l}\text { : Merakit Lego Mobil } \\
: 01122018 \\
: \text { Teknik Industri }\end{array}$}} & \multirow{3}{*}{\multicolumn{3}{|c|}{ Di Periksa Oleh }} & \multirow{3}{*}{\multicolumn{2}{|c|}{ : Boy Isma Putra, ST., MM }} \\
\hline & & & & & & & & & & \\
\hline & & & & & & & & & & \\
\hline No. & Tangan Kiri & $\begin{array}{l}\text { Waktu } \\
\text { (detik) }\end{array}$ & \begin{tabular}{|c} 
Lambang \\
Huruf
\end{tabular} & $\begin{array}{c}\text { Lambang } \\
\text { Gambar } \\
\end{array}$ & $\begin{array}{c}\text { Lambang } \\
\text { Warna }\end{array}$ & $\begin{array}{c}\begin{array}{c}\text { Lambang } \\
\text { Warna }\end{array} \\
\end{array}$ & $\begin{array}{c}\text { Lambang } \\
\text { Gambar }\end{array}$ & $\begin{array}{c}\text { Lambang } \\
\text { Huruf }\end{array}$ & $\begin{array}{l}\text { Waktu } \\
\text { (detik) }\end{array}$ & Tangan Kanan \\
\hline 23 & Memegang Bagian Depan & 3 & $\mathrm{G}$ & $\Omega$ & Lake Red & Violet Heavy & \# & $\mathrm{A}$ & 3 & Merakit Bagian Depan \\
\hline 24 & Memegang Bagian Depan & 1 & $\mathrm{G}$ & $\Omega$ & Lake Red & Gray & $\longrightarrow$ & SI & 1 & Memilih Bagian Depan \\
\hline 25 & Memegang Bagian Depan & 5 & $\mathrm{G}$ & $\Omega$ & Lake Red & Violet Heavy & $\mp 1$ & A & 5 & Merakit Bagian Depan \\
\hline 26 & Memegang Bagian Depan & 2 & $\mathrm{G}$ & $\Omega$ & Lake Red & Gray & $\longrightarrow$ & SI & 2 & Memilih Bagian Depan \\
\hline 27 & Memegang Bagian Depan & 1 & $\mathrm{G}$ & $\Omega$ & Lake Red & Orange & $\mathrm{E}$ & $\mathrm{R}$ & 1 & Istirahat \\
\hline 28 & Mengambil Bagian Rangka Bawah & 3 & RE & $\gamma^{2}$ & Olive Green & Lake Red & $\Omega$ & $\mathrm{G}$ & 3 & Memegang Bagian Depan \\
\hline 29 & Memeriksa Rakitan Bagian Depan & 2 & I & 9 & Burn Ochre & Burn Ochre & 9 & I & 2 & Memeriksa Rakitan Bagian Depan \\
\hline 30 & Memegang Bagian Rangka Bawah & 3 & $\mathrm{G}$ & $\Omega$ & Lake Red & Violet Heavy & 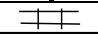 & $\mathrm{A}$ & 3 & Merakit Bagian Depan \\
\hline 31 & Menaruh Rangka Bawah & 2 & RL & 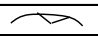 & Carmine Red & Gray & $\longrightarrow$ & SI & 2 & Memilih Bagian Samping Kanan \\
\hline 32 & Memegang Bagian Samping Kanan & 2 & $\mathrm{G}$ & $\Omega$ & Lake Red & Gray & $\longrightarrow$ & SI & 2 & Memilih Bagian Samping Kanan \\
\hline 33 & Memegang Bagian Samping Kanan & 2 & $\mathrm{G}$ & $\Omega$ & Lake Red & Violet Heavy & $\#$ & A & 2 & Merakit Bagian Samping Kanan \\
\hline 34 & Menaruh Bagian Samping Kanan & 2 & $\mathrm{RL}$ & $\longrightarrow$ & Carmine Red & Gray & $\longrightarrow$ & SI & 2 & Memilih Bagian Samping Kiri \\
\hline 35 & Menaruh Bagian Samping Kiri & 2 & RL & 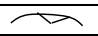 & Carmine Red & Violet Heavy & \pm 1 & A & 2 & Merakit Bagian Samping Kiri \\
\hline 36 & Mengarahkan Bagian Samping Kanan & 2 & $\mathrm{P}$ & 9 & Blue & Blue & 9 & $\mathrm{P}$ & 2 & Mengarahkan Bagian Samping Kiri \\
\hline 37 & Mengambil Bagian Rangka & 2 & $\mathrm{RE}$ & $\gamma^{2}$ & Olive Green & Olive Green & $\gamma^{2}$ & $\mathrm{RE}$ & 2 & Mengambil Bagian Samping Kanan \\
\hline 38 & Memegang Bagian Rangka & 2 & $\mathrm{G}$ & $\Omega$ & Lake Red & Violet Heavy & $\mp 1$ & $\mathrm{~A}$ & 2 & Merakit Bagian Samping Kanan \\
\hline 39 & Memegang Bagian Rangka & 1 & $\mathrm{G}$ & $\Omega$ & Lake Red & Gray & $\longrightarrow$ & SI & 1 & Memilih Bagian Samping Kiri \\
\hline 40 & Memegang Bagian Rangka & 3 & $\mathrm{G}$ & $\Omega$ & Lake Red & Violet Heavy & $\# 1$ & $\mathrm{~A}$ & 3 & Merakit Bagian Samping Kiri \\
\hline 41 & Menaruh Rangka & 2 & RL & 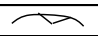 & Carmine Red & Orange & $\mathrm{E}$ & $\mathrm{R}$ & 2 & Istirahat \\
\hline 42 & Istirahat & 2 & $\mathrm{R}$ & $\mathrm{E}$ & Orange & Brown & $\beta$ & $\mathrm{Pn}$ & 2 & Merencanakan (Melihat Panduan) \\
\hline 43 & Mengarahkan Bagian Samping Kiri & 1 & $\mathrm{P}$ & 9 & Blue & Black & 5 & Sh & 1 & Mencari Komponen \\
\hline 44 & Mengarahkan Bagian Samping Kiri & 1 & $\mathrm{P}$ & 9 & Blue & Orange & $\mathrm{E}$ & $\mathrm{R}$ & 1 & Istirahat \\
\hline 45 & Memegang Bagian Belakang & 2 & $\mathrm{G}$ & $\Omega$ & Lake Red & Violet & +1 & DA & 2 & Mengurai Rakitan Bagian Belakang \\
\hline 46 & Istirahat & 2 & $\mathrm{R}$ & $\mathrm{E}$ & Orange & Carmine Red & 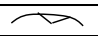 & RL & 2 & Menaruh Bagian Belakang \\
\hline 47 & Mencari Komponen & 1 & Sh & 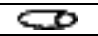 & Black & Black & 0 & Sh & 1 & Mencari Komponen \\
\hline
\end{tabular}




\begin{tabular}{|c|c|c|c|c|c|c|c|c|c|c|}
\hline \multicolumn{11}{|c|}{ Peta Tangan Kiri Dan Tangan Kanan } \\
\hline \multirow{3}{*}{\multicolumn{2}{|c|}{$\begin{array}{l}\text { Pekerjaan } \\
\text { Nomor Peta } \\
\text { Departemen }\end{array}$}} & \multirow{3}{*}{\multicolumn{4}{|c|}{$\begin{array}{l}\text { : Merakit Lego Mobil } \\
: 01122018 \\
: \text { Teknik Industri }\end{array}$}} & \multirow{3}{*}{\multicolumn{3}{|c|}{ Di Periksa Oleh }} & \multirow{3}{*}{\multicolumn{2}{|c|}{ : Boy Isma Putra, ST., MM }} \\
\hline & & & & & & & & & & \\
\hline & & & & & & & & & & \\
\hline No. & Tangan Kiri & $\begin{array}{l}\text { Waktu } \\
\text { (detik) }\end{array}$ & \begin{tabular}{|c} 
Lambang \\
Huruf
\end{tabular} & $\begin{array}{c}\text { Lambang } \\
\text { Gambar }\end{array}$ & $\begin{array}{c}\text { Lambang } \\
\text { Warna }\end{array}$ & $\begin{array}{c}\text { Lambang } \\
\text { Warna }\end{array}$ & $\begin{array}{c}\text { Lambang } \\
\text { Gambar }\end{array}$ & $\begin{array}{c}\text { Lambang } \\
\text { Huruf }\end{array}$ & $\begin{array}{l}\text { Waktu } \\
\text { (detik) }\end{array}$ & Tangan Kanan \\
\hline 48 & Memilih Bagian Belakang & 3 & \begin{tabular}{|l|} 
SI \\
\end{tabular} & $\longrightarrow$ & Gray & Orange & $\overline{\mathrm{E}}$ & $\mathrm{R}$ & 3 & Istirahat \\
\hline 49 & Memegang Bagian Belakang & 3 & $\mathrm{G}$ & $\Omega$ & Lake Red & Gray & $\longrightarrow$ & SI & 3 & Memilih Bagian Belakang \\
\hline 50 & Memegang Bagian Belakang & 2 & $\mathrm{G}$ & $\Omega$ & Lake Red & Gray & $\longrightarrow$ & SI & 2 & Memilih Bagian Belakang \\
\hline 51 & Memegang Bagian Belakang & 2 & $\mathrm{G}$ & $\Omega$ & Lake Red & Violet Heavy & † & $\mathrm{A}$ & 2 & Merakit Bagian Belakang \\
\hline 52 & Memegang Bagian Belakang & 4 & $\mathrm{G}$ & $\Omega$ & Lake Red & Brown & $\beta$ & $\mathrm{Pn}$ & 4 & Merencanakan Bagian Belakang \\
\hline 53 & Memegang Bagian Belakang & 2 & $\mathrm{G}$ & $\Omega$ & Lake Red & Violet Heavy & 71 & $\mathrm{~A}$ & 2 & Merakit Bagian Belakang \\
\hline 54 & Memegang Bagian Belakang & 1 & $\mathrm{G}$ & $\Omega$ & Lake Red & Gray & $\longrightarrow$ & SI & 1 & Memilih Bagian Belakang \\
\hline 55 & Memegang Bagian Belakang & 3 & $\mathrm{G}$ & $\Omega$ & Lake Red & Violet Heavy & 71 & $\mathrm{~A}$ & 3 & Merakit Bagian Belakang \\
\hline 56 & Mengambil Rangka & 1 & $\mathrm{RE}$ & $v^{\prime}$ & Olive Green & Lake Red & $\Omega$ & $\mathrm{G}$ & 1 & Memegang Bagian Belakang \\
\hline 57 & Memegang Rangka & 1 & $\mathrm{G}$ & $\Omega$ & Lake Red & Gray & $\longrightarrow$ & $\mathrm{SI}$ & 1 & Memilih Bagian Tengah \\
\hline 58 & Memegang Rangka & 2 & $\mathrm{G}$ & $\Omega$ & Lake Red & Carmine Red & $\longrightarrow$ & RL & 2 & Menaruh Bagian Belakang \\
\hline 59 & Memegang Rangka & 3 & $\mathrm{G}$ & $\Omega$ & Lake Red & Brown & $\beta$ & $\mathrm{Pn}$ & 3 & Merencanakan Bagian Tengah \\
\hline 60 & Mengambil Rangka & 3 & RE & $V^{2}$ & Olive Green & Violet Heavy & 71 & $\mathrm{~A}$ & 3 & Merakit Bagian Tengah \\
\hline 61 & Mengambil Bagian Depan & 2 & RE & $v^{2}$ & Olive Green & Lake Red & $\Omega$ & $\mathrm{G}$ & 2 & Memegang Rangka \\
\hline 62 & Merakit Bagian Depan & 5 & $\mathrm{~A}$ & 7 & Violet Heavy & Lake Red & $\Omega$ & $\mathrm{G}$ & 5 & Memegang Rangka \\
\hline 63 & Memegang Rangka & 1 & $\mathrm{G}$ & $\Omega$ & Lake Red & Gray & $\longrightarrow$ & SI & 1 & Memilih Bagian Depan \\
\hline 64 & Memegang Rangka & 2 & $\mathrm{G}$ & $\Omega$ & Lake Red & Violet Heavy & 11 & $\mathrm{~A}$ & 2 & Merakit Bagian Depan \\
\hline 65 & Memegang Rangka & 3 & $\mathrm{G}$ & $\Omega$ & Lake Red & Gray & $\longrightarrow$ & SI & 3 & Memilih Bagian Depan \\
\hline 66 & Memegang Rangka & 3 & $\mathrm{G}$ & $\Omega$ & Lake Red & Violet Heavy & 11 & $\mathrm{~A}$ & 3 & Merakit Bagian Belakang \\
\hline 67 & Memegang Rangka & 1 & $\mathrm{G}$ & $\Omega$ & Lake Red & Gray & $\longrightarrow$ & SI & 1 & Memilih Bagian Belakang \\
\hline 68 & Memegang Rangka & 2 & $\mathrm{G}$ & $\Omega$ & Lake Red & Violet Heavy & 11 & $\mathrm{~A}$ & 2 & Merakit Bagian Belakang \\
\hline 69 & Memegang Rangka & 3 & $\mathrm{G}$ & $\Omega$ & Lake Red & Gray & $\longrightarrow$ & SI & 3 & Memilih Bagian Belakang \\
\hline 70 & Memegang Rangka & 2 & $\mathrm{G}$ & $\Omega$ & Lake Red & Violet Heavy & I1 & $\mathrm{A}$ & 2 & Merakit Bagian Belakang \\
\hline 71 & Memegang Rangka & 2 & $\mathrm{G}$ & $\Omega$ & Lake Red & Gray & $\longrightarrow$ & SI & 2 & Memilih Bagian Belakang \\
\hline 72 & Memegang Rangka & 2 & $\mathrm{G}$ & $\Omega$ & Lake Red & Violet Heavy & 71 & $\mathrm{~A}$ & 2 & Merakit Bagian Belakang \\
\hline
\end{tabular}




\begin{tabular}{|c|c|c|c|c|c|c|c|c|c|c|}
\hline \multicolumn{11}{|c|}{ Peta Tangan Kiri Dan Tangan Kanan } \\
\hline \multirow{3}{*}{\multicolumn{2}{|c|}{$\begin{array}{l}\text { Pekerjaan } \\
\text { Nomor Peta } \\
\text { Departemen }\end{array}$}} & \multirow{3}{*}{\multicolumn{4}{|c|}{$\begin{array}{l}\text { : Merakit Lego Mobil } \\
01122018 \\
\text { :Teknik Industri }\end{array}$}} & \multirow{3}{*}{\multicolumn{3}{|c|}{ Di Periksa Oleh }} & \multirow{3}{*}{\multicolumn{2}{|c|}{ : Boy Isma Putra, ST., MM }} \\
\hline & & & & & & & & & & \\
\hline & & & & & & & & & & \\
\hline No. & Tangan Kiri & $\begin{array}{l}\text { Waktu } \\
\text { (detik) }\end{array}$ & $\begin{array}{c}\text { Lambang } \\
\text { Huruf }\end{array}$ & $\begin{array}{c}\text { Lambang } \\
\text { Gambar }\end{array}$ & $\begin{array}{c}\text { Lambang } \\
\text { Warna }\end{array}$ & $\begin{array}{c}\text { Lambang } \\
\text { Warna }\end{array}$ & $\begin{array}{c}\text { Lambang } \\
\text { Gambar }\end{array}$ & $\begin{array}{c}\text { Lambang } \\
\text { Huruf }\end{array}$ & $\begin{array}{l}\text { Waktu } \\
\text { (detik) }\end{array}$ & Tangan Kanan \\
\hline 73 & Menaruh Rangka & 3 & RL & 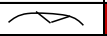 & Carmine Red & Black & 5 & $\mathrm{Sh}$ & 3 & Mencari Bagian Belakang \\
\hline 74 & Istirahat & 3 & $\mathrm{R}$ & $\mathrm{E}$ & Orange & Black & $\Rightarrow$ & Sh & 3 & Mencari Bagian Belakang \\
\hline 75 & Istirahat & 2 & $\mathrm{R}$ & $\overline{\mathrm{E}}$ & Orange & Gray & $\longrightarrow$ & SI & 2 & Memilih Bagian Belakang \\
\hline 76 & Memegang Bagian Belakang & 1 & $\mathrm{G}$ & $\Omega$ & Lake Red & Gray & $\longrightarrow$ & SI & 1 & Memilih Bagian Belakang \\
\hline 77 & Memegang Bagian Belakang & 6 & $\mathrm{G}$ & $\Omega$ & Lake Red & Violet Heavy & +1 & $\mathrm{A}$ & 6 & Merakit Bagian Belakang \\
\hline 78 & Mengambil Rangka & 2 & RE & $v^{\prime}$ & Olive Green & Lake Red & $\Omega$ & $\mathrm{G}$ & 2 & Memegang Bagian Belakang \\
\hline 79 & Memegang Rangka & 4 & $\mathrm{G}$ & $\Omega$ & Lake Red & Violet Heavy & 71 & $\mathrm{~A}$ & 4 & Merakit Bagian Belakang \\
\hline 80 & Merencanakkan Bagian Belakang & 11 & $\mathrm{Pn}$ & $\beta$ & Brown & Brown & $\beta$ & $\mathrm{Pn}$ & 11 & Merencanakkan Bagian Belakang \\
\hline 81 & Memegang Rangka & 2 & $\mathrm{G}$ & $\Omega$ & Lake Red & Violet & +1 & $\mathrm{DA}$ & 2 & Mengurai Rakitan Bagian Belakang \\
\hline 82 & Memegang Rangka & 1 & $\mathrm{G}$ & $\Omega$ & Lake Red & Violet Heavy & $\mp 1$ & $\mathrm{~A}$ & 1 & Merakit Bagian Belakang \\
\hline 83 & Memegang Rangka & 3 & $\mathrm{G}$ & $\Omega$ & Lake Red & Violet Heavy & $\mp 1$ & A & 3 & Merakit Bagian Belakang \\
\hline 84 & Memegang Rangka & 4 & G & $\Omega$ & Lake Red & Gray & $\longrightarrow$ & SI & 4 & Memilih Bagian Tengah \\
\hline 85 & Memegang Rangka & 4 & $\mathrm{G}$ & $\Omega$ & Lake Red & Violet Heavy & \pm 1 & $\mathrm{~A}$ & 4 & Merakit Bagian Tengah \\
\hline 86 & Memegang Rangka & 5 & $\mathrm{G}$ & $\Omega$ & Lake Red & Black & 0 & $\mathrm{Sh}$ & 5 & Mencari Komponen \\
\hline 87 & Memegang Rangka & 3 & $\mathrm{G}$ & $\Omega$ & Lake Red & Gray & $\longrightarrow$ & SI & 3 & Memilih Bagian Tengah \\
\hline 88 & Memegang Rangka & 3 & $\mathrm{G}$ & $\Omega$ & Lake Red & Violet Heavy & +1 & $\mathrm{~A}$ & 3 & Merakit Bagian Tengah \\
\hline 89 & Memegang Rangka & 2 & $\mathrm{G}$ & $\Omega$ & Lake Red & Gray & $\longrightarrow$ & SI & 2 & Memilih Bagian Tengah \\
\hline 90 & Memegang Rangka & 2 & $\mathrm{G}$ & $\Omega$ & Lake Red & \begin{tabular}{|l|} 
Violet Heavy \\
\end{tabular} & +1 & $\mathrm{~A}$ & 2 & Merakit Bagian Tengah \\
\hline 91 & Memegang Rangka & 2 & $\mathrm{G}$ & $\Omega$ & Lake Red & Violet & \begin{tabular}{l|l}
+ \\
\end{tabular} & $\mathrm{DA}$ & 2 & Mengurai Rakitan Bagian Tengah \\
\hline 92 & Memegang Rangka & 2 & $\mathrm{G}$ & $\Omega$ & Lake Red & Violet Heavy & 71 & $\mathrm{~A}$ & 2 & Merakit Bagian Tengah \\
\hline 93 & Memegang Rangka & 6 & $\mathrm{G}$ & $\Omega$ & Lake Red & Violet Heavy & 11 & A & 6 & Merakit Bagian Tengah \\
\hline 94 & Memegang Rangka & 1 & $\mathrm{G}$ & $\Omega$ & Lake Red & Blue & 9 & $\mathrm{P}$ & 1 & Mengarahkan Roda \\
\hline 95 & Memegang Rangka & 2 & $\mathrm{G}$ & $\Omega$ & Lake Red & Gray & $\longrightarrow$ & SI & 2 & Memilih Roda Depan Kanan \\
\hline 96 & Memegang Rangka & 1 & $\mathrm{G}$ & $\Omega$ & Lake Red & \begin{tabular}{|l|} 
Violet Heavy \\
\end{tabular} & 7 & $\mathrm{~A}$ & 1 & Merakit Roda Depan Kanan \\
\hline 97 & Memegang Rangka & 1 & $\mathrm{G}$ & $\Omega$ & Lake Red & Gray & $\longrightarrow$ & SI & 1 & Memilih Roda Depan Kiri \\
\hline
\end{tabular}


Tabel 3.1 Data Hasil Pengamatan Material Dengan Peletakan Tidak Beraturan (Lanjutan...)

\begin{tabular}{|c|c|c|c|c|c|c|c|c|c|c|}
\hline \multicolumn{11}{|c|}{ Peta Tangan Kiri Dan Tangan Kanan } \\
\hline \multirow{3}{*}{\multicolumn{2}{|c|}{$\begin{array}{l}\text { Pekerjaan } \\
\text { Nomor Peta } \\
\text { Departemen }\end{array}$}} & \multirow{3}{*}{\multicolumn{4}{|c|}{$\begin{array}{l}\text { Merakit Lego Mobil } \\
01122018 \\
\text { Teknik Industri }\end{array}$}} & \multirow{3}{*}{\multicolumn{3}{|c|}{ Di Periksa Oleh }} & \multirow{3}{*}{\multicolumn{2}{|c|}{ Boy Isma Putra, ST., MM }} \\
\hline & & & & & & & & & & \\
\hline & & & & & & & & & & \\
\hline No. & Tangan Kiri & $\begin{array}{l}\text { Waktu } \\
\text { (detik) }\end{array}$ & $\begin{array}{c}\text { Lambang } \\
\text { Huruf }\end{array}$ & $\begin{array}{c}\text { Lambang } \\
\text { Gambar }\end{array}$ & $\begin{array}{c}\text { Lambang } \\
\text { Warna }\end{array}$ & $\begin{array}{l}\text { Lambang } \\
\text { Warna }\end{array}$ & $\begin{array}{c}\text { Lambang } \\
\text { Gambar }\end{array}$ & $\begin{array}{c}\text { Lambang } \\
\text { Huruf }\end{array}$ & $\begin{array}{l}\text { Waktu } \\
\text { (detik) }\end{array}$ & Tangan Kanan \\
\hline 98 & Memegang Rangka & 1 & $\mathrm{G}$ & $\Omega$ & Lake Red & Violet Heavy & $\mp$ & $\mathrm{A}$ & 1 & Merakit Roda Depan Kiri \\
\hline 99 & Memegang Rangka & 1 & $\mathrm{G}$ & $\Omega$ & Lake Red & Gray & $\longrightarrow$ & SI & 1 & Memilih Roda Belakang Kanan \\
\hline 100 & Memegang Rangka & 2 & $\mathrm{G}$ & $\Omega$ & Lake Red & Violet Heavy & $\mp$ & A & 2 & Merakit Roda Belakang Kanan \\
\hline 101 & Memegang Rangka & 1 & G & $\Omega$ & Lake Red & Gray & $\longrightarrow$ & SI & 1 & Memilih Roda Belakang Kiri \\
\hline 102 & Memegang Rangka & 2 & $\mathrm{G}$ & $\Omega$ & Lake Red & Violet Heavy & $\mp 1$ & $\mathrm{~A}$ & 2 & Merakit Roda Belakang Kiri \\
\hline 103 & Menaruh Lego Mobil & 2 & $\mathrm{RL}$ & $\infty$ & Carmine Red & Carmine Red & $\infty$ & RL & 2 & Menaruh Lego Mobil \\
\hline & Total & $239 "$ & 103 & & & & & 103 & $239 "$ & Total \\
\hline
\end{tabular}

Dapat disimpulkan dari tabel data merakit lego dengan peletakkan beraturan didapat 103 gerakan dengan waktu tiap siklus 239 detik, jumlah komponen tiap siklus 1 unit dan waktu untuk membuat satu komponen 239 detik. 


\subsection{Data Hasil Pengamatan Material Dengan Peletakan Beraturan}

Adapun data hasil pengamatan material dengan peletakan beraturan tersebut dapat dilihat pada tabel

\section{2 sebagai berikut :}

\section{Tabel 3.2 Data Hasil Pengamatan Material Dengan Peletakan Beraturan}

\begin{tabular}{|c|c|c|c|c|c|c|c|c|c|c|}
\hline \multicolumn{11}{|c|}{ Peta Tangan Kiri Dan Tangan Kanan } \\
\hline \multirow{3}{*}{\multicolumn{2}{|c|}{$\begin{array}{l}\text { Pekerjaan } \\
\text { Nomor Peta } \\
\text { Departemen }\end{array}$}} & \multirow{3}{*}{\multicolumn{4}{|c|}{$\begin{array}{l}\text { : Merakit Lego Mobil } \\
\text { : } 02122018 \\
\text { : Teknik Industri }\end{array}$}} & \multirow{3}{*}{\multicolumn{3}{|c|}{ Di Periksa Oleh }} & \multirow{3}{*}{\multicolumn{2}{|c|}{ : Boy Isma Putra, ST., MM }} \\
\hline & & & & & & & & & & \\
\hline & & & & & & & & & & \\
\hline No. & Tangan Kiri & $\begin{array}{l}\text { Waktu } \\
\text { (detik) }\end{array}$ & $\begin{array}{c}\text { Lambang } \\
\text { Huruf }\end{array}$ & $\begin{array}{c}\text { Lambang } \\
\text { Gambar }\end{array}$ & $\begin{array}{c}\text { Lambang } \\
\text { Warna }\end{array}$ & $\begin{array}{c}\text { Lambang } \\
\text { Warna }\end{array}$ & $\begin{array}{c}\text { Lambang } \\
\text { Gambar }\end{array}$ & $\begin{array}{c}\text { Lambang } \\
\text { Huruf }\end{array}$ & $\begin{array}{l}\text { Waktu } \\
\text { (detik) }\end{array}$ & Tangan Kanan \\
\hline 1 & Mengambil Dasar Rangka & 1 & $\mathrm{RE}$ & $v^{2}$ & Olive Green & Gray & $\longrightarrow$ & SI & 1 & Memilih Bagian Bawah \\
\hline 2 & Memegang Dasar Rangka & 1 & $\mathrm{G}$ & $\Omega$ & Lake Red & Violet Heavy & \pm 1 & $\mathrm{~A}$ & 1 & Merakit Bagian Bawah \\
\hline 3 & Memegang Dasar Rangka & 1 & $\mathrm{G}$ & $\Omega$ & Lake Red & Gray & $\longrightarrow$ & SI & 1 & Memilih Bagian Bawah \\
\hline 4 & Memegang Dasar Rangka & 3 & $\mathrm{G}$ & $\Omega$ & Lake Red & Violet Heavy & $\mp$ & $\mathrm{A}$ & 3 & Merakit Bagian Bawah \\
\hline 5 & Memegang Dasar Rangka & 1 & $\mathrm{G}$ & $\Omega$ & Lake Red & Gray & $\longrightarrow$ & SI & 1 & Memilih Bagian Bawah \\
\hline 6 & Memegang Dasar Rangka & 5 & $\mathrm{G}$ & $\Omega$ & Lake Red & Violet Heavy & 71 & $\mathrm{~A}$ & 5 & Merakit Bagian Bawah \\
\hline 7 & Memilih Bagian Bawah & 1 & SI & $\longrightarrow$ & Gray & Lake Red & $\Omega$ & $\mathrm{G}$ & 1 & Memegang Dasar Rangka \\
\hline 8 & Merakit Bagian Bawah & 2 & $\mathrm{~A}$ & $\mp$ & Violet Heavy & Lake Red & $\Omega$ & $\mathrm{G}$ & 2 & Memegang Dasar Rangka \\
\hline 9 & Memegang Dasar Rangka & 1 & $\mathrm{G}$ & $\Omega$ & Lake Red & Gray & $\longrightarrow$ & SI & 1 & Memilih Bagian Bawah \\
\hline 10 & Memegang Dasar Rangka & 3 & $\mathrm{G}$ & $\Omega$ & Lake Red & Violet Heavy & $\mp$ & $\mathrm{A}$ & 3 & Merakit Bagian Bawah \\
\hline 11 & Menaruh Rangka & 3 & RL & 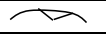 & Carmine Red & Gray & $\longrightarrow$ & SI & 3 & Memilih Bagian Depan \\
\hline 12 & Memegang Bagian Depan & 2 & $\mathrm{G}$ & $\Omega$ & Lake Red & Gray & $\longrightarrow$ & SI & 2 & Memilih Bagian Depan \\
\hline 13 & Memegang Bagian Depan & 2 & $\mathrm{G}$ & $\Omega$ & Lake Red & Violet Heavy & 干 & $\mathrm{A}$ & 2 & Merakit Bagian Depan \\
\hline 14 & Memegang Bagian Depan & 1 & $\mathrm{G}$ & $\Omega$ & Lake Red & Gray & $\longrightarrow$ & SI & 1 & Memilih Bagian Depan \\
\hline 15 & Memegang Bagian Depan & 2 & $\mathrm{G}$ & $\Omega$ & Lake Red & Violet Heavy & $\mp$ & $\mathrm{A}$ & 2 & Merakit Bagian Depan \\
\hline 16 & Memegang Bagian Depan & 1 & $\mathrm{G}$ & $\Omega$ & Lake Red & Gray & $\longrightarrow$ & SI & 1 & Memilih Bagian Depan \\
\hline 17 & Memegang Bagian Depan & 2 & $\mathrm{G}$ & $\Omega$ & Lake Red & Violet Heavy & $7+$ & $\mathrm{A}$ & 2 & Merakit Bagian Depan \\
\hline 18 & Memegang Bagian Depan & 1 & $\mathrm{G}$ & $\Omega$ & Lake Red & \begin{tabular}{|l|} 
Gray \\
\end{tabular} & $\longrightarrow$ & SI & 1 & Memilih Bagian Depan \\
\hline 19 & Memegang Bagian Depan & 3 & $\mathrm{G}$ & $\Omega$ & Lake Red & Violet Heavy & 7 & $\mathrm{~A}$ & 3 & Merakit Bagian Depan \\
\hline 20 & Mengambil Rangka & 4 & RE & $\checkmark$ & Olive Green & Lake Red & $\Omega$ & $\mathrm{G}$ & 4 & Memegang Bagian Depan \\
\hline 21 & Memegang Rangka & 3 & $\mathrm{G}$ & $\Omega$ & Lake Red & Violet Heavy & 11 & A & 3 & Merakit Bagian Depan \\
\hline
\end{tabular}




\begin{tabular}{|c|c|c|c|c|c|c|c|c|c|c|}
\hline \multicolumn{11}{|c|}{ Peta Tangan Kiri Dan Tangan Kanan } \\
\hline \multicolumn{2}{|c|}{$\begin{array}{l}\text { Pekerjaan } \\
\text { Nomor Peta } \\
\text { Departemen }\end{array}$} & \multicolumn{4}{|c|}{$\begin{array}{l}\text { : Merakit Lego Mobil } \\
: 02122018 \\
\text { : Teknik Industri }\end{array}$} & \multicolumn{3}{|c|}{ Di Periksa Oleh } & \multicolumn{2}{|c|}{ Boy Isma Putra, ST., MM } \\
\hline No. & Tangan Kiri & $\begin{array}{l}\text { Waktu } \\
\text { (detik) }\end{array}$ & $\begin{array}{c}\text { Lambang } \\
\text { Huruf }\end{array}$ & $\begin{array}{c}\text { Lambang } \\
\text { Gambar }\end{array}$ & $\begin{array}{c}\text { Lambang } \\
\text { Warna }\end{array}$ & $\begin{array}{c}\text { Lambang } \\
\text { Warna }\end{array}$ & $\begin{array}{c}\text { Lambang } \\
\text { Gambar }\end{array}$ & $\begin{array}{c}\text { Lambang } \\
\text { Huruf }\end{array}$ & $\begin{array}{l}\text { Waktu } \\
\text { (detik) }\end{array}$ & Tangan Kanan \\
\hline 22 & Menaruh Rangka & 3 & $\mathrm{RL}$ & 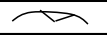 & Carmine Red & Gray & $\longrightarrow$ & SI & 3 & Memilih Bagian Depan \\
\hline 23 & Memilih Bagian Samping Kanan & 2 & SI & $\longrightarrow$ & Gray & Lake Red & $\Omega$ & $\mathrm{G}$ & 2 & Memegang Bagian Samping Kanan \\
\hline 24 & Memegang Bagian Samping Kanan & 3 & $\mathrm{G}$ & $\Omega$ & Lake Red & Violet Heavy & +1 & A & 3 & Merakit Bagian Samping Kanan \\
\hline 25 & Menaruh Bagian Samping Kanan & 1 & RL & 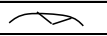 & Carmine Red & Gray & $\longrightarrow$ & SI & 1 & Memilih Bagian Samping Kiri \\
\hline 26 & Memilih Bagian Samping Kiri & 1 & SI & $\longrightarrow$ & Gray & Gray & $\longrightarrow$ & SI & 1 & Memilih Bagian Samping Kiri \\
\hline 27 & Memegang Bagian Samping Kiri & 1 & $\mathrm{G}$ & $\Omega$ & Lake Red & Violet Heavy & 11 & $\mathrm{~A}$ & 1 & Merakit Bagian Samping Kiri \\
\hline 28 & Menaruh Bagian Samping Kiri & 1 & RL & $\longrightarrow$ & Carmine Red & Brown & $\beta$ & $\mathrm{Pn}$ & 1 & Merencanakan \\
\hline 29 & Merencanakan & 1 & $\mathrm{Pn}$ & $\beta$ & Brown & Brown & $\beta$ & $\mathrm{Pn}$ & 1 & Merencanakan \\
\hline 30 & Mengambil Rangka & 1 & $\mathrm{RE}$ & $v^{2}$ & Olive Green & Olive Green & $v^{2}$ & $\mathrm{RE}$ & 1 & Mengambil Bagian Samping Kanan \\
\hline 31 & Memegang Rangka & 2 & $\mathrm{G}$ & $\Omega$ & Lake Red & Violet Heavy & 7 & $\mathrm{~A}$ & 2 & Merakit Bagian Samping Kanan \\
\hline 32 & Mengambil Bagian Samping Kiri & 1 & $\mathrm{RE}$ & $\gamma^{2}$ & Olive Green & Lake Red & $\Omega$ & $\mathrm{G}$ & 1 & Memegang Rangka \\
\hline 33 & Merakit Bagian Samping Kiri & 2 & $\mathrm{~A}$ & 71 & Violet Heavy & Lake Red & $\Omega$ & $\mathrm{G}$ & 2 & Memegang Rangka \\
\hline 34 & Menaruh Rangka & 2 & RL & 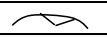 & Carmine Red & Brown & $\beta$ & $\mathrm{Pn}$ & 2 & Merencanakan \\
\hline 35 & Istirahat & 2 & $\mathrm{R}$ & $\overline{\mathrm{E}}$ & Orange & Gray & $\longrightarrow$ & SI & 2 & Memilih Bagian Belakang \\
\hline 36 & Memegang Bagian Belakang & 1 & $\mathrm{G}$ & $\Omega$ & Lake Red & Gray & $\longrightarrow$ & SI & 1 & Memilih Bagian Belakang \\
\hline 37 & Memegang Bagian Belakang & 1 & $\mathrm{G}$ & $\Omega$ & Lake Red & Violet Heavy & 7 & $\mathrm{~A}$ & 1 & Merakit Bagian Belakang \\
\hline 38 & Memegang Bagian Belakang & 1 & $\mathrm{G}$ & $\Omega$ & Lake Red & Gray & $\longrightarrow$ & SI & 1 & Memilih Bagian Belakang \\
\hline 39 & Memegang Bagian Belakang & 2 & $\mathrm{G}$ & $\Omega$ & Lake Red & Violet Heavy & 11 & $\mathrm{~A}$ & 2 & Merakit Bagian Belakang \\
\hline 40 & Memegang Bagian Belakang & 1 & $\mathrm{G}$ & $\Omega$ & Lake Red & Gray & $\longrightarrow$ & SI & 1 & Memilih Bagian Belakang \\
\hline 41 & Memegang Bagian Belakang & 4 & $\mathrm{G}$ & $\Omega$ & Lake Red & Violet Heavy & 11 & $\mathrm{~A}$ & 4 & Merakit Bagian Belakang \\
\hline 42 & Mengambil Rangka & 1 & $\mathrm{RE}$ & $\gamma^{\prime}$ & Olive Green & Lake Red & $\Omega$ & $\mathrm{G}$ & 1 & Memegang Bagian Belakang \\
\hline 43 & Memegang Rangka & 2 & $\mathrm{G}$ & $\Omega$ & Lake Red & Violet Heavy & 干1 & $\mathrm{A}$ & 2 & Merakit Bagian Belakang \\
\hline 44 & Memegang Rangka & 5 & $\mathrm{G}$ & $\Omega$ & Lake Red & Gray & $\longrightarrow$ & SI & 5 & Memilih Bagian Tengah \\
\hline 45 & Memegang Rangka & 3 & $\mathrm{G}$ & $\Omega$ & Lake Red & Violet Heavy & 71 & $\mathrm{~A}$ & 3 & Merakit Bagian Tengah \\
\hline
\end{tabular}

Tabel 3.2 Data Hasil Pengamatan Material Dengan Peletakan Beraturan (Lanjutan...) 


\begin{tabular}{|c|c|c|c|c|c|c|c|c|c|c|}
\hline \multirow{4}{*}{\multicolumn{2}{|c|}{$\begin{array}{l}\text { Pekerjaan } \\
\text { Nomor Peta } \\
\text { Departemen }\end{array}$}} & \multicolumn{7}{|c|}{ Peta Tangan Kiri Dan Tangan Kanan } & \multirow{4}{*}{\multicolumn{2}{|c|}{ : Boy Isma Put }} \\
\hline & & \multirow{3}{*}{\multicolumn{4}{|c|}{$\begin{array}{l}\text { : Merakit Lego Mobil } \\
02122018 \\
: \text { Teknik Industri }\end{array}$}} & \multirow{3}{*}{\multicolumn{3}{|c|}{ Di Periksa Oleh }} & & \\
\hline & & & & & & & & & & \\
\hline & & & & & & & & & & \\
\hline No. & Tangan Kiri & $\begin{array}{l}\text { Waktu } \\
\text { (detik) }\end{array}$ & $\begin{array}{c}\text { Lambang } \\
\text { Huruf }\end{array}$ & $\begin{array}{c}\text { Lambang } \\
\text { Gambar }\end{array}$ & $\begin{array}{c}\text { Lambang } \\
\text { Warna }\end{array}$ & $\begin{array}{c}\text { Lambang } \\
\text { Warna }\end{array}$ & $\begin{array}{c}\text { Lambang } \\
\text { Gambar }\end{array}$ & $\begin{array}{c}\text { Lambang } \\
\text { Huruf }\end{array}$ & $\begin{array}{l}\text { Waktu } \\
\text { (detik) }\end{array}$ & \\
\hline 46 & Menaruh Rangka & 2 & $\mathrm{RL}$ & $\longrightarrow$ & Carmine Red & Brown & $\beta$ & Pn & 2 & Mer \\
\hline 47 & Memilih Bagian Belakang & 2 & SI & $\longrightarrow$ & Gray & Gray & $\longrightarrow$ & SI & 2 & Men \\
\hline 48 & Merakit Bagian Belakang & 1 & A & $\mp 1$ & Violet Heavy & Lake Red & $\Omega$ & $\mathrm{G}$ & 1 & Mer \\
\hline 49 & Memilih Bagian Belakang & 1 & SI & $\longrightarrow$ & Gray & Lake Red & $\Omega$ & $\mathrm{G}$ & 1 & Mer \\
\hline 50 & Merakit Bagian Belakang & 2 & A & $\mp 1$ & Violet Heavy & Lake Red & $\Omega$ & G & 2 & Mer \\
\hline 51 & Memegang Rangka & 1 & G & $\Omega$ & Lake Red & Lake Red & $\Omega$ & G & 1 & Mer \\
\hline 52 & Memegang Rangka & 2 & $\mathrm{G}$ & $\Omega$ & Lake Red & Violet Heavy & 71 & A & 2 & Mer \\
\hline 53 & Memegang Rangka & 3 & $\mathrm{G}$ & $\Omega$ & Lake Red & Gray & $\longrightarrow$ & $\mathrm{SI}$ & 3 & Mer \\
\hline 54 & Memegang Rangka & 4 & $\mathrm{G}$ & $\Omega$ & Lake Red & Violet Heavy & 11 & A & 4 & $\mathrm{Me}$ \\
\hline 55 & Memegang Body Mobil & 3 & $\mathrm{G}$ & $\Omega$ & Lake Red & Gray & $\longrightarrow$ & SI & 3 & $\mathrm{Me}$ \\
\hline 56 & Memegang Body Mobil & 3 & $\mathrm{G}$ & $\Omega$ & Lake Red & Violet Heavy & 71 & A & 3 & Mer \\
\hline 57 & Memegang Body Mobil & 3 & G & $\Omega$ & Lake Red & Gray & $\longrightarrow$ & SI & 3 & Mer \\
\hline 58 & Memegang Body Mobil & 2 & G & $\Omega$ & Lake Red & Violet Heavy & 木1 & A & 2 & Mer \\
\hline 59 & Memegang Body Mobil & 2 & G & $\Omega$ & Lake Red & Gray & $\longrightarrow$ & SI & 2 & Mer \\
\hline 60 & Memegang Body Mobil & 2 & G & $\Omega$ & Lake Red & Violet Heavy & 71 & A & 2 & Mer \\
\hline 61 & Memegang Body Mobil & 1 & G & $\Omega$ & Lake Red & Gray & $\longrightarrow$ & SI & 1 & Mer \\
\hline 62 & Memegang Body Mobil & 2 & $\mathrm{G}$ & $\Omega$ & Lake Red & Violet Heavy & 71 & $\mathrm{~A}$ & 2 & $\mathrm{Me}$ \\
\hline 63 & Memegang Body Mobil & 3 & $\mathrm{G}$ & $\Omega$ & Lake Red & Gray & $\longrightarrow$ & SI & 3 & $\mathrm{Me}$ \\
\hline 64 & Memegang Body Mobil & 2 & $\mathrm{G}$ & $\Omega$ & Lake Red & Violet Heavy & 71 & $\mathrm{~A}$ & 2 & Mer \\
\hline 65 & Memegang Body Mobil & 1 & $\mathrm{G}$ & $\Omega$ & Lake Red & Gray & $\longrightarrow$ & SI ${ }^{18}$ & 1 & Men \\
\hline 66 & Memegang Body Mobil & 1 & $\mathrm{G}$ & $\Omega$ & Lake Red & Violet Heavy & 11 & A & 1 & Mer \\
\hline 67 & Memegang Body Mobil & 1 & $\mathrm{G}$ & $\Omega$ & Lake Red & Gray & $\longrightarrow$ & SI & 1 & Men \\
\hline 68 & Memegang Body Mobil & 2 & G & $\Omega$ & Lake Red & Violet Heavy & 11 & A & 2 & Mer \\
\hline 69 & Memegang Bodv Mobil & 1 & $\mathrm{G}$ & $\Omega$ & Lake Red & Grav & $\longrightarrow$ & SI & 1 & \\
\hline
\end{tabular}


Tabel 3.2 Data Hasil Pengamatan Material Dengan Peletakan Beraturan (Lanjutan...)

\begin{tabular}{|c|c|c|c|c|c|c|c|c|c|c|}
\hline \multirow{4}{*}{\multicolumn{2}{|c|}{$\begin{array}{l}\text { Pekerjaan } \\
\text { Nomor Peta } \\
\text { Departemen }\end{array}$}} & \multicolumn{7}{|c|}{ Peta Tangan Kiri Dan Tangan Kanan } & \multirow{4}{*}{\multicolumn{2}{|c|}{ : Boy Isma Put }} \\
\hline & & \multirow{3}{*}{\multicolumn{4}{|c|}{$\begin{array}{l}\text { Merakit Lego Mobil } \\
\text { : } 02122018 \\
\text { : Teknik Industri }\end{array}$}} & \multirow{3}{*}{\multicolumn{3}{|c|}{ Di Periksa Oleh }} & & \\
\hline & & & & & & & & & & \\
\hline & & & & & & & & & & \\
\hline No. & Tangan Kiri & $\begin{array}{l}\text { Waktu } \\
\text { (detik) }\end{array}$ & $\begin{array}{c}\text { Lambang } \\
\text { Huruf } \\
\end{array}$ & $\begin{array}{c}\text { Lambang } \\
\text { Gambar }\end{array}$ & $\begin{array}{c}\text { Lambang } \\
\text { Warna }\end{array}$ & $\begin{array}{c}\text { Lambang } \\
\text { Warna }\end{array}$ & $\begin{array}{c}\text { Lambang } \\
\text { Gambar }\end{array}$ & $\begin{array}{c}\text { Lambang } \\
\text { Huruf }\end{array}$ & $\begin{array}{l}\text { Waktu } \\
\text { (detik) }\end{array}$ & \\
\hline 70 & Memegang Body Mobil & 1 & $\mathrm{G}$ & $\Omega$ & Lake Red & Violet Heavy & 干1 & $\mathrm{A}$ & 1 & Mer \\
\hline 71 & Memegang Body Mobil & 1 & G & $\Omega$ & Lake Red & Gray & $\longrightarrow$ & SI & 1 & Men \\
\hline 72 & Memegang Body Mobil & 2 & G & $\Omega$ & Lake Red & Violet Heavy & 11 & A & 2 & Mer \\
\hline 73 & Memegang Body Mobil & 1 & $\mathrm{G}$ & $\Omega$ & Lake Red & Gray & $\longrightarrow$ & SI & 1 & Mer \\
\hline 74 & Memegang Body Mobil & 1 & G & $\Omega$ & Lake Red & Violet Heavy & 7 & A & 1 & Mer \\
\hline 75 & Mengarahkan Body Mobil & 1 & $\mathrm{P}$ & 9 & Blue & Blue & 9 & $\mathrm{P}$ & 1 & Men \\
\hline 76 & Memegang Body Mobil & 1 & $\mathrm{G}$ & $\Omega$ & Lake Red & Gray & $\longrightarrow$ & SI & 1 & Men \\
\hline 77 & Memegang Body Mobil & 2 & $\mathrm{G}$ & $\Omega$ & Lake Red & Violet Heavy & 11 & $\mathrm{~A}$ & 2 & Mer \\
\hline 78 & Menaruh Lego Mobil & 1 & RL & $\infty$ & Carmine Red & Carmine Red & $\longrightarrow$ & $\mathrm{RL}$ & 1 & Men \\
\hline & $\begin{array}{r}\text { Total } \\
\end{array}$ & $145^{\prime \prime}$ & 78 & & & & & 78 & $145^{\prime \prime}$ & \\
\hline
\end{tabular}

dengan waktu tiap siklus 145 detik, jumlah komponen tiap siklus 1 unit dan waktu untuk membuat satu komponen

detik. 


\subsection{Perakitan Mobil Lego Secara Tidak Beraturan}

Berikut ini adalah kegiatan tangan kiri dan tangan kanan pada perakitan mobil lego secaratidak beraturan.

\subsubsection{Hasil Analisa Peta Tangan Kiri}

Adapun hasilnya dapat dilihat pada tabel 4.1 sebagai berikut :

Tabel 4.1 Perakitan Material Tidak Beraturan Dengan Tangan Kiri

\begin{tabular}{|c|c|c|c|c|c|c|}
\hline No & Jenis Kegiatan & Simbol & Lambang & Warna & $\begin{array}{l}\text { Jumlah } \\
\text { íegiatan }\end{array}$ & Waktu \\
\hline 1 & Merakit Komponen & A & 7 & $\begin{array}{l}\text { Violet } \\
\text { Heavy }\end{array}$ & 1 & 5 \\
\hline 2 & $\begin{array}{l}\text { Memegang } \\
\text { Rangkaian }\end{array}$ & G & & Lake Red & 79 & 178 \\
\hline 3 & $\begin{array}{l}\text { Memeriksa } \\
\text { Rangkaian }\end{array}$ & 1 & & $\begin{array}{l}\text { Burn } \\
\text { Ochre }\end{array}$ & 1 & 2 \\
\hline 4 & $\begin{array}{l}\text { Mengarahkan } \\
\text { Rangkaian }\end{array}$ & $P$ & & Blue & 3 & 4 \\
\hline 5 & $\begin{array}{l}\text { Merencanakan } \\
\text { Rangkaian }\end{array}$ & $\mathrm{Pn}$ & & Brown & 1 & 11 \\
\hline 6 & Istirahat & $\mathrm{R}$ & & Orange & 4 & 9 \\
\hline 7 & $\begin{array}{l}\text { Mengambil } \\
\text { Rangkaian }\end{array}$ & RE & & $\begin{array}{l}\text { Olive } \\
\text { Green }\end{array}$ & 6 & 13 \\
\hline 8 & MenaruhRangkaian & $\mathrm{RL}$ & & $\begin{array}{c}\text { Carmine } \\
\text { Red }\end{array}$ & 6 & 13 \\
\hline 9 & MencariKomponen & Sh & & Black & 1 & 1 \\
\hline 10 & $\begin{array}{l}\text { Memilih } \\
\text { Komponen }\end{array}$ & SI & & Gray & 1 & 3 \\
\hline & \multicolumn{4}{|c|}{ Jumlah } & 103 & 239 \\
\hline
\end{tabular}




\subsubsection{Hasil Analisa Peta Tangan Kanan}

Adapun hasilnya dapat dilihat pada tabel 4.2 sebagai berikut :

Tabel 4.2 Perakitan Material Tidak Beraturan Dengan Tangan Kanan

\begin{tabular}{|c|c|c|c|c|c|c|}
\hline No & Jenis Kegiatan & Simbol & Lambang & Warna & $\begin{array}{l}\text { Jumlah } \\
\text { iegiatan }\end{array}$ & Waktu \\
\hline 1 & Merakit Komponen & $A$ & 耳 & $\begin{array}{l}\text { Violet } \\
\text { Heavy }\end{array}$ & 37 & 94 \\
\hline 2 & Mengurai Rakitan & DA & & Violet & 3 & 6 \\
\hline 3 & $\begin{array}{l}\text { Memegang } \\
\text { Rangkaian }\end{array}$ & G & & Lake Red & 5 & 13 \\
\hline 4 & $\begin{array}{l}\text { Memeriksa } \\
\text { Rangkaian }\end{array}$ & I & & $\begin{array}{l}\text { Burn } \\
\text { Ochre }\end{array}$ & 1 & 2 \\
\hline 5 & $\begin{array}{l}\text { Mengarahkan } \\
\text { Rangkaian } \\
\end{array}$ & $P$ & & Blue & 2 & 3 \\
\hline 6 & $\begin{array}{l}\text { Merencanakan } \\
\text { Rangkaian }\end{array}$ & $\mathrm{Pn}$ & & Brown & 7 & 31 \\
\hline 7 & Istirahat & $R$ & & Orange & 4 & 7 \\
\hline 8 & $\begin{array}{l}\text { Mengambil } \\
\text { Rangkaian }\end{array}$ & $\mathrm{RE}$ & & $\begin{array}{l}\text { Olive } \\
\text { Green }\end{array}$ & 1 & 2 \\
\hline 9 & MenaruhRangkaian & $R L$ & & $\begin{array}{c}\text { Carmine } \\
\text { Red }\end{array}$ & 3 & 6 \\
\hline 10 & MencariKomponen & Sh & & Black & 6 & 14 \\
\hline 11 & $\begin{array}{l}\text { Memilih } \\
\text { Komponen }\end{array}$ & $\mathrm{SI}$ & & Gray & 34 & 61 \\
\hline & \multicolumn{4}{|c|}{ Jumlah } & 103 & 239 \\
\hline
\end{tabular}

\subsection{Perakitan Mobil Lego Secara Beraturan}

Berikut ini adalah kegiatan tangan kiri dan tangan kanan pada perakitan mobil lego secara beraturan. 


\subsubsection{Hasil Analisa Peta Tangan Kiri}

Adapun hasilnya dapat dilihat pada tabel 4.3 sebagai berikut :

Tabel 4.3 Perakitan Material Beraturan Dengan Tangan Kiri

\begin{tabular}{|c|l|c|c|c|c|c|}
\hline No & Jenis Kegiatan & Simbol & Lambang & Warna & Jml Keg & Waktu \\
\hline 1 & $\begin{array}{l}\text { Merakit } \\
\text { Komponen }\end{array}$ & $\mathrm{A}$ & + & $\begin{array}{l}\text { Violet } \\
\text { Heavy }\end{array}$ & 4 & 7 \\
\hline 2 & $\begin{array}{l}\text { Memegang } \\
\text { Rangkaian }\end{array}$ & $\mathrm{G}$ & $\Omega$ & Lake Red & 54 & 106 \\
\hline 3 & $\begin{array}{l}\text { Mengarahkan } \\
\text { Rangkaian }\end{array}$ & $\mathrm{P}$ & 9 & Blue & 1 & 1 \\
\hline 4 & $\begin{array}{l}\text { Merencanakan } \\
\text { Rangkaian }\end{array}$ & $\mathrm{Pn}$ & $\mathrm{Q}$ & Brown & 1 & 1 \\
\hline
\end{tabular}

Tabel 4.3 Perakitan Material Beraturan Dengan Tangan Kiri(Lanjutan...)

\begin{tabular}{|c|l|c|c|c|c|c|}
\hline No & Jenis Kegiatan & Simbol & Lambang & Warna & Jml Keg & Waktu \\
\hline 5 & Istirahat & $\mathrm{R}$ & $\mathrm{R}$ & Orange & 1 & 2 \\
\hline 6 & $\begin{array}{l}\text { Mengambil } \\
\text { Rangkaian }\end{array}$ & $\mathrm{RE}$ & $\begin{array}{r}\text { Olive } \\
\text { Green }\end{array}$ & 5 & 8 \\
\hline 7 & MenaruhRangkaian & $\mathrm{RL}$ & $\longrightarrow$ & $\begin{array}{c}\text { Carmine } \\
\text { Red }\end{array}$ & 7 & 13 \\
\hline 8 & $\begin{array}{l}\text { Memilih } \\
\text { Komponen }\end{array}$ & $\mathrm{SI}$ & $\longrightarrow$ & Gray & 5 & 7 \\
\hline & \multicolumn{3}{|c|}{ Jumlah } & 78 & 145 \\
\hline
\end{tabular}




\subsubsection{Hasil Analisa Peta Tangan Kanan}

Adapun hasilnya dapat dilihat pada tabel 4.4 sebagai berikut :

Tabel 4.4 Perakitan Material Beraturan Dengan Tangan Kanan

\begin{tabular}{|c|c|c|c|c|c|c|}
\hline No & Jenis Kegiatan & Simbol & Lambang & Warna & $\mathrm{Iml} \mathrm{Keg}$ & Waktu \\
\hline 1 & Merakit Komponen & A & 71 & $\begin{array}{l}\text { Violet } \\
\text { Heavy }\end{array}$ & 30 & 68 \\
\hline 2 & $\begin{array}{l}\text { Memegang } \\
\text { Rangkaian }\end{array}$ & G & & Lake Red & 11 & 18 \\
\hline 3 & $\begin{array}{l}\text { Mengarahkan } \\
\text { Rangkaian }\end{array}$ & $P$ & & Blue & 1 & 1 \\
\hline 4 & $\begin{array}{l}\text { Merencanakan } \\
\text { Rangkaian }\end{array}$ & Pn & & Brown & 4 & 6 \\
\hline 5 & $\begin{array}{l}\text { Mengambil } \\
\text { Rangkaian }\end{array}$ & RE & & $\begin{array}{l}\text { Olive } \\
\text { Green }\end{array}$ & 1 & 1 \\
\hline 6 & MenaruhRangkaian & $\mathrm{RL}$ & & $\begin{array}{c}\text { Carmine } \\
\text { Red }\end{array}$ & 1 & 1 \\
\hline 7 & $\begin{array}{l}\text { Memilih } \\
\text { Komponen }\end{array}$ & $\mathrm{SI}$ & & Gray & 30 & 50 \\
\hline & \multicolumn{4}{|c|}{ Jumlah } & 78 & 145 \\
\hline
\end{tabular}

\subsection{Kesimpulan}

Dari praktikum perancangan sistem kerja dan ergonomi modul micromotion study dapat kita peroleh kesimpulan sebagai berikut:

1. Micromotion study merupakan metode yang digunakan dalam melakukan perbaikan kerja dengan menganalisa gerakangerakan yang dilakukan oleh pekerja. Tujuan micromotion 
study adalah memperbaiki metode kerja sehingga pekerjaan akan lebih efektif dan efisien.

2. Dalam praktikum micromotion study proses perakitan leggo, terdapat 7 gerakan elemen dasar yang dilakukan antara lain merakit, memegang, mengarahkan sementara, merencanakan, mengambil, meletakkan, dan memilih komponen.

3. Perbaikan yang dilakukan dalam perakitan leggo antara lain penempatan rangka leggo secara teratur sehingga gerakan memilih rangka leggo semakin mudah. Hal ini berpengaruh pada waktu yang diperlukan dalam waktu perakitan leggo.

4. Pada perakitan leggo dalam kondisi rangkaian tidak beraturan, perakitan 1 buah leggo memerlukan waktu 295 detik, sedangkan dalam kondisi perbaikan memerlukan waktu 145 detik. 


\section{DAFTAR PUSTAKA}

Adiputra, N.1998 Metodologi Ergonomi.Monograf yang diperbanyak oleh program Studi Ergonomi dan Fisiologi Kerja, Program Pascasarjana Universitas Udayana Denpasar.

American Conference of Govermenial Industrial Hygienists(ACGIH), 1995. Thresh-old Limit Values and Biological Exposure Indies. Cincinati. USA

Arif, Muhammad. 2016."Rancangan Teknik Industri". Sleman: CV BUDI UTAMA.

Astrand, P.O. \& Rodahl,K. 1977. Textbook of Work PhysiologyPhysiological Bases of Exercise. $2^{\text {nd }}$ edt. McGraw-Hill Book Company. USA.

Astuti, Rahmaniyah Dwi. Irwan Iftadi. 2016. "Analisis Dan Perancangan Sistem Kerja". Sleman: CV BUDI UTAMA.

Cahyawati, Nur, Amanda. Dkk. 2018."Analisis Pengukuran Kerja Dengan Menggunakan Metode Stopwatch Time Study". Malang. Universitas Brawijaya Malang. Vol. 3. 107.

Christensen, E.H.1991. Physiology of Work. Dalam: Parmeggiani, L. ed. Encyclopaedia of Occupational Healthand Safety, Third (revised) edt.ILO, Geneva: 1698-1700.

Darsini. 2014. "Penentuan Waktu Baku Produksi Kerupuk Rambak Ikan Laut "Sari Enak" Di Sukoharjo". Sukoharjo. Universitas 
Veteran Bangun Nusantara Sukoharjo. Fakultas Teknik. Program Studi Teknik Industri. Vol. 12. No. 2. Hal. 222-223.

Dewi,Luciana Triani. dkk. 2015. "Implementasi Prinsip Ekonomi Gerakan Untuk Pengaturan Tata Letak Fasilitas Kerja Pada Pemrosesan Batu Alam". Yogyakarta. Universitas Atma Jaya Yogyakarta. Fakultas Teknologi Industri. Program Studi Teknik Industri. Vol. 14. No. 2. Hal. 2.

Erliana, Cut Ita. 2015. "Analisa dan Pengukuran Kerja". Muara Batu: FAKULTAS TEKNIK UNIVERSITAS MALIKISSALEH.

Faritsy,Al, Ari Zaqi. Yohannes Anton Nugroho. 2017. "Pengukuran Lingkungan Kerja Fisik dan Operator Untuk Menentukan Waktu Istirahat Kerja". Yogyakarta. Universitas TeknologiYogyakarta. Fakultas Sains dan Teknologi. Jurusan Teknik Industri.Vol. 16. No. 2. Hal. $109-111$.

Grandjean,E. 1993.Fitting the Task to the Man, $4^{\text {th }}$ edt. Taylor \& Francisc Inc.Lodon.

Grantham, D. 1992. Occupational Health \& Safety. Guidebook for the WHSO. Merino Lithographies Moorooka Queensland. Australia.

Herjanto, Eddy. 2007. "Manajemen Operasi”. Jakarta: Grasindo.

Irzal. 2016. "Dasar - Dasar Keselamatan Dan Kesehatan Kerja". Jakarta: Kencana.

Jono. 2015. "Pengukuran Beban Kerja Tenaga Kerja Dengan Metode Work Sampling (Studi Kasus Di PT. XY Yogyakarta)". Yogyakarta. Universitas Widya Mataram Yogyakarta. Fakultas Teknik. Jurusan Teknik Industri. Vol. 13.No. 2.Hal 115-228.

Keputusan Menteri Tenaga Kerja, No.51:1999. Nilai Ambang Batas Faktor Fisika diTempatKerja. Jakarta

Konz, S. 1996. Physiology of Body Movement. Dalam: Battacharya, A. \& McGlothlin,J.D.eds. Occupational Ergonomic Marcel Dekker Inc. USA:47-61 
Kusumanto, Ismu. 2016. "Perbaikan Metode Kerja Untuk Meningkatkan Produktivitas Kerja Operator Pada Stasiun Pengemasan Di CV. Mie Sohun Ichlas". Pekanbaru. UIN Sultan Syarif Kasim Riau. Fakultas Sains dan Teknologi. Jurusan Teknik Industri. Vol. 2. No. 2. Hal. 4.

Lubis, Aswadi. 2015. "Lingkungan Kerja Yang Kondusif Dan FaktorFaktor Yang Mempengaruhinya".Padang Sidimpuan. IAIN Padang Sidimpuan. Fakultas Ekonomi Bisnis Islam. Vol. 3. No. 1. Hal. $42-43$.

Lumbantobing Hariman. dkk. 2018. "Analisis Gerakan Kerja Untuk Memperbaiki Metode Kerja Dan Efisiensi Waktu Pengerjaan Produk Menggunakan Metode Most (Studi Kasus PT. Infineon Technologies Batam)". Batam. Universitas Riau Kepulauan Batam. Fakultas teknik. Program Studi Teknik Industri. Vol. 6. No. 2. Hal. 2.

Manuaba, A. 2000. Ergonomi, Kesehatan dan Keselamatan Kerja. Dalam: Wignypspebrotro, S.\& Wiratno,S.E.,Eds. Proceediong Seminar Nasional Ergonomi. PT.Guna Wdya. Surabaya:1-4.

Maryana. Sri Meutia. 2015. "Perbaikan Metode Kerja Pada Bagian Produksi Dengan Menggunakan Man And Machine Chart". Aceh. Universitas Malikussaleh-Nanggroe Aceh Darussalam (NAD). Fakultas Teknik. Jurusan Teknik Industri. Vol. 02. No. 2. Hal. 16-18.

Norianggono, Yacinda Chresstela Prasidya. Dkk. 2014. "Pengaruh Lingkungan Kerja Fisik Dan Non Fisik Terhadap Kinerja Karyawan (Studi Pada Karyawan PT. Telkomsel Area III JawaBali Nusra Di Surabaya)". Malang. Universitas Brawijaya. Fakultas Ilmu Administrasi. Administrasi Bisnis. Vol. 8 no. 2. Hal. $56-57$. 
Prihantoro, Agung. 2015. " PeningkatanKinerja Sumber Daya Manusia Melalui Motivasi, Disiplin, Lingkungan Kerja dan Komitmen. Sleman: CV. Budi Utama

Purbasari, Annisa. Akhiri Joko Purnomo. 2019. "Penilaian Beban Fisik Pada Proses Assembly Manual Menggunakan Metode Fisiologis". Batam. Universitas Riau Kepulauan.Fakultas Teknik. Teknik Industri. Vol. 2, No. 1. Hal. 126.

Purnomo, Rochmat Aldy. 2017. "Analisis Statistik Ekonomi dan Bisnis dengan SPSS". Ponorogo: CV. Wade Grup.

Ridahl, K. 1989. The Physiology of Work. Taylor \& Francis Ltd. Grat Britain:15-99

Sokhibi, Akhmad. 2017. "Perancangan Kursi Ergonomis Untuk Memperbaiki Posisi Kerja Pada Proses Packaging Jenang Kudus". Kudus. Universitas Muria Kudus. Fakultas Teknik. Program Studi Teknik Industri. Vol. 3. No. 1. Hal. 63.

Suma'mur,P.P. 1982. Ergonomi Untuk Produktivitas Kerja. Yayasan Swabhawa Karya. Jakarta.

Suma'mur,P.P. 1984. Higene Perusahaan dan Kesehatan Kerja.Cet-4, Penerbit PT.Gunung Agung. Jakarta:82-92

Sutalaksana, Iftikar Z. 2016."Teknik Tata Cara Kerja Laboratorium Tata Cara Kerja Dan Ergonomi". Bandung: Institut Teknologi Bandung.

Veza, Okta. 2017. "Analisis Waktu Standar Pelayanan Dan Produktivitas Pegawai Menggunakan Metode Work Sampling". Batam. STT Ibnu Sina. Program Studi Teknik Informatika. Vol. 1.No. 1.Hal. 9-17.

Workplace Health andSafety (WHS) 1993. Code of Practice for Noise Management at Work. Australia. 
Wignjosoebroto, Sritomo. 2006. "Ergonomi Studi Gerak Dan Waktu". Surabaya: Guna Widya.

Wijaya, M. Angga. 2016. "Analisa Perbandingan Antropometri Bentuk Tubuh Mahasiswa Pekerja Galangan Kapal Dan Mahasiswa Pekerja Elektronika". Batam. Universitas Riau Kepulauan Batam. Program Studi Teknik Industri. Vol. 4.No. 2. 108-117. 


\section{BIODATA PENULIS}

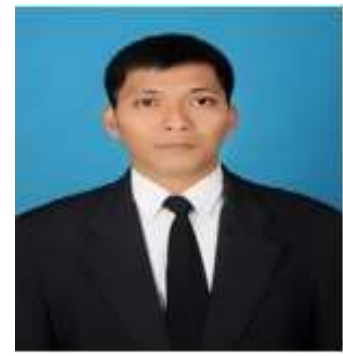

Boy Isma Putra, ST., MM.dilahirkan di Surabaya, 11 April 1974. Lulus Sarjana Teknik Industri Universitas Pembangunan Nasonal 'Veteran' Jawa Timur tahun 1998, melanjutkan studi S2 di Magister Manajemen Program Pascasarjana Universitas Muhammadiyah Malang lulus tahun 2004. Sejak tahun 1998 sampai sekarang, menjadi dosen tetap di prodi Teknik Industri Universitas Muhammadiyah Sidoarjo .

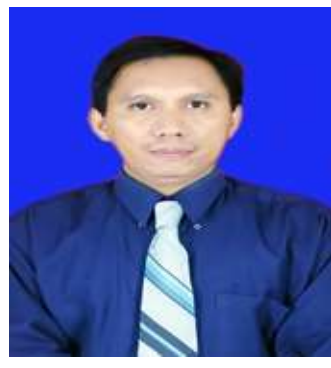

Ribangun Bamban Jakaria, ST.,MM lahir di Sidoharjo, 04 Mei 1976. Lulus Sarjana teknik Industri Universitas Muhammadiyah Sidoarjo tahun 2003, melanjutkan studi S2 di Magister Manajemen Program Pascasarjana Universitas Pembangunan Nasonal 'Veteran' Jawa Timur lulus tahun 2010. Saat ini sedang menempuh Program doktoral pada fakulty reka bentuk, inovasi dan teknologi Universitas Sultan Zainal Abidin (UNISZA) Kuala terengganu Malaysia. Karir pengajaran dimulai tahun 2013 di Fakultas Sain dan Teknologi Universitas Muhammadiyah Sidoarjo. Penulis terlibat dalam penelitian dan pengabdian kepada masyarakat baik didanai oleh Ristekdikti, institusi maupun dana mandiri tentang Desain Produk, Inovasi Teknologi, Sistem Informasi Dan Distribusi. 